\title{
A família Leguminosae na Serra de Baturité, Ceará, uma área de Floresta Atlântica no semiárido brasileiro'
}

\author{
The family Leguminosae in the Baturité mountain range, Ceará State, \\ an area of Atlantic Forest in the semi-arid region of Brazil
}

Jacira Rabelo Lima ${ }^{2,4}$ \& Vidal de Freitas Mansano ${ }^{2,3}$

\begin{abstract}
Resumo
A Serra de Baturité é um dos maiores remanescentes de Floresta Atlântica localizado em meio ao semiárido brasileiro. A área apresenta uma grande diversidade, sendo considerada de extrema importância biológica para a conservação. Foram realizadas coletas de Leguminosae entre fevereiro/2007 e fevereiro/2009 e a lista de espécies foi complementada com dados das coleções de herbários. As Leguminosae foram representadas por 56 gêneros e 132 espécies. A subfamília Papilionoideae contribuiu com maior riqueza de gêneros e espécies ( 31 e 58, respectivamente), seguida das subfamílias Mimosoideae (17 gêneros e 41 espécies) e Caesalpinioideae (oito gêneros e 33 espécies). Entre as especies estudadas na área, 55\% são árvores e arbustos. Os gêneros mais diversos na área foram: Mimosa L. (15), Senna Mill. (12), Desmodium Desv. (sete) e Chamaecrista Moench, Bauhinia L., Inga Mill. e Aeschynomene L. (seis cada).
\end{abstract}

Palavras-chave: diversidade, Fabaceae, floresta estacional e ombrófila.

\begin{abstract}
The Baturite mountain range is one of the largest remnants of Atlantic forest located in the the Brazilian semiarid region. The area presents a high diversity, being considered of extreme biological importance for the conservation. The species of family Leguminosae were collected from February/2007 to February/2009 and the species list was complemented with herbarium analysis. The Leguminosae was represented by 56 genera and 132 taxa. The subfamily Papilionoideae contributed with higher richness of genus and species ( 31 genera and 58 taxa) followed by Mimosoideae (17 genera and 41 taxa) and Caesalpinioideae (eight genera and 33 taxa). Among the species studied in the area, 55\% of them are trees and shrubs. The most diverse genera are Mimosa L. (15), Senna Mill. (12), Desmodium Desv. (seven) e Chamaecrista Moench, Bauhinia L., Inga Mill. and Aeschynomene L. (six each).
\end{abstract}

Key words: diversity, Fabaceae, seazonal and ombrophylous forest.

\section{Introdução}

A Floresta Atlântica nordestina estendia-se originalmente por uma área de $11.960 \mathrm{~km}^{2}$. No entanto, atualmente, apenas $19,4 \%$ desta área apresentam-se coberta por remanescentes florestais (Silva \& Casteleti 2005). Essas florestas são encontradas na forma de enclaves espalhados no interior da savana estépica (Silva \& Casteleti 2005) e são consideradas áreas de refúgio tanto para a flora como para a fauna por apresentarem clima mais úmido e frio do que a savana estépica localizada no seu entorno (Andrade-Lima 1982). Entre essas áreas de Floresta Atlântica, destaca-se a Serra de Baturité, no estado do Ceará.

A Serra de Baturité, cuja biota apresenta elementos tanto da floresta ombrófila densa

\footnotetext{
${ }^{1}$ Parte da tese de Doutorado da primeira autora, Escola Nacional de Botânica Tropical, Instituto de Pesquisas Jardim Botânico do Rio de Janeiro, Rio de Janeiro. ${ }^{2}$ Programa de Pós-Graduação em Botânica da Escola Nacional de Botânica Tropical. ${ }^{3}$ Instituto de Pesquisas Jardim Botânico do Rio de Janeiro, DIPEQ, R. Pacheco Leão 915, 22460-030, Rio de Janeiro, RJ, Brasil.

${ }^{4}$ Autor para correspondência: jacirarabelo@gmail.com
} 
atlântica como da floresta ombrófila densa amazônica (Araújo et al. 2006), é uma das serras mais extensas e uma das mais altas e úmidas do Ceará. Sua vegetação varia de acordo com a altitude e a vertente (barlavento/sotavento), sendo considerada uma área de extrema importância biológica para a conservação (MMA 2000). Apesar de toda diversidade biológica, poucos estudos foram realizados na Serra de Baturité com o objetivo de conhecer melhor sua diversidade. Os únicos estudos florísticos e fitossociológicos realizados nesta serra foram os de Figueiredo et al. (1990), Cavalcante et al. (2000) e Araújo et al. (2006). Segundo Araújo et al. (2006), Leguminosae destaca-se como uma das famílias mais diversas da área.

Leguminosae, ou Fabaceae, é uma das famílias botânica com maior riqueza de espécies, sendo superada apenas pelas Orchidaceae e Asteraceae (Lewis et al. 2005). É importante do ponto de vista econômico, principalmente para a alimentação, ficando atrás somente das Poaceae (Doyle \& Luckow 2003). Atualmente são conhecidos cerca de 727 gêneros e 19.325 espécies que estão subordinadas às subfamílias Caesalpinioideae, Mimosoideae e Papilionoideae (Lewis et al. 2005). A família está entre as de maior riqueza de espécies no semiárido brasileiro (Queiroz 1999), aparecendo com destaque em várias fitofisionomias.

Esse trabalho teve como objetivo realizar a sinopse das espécies da família Leguminosae ocorrentes na Serra de Baturité, Ceará, com a elaboração de chaves de identificação dos gêneros e espécies, comentários com caracteres diagnósticos, distribuição geográfica das espécies e ilustrações botânicas de, pelo menos, uma espécie por gênero.

\section{Material e Métodos}

Área de estudo

A Serra de Baturité $\left(4^{\circ}\right.$ a $4^{\circ} 30^{\prime} \mathrm{S}$ e $38^{\circ} 45^{\prime}$ a $\left.39^{\circ} 15^{\prime} \mathrm{W}\right)$ situa-se no norte do estado do Ceará, a $90 \mathrm{~km}$ de Fortaleza e possui uma área de 32.690 $\mathrm{km}^{2}$, constituindo um dos mais expressivos compartimentos de relevos elevados do nordeste brasileiro. Desenvolve-se em litologias do complexo gnáissico-migmatítico, com orientação NNE-SSW e apresenta uma altitude variando de 500 a 1.115 m (Araújo et al. 2006). A cobertura florestal varia de acordo com a altitude e/ou localização à barlavento ou sotavento. Assim, na escarpa a barlavento é encontrada a floresta ombrófila densa atlântica, conhecida por mata úmida serrana e na escarpa a sotavento, a floresta estacional decídua, abaixo de $600 \mathrm{~m}$ e a floresta estacional semidecídua, acima de 600 m (Araújo et al. 2006).

\section{Flora}

Foram coletadas espécies arbóreas, arbustivas, herbáceas, trepadeiras herbáceas e lenhosas (lianas) da família Leguminosae em áreas sob diferentes cotas altitudinais e nas distintas fitofisionomias. As coletas foram realizadas entre fevereiro de 2007 e fevereiro de 2009. A lista foi complementada com dados de Araújo et al. (2006), cujas as coletas foram realizadas entre agosto/2002 e junho/2005, e das coleções dos herbários EAC, IAN, IPA, R, RB, MG, HUEFS, MCCUFRN, PEUFR e UFP, siglas de acordo com Holmgren \& Holmgren (1998).

A terminologia para o hábito das espécies, que seguiu o sistema de classificação de Whittaker (1975) com algumas adaptações, foi a seguinte: árvores (plantas lenhosas com altura superior a $3 \mathrm{~m}$ ), arbustos (plantas lenhosas com a ramificação principal até $50 \mathrm{~cm}$ acima do nível do solo e, em geral, com altura não superior a $3 \mathrm{~m}$ ), subarbustos (plantas com caule principal lenhoso e ramificações secundárias herbáceas, em geral, com altura inferior a $2 \mathrm{~m}$ ), ervas (plantas com caule totalmente herbáceo), trepadeiras (trepadeiras herbáceas) e lianas (trepadeiras lenhosas). A classificação em tribo e genérica está de acordo com Lewis et al. (2005), exceto para os gêneros Bauhinia L. e Caesalpinia L., que seguem Wunderlin et al. (1981) e Polhill \& Vidal (1981), respectivamente

O sistema de classificação da vegetação adotado é o de Veloso et al. (1991), sendo as seguintes vegetações mencionadas no texto: floresta ombrófila densa amazônica, floresta ombrófila densa atlântica, floresta estacional semidecídua e decídua, savana estépica (conhecida por caatinga), savana (cerrado) e savana florestada (cerradão). O conceito de floresta atlântica (sensu lato) adotado nesse trabalho é o de Oliveira-Filho \& Fontes (2000), que engloba florestas ombrófilas, semidecíduas e decíduas. 


\section{Resultados e Discussão}

Na Serra de Baturité foram encontrados 56 gêneros e 132 espécies da família Leguminosae. A subfamília Papilionoideae apresentou maior riqueza de gêneros e espécies (31 e 58, respectivamente), seguida das subfamílias Mimosoideae (17 gêneros e 41 espécies) e Caesalpinioideae (oito gêneros e 33 espécies). Os gêneros mais diversos em espécies na área foram: Mimosa L. (15), Senna Mill.(12), Desmodium Desv. (sete) e Chamaecrista Moench, Bauhinia L., Inga Mill. e Aeschynomene L. (seis cada).

Os táxons arbóreos e arbustivos predominaram na área representando $54,2 \%$ das espécies. A Serra de Baturité apresentou uma maior riqueza em espécies arbóreas e arbustivas da família Leguminosae quando comparado com outros estudos realizados em diferentes formações vegetacionais do nordeste brasileiro (Tab. 1). Esta elevada riqueza específica pode ser o resultado da grande heterogeneidade ambiental observada na área e conseqüentemente dos diferentes tipos vegetacionais ali encontrados. No entanto, cabe ressaltar que essa maior diversidade também pode ser resultado do grande esforço amostral, uma vez que no presente estudo o foco do trabalho foi a família Leguminosae, enquanto os trabalhos analisados são, em geral, levantamentos fitossociólogicos para todas as famílias de angiospermas em pequenas áreas delimitadas.

As espécies da família Leguminosae na área apresentam-se bem distribuídas nas diversas formações vegetacionais do Brasil. De maneira geral, as espécies que ocorrem na vertente sotavento são principalmente distribuídas em áreas de florestas estacionais e savana estépica, enquanto as espécies que ocorrem na vertente barlavento são encontradas principalmente em áreas de florestas ombrófilas (Atlântica e Amazônica).

Embora as duas vertentes estudadas estejam próximas geograficamente, percebe-se que estas possuem uma flora bem distinta, ressaltando a importância das mesmas para a conservação da diversidade em áreas remanescentes de floresta atlântica no semiárido brasileiro. Tal resultado pode ser consequência da marcada diferença climática entre as duas áreas, resultando em uma elevada riqueza de espécies e diversidade para a Serra de Baturité, tanto para flora de angiospermas (Araújo et al. 2006) como especificamente para a flora de Leguminosae (Lima et al. dados não publicados).

Tabela 1 - Riqueza de espécies arbóreas e arbustivas da família Leguminosae em diferentes formações vegetacionais do Nordeste brasileiro. $\mathrm{C}=$ Caesalpinioideae; $\mathrm{M}=$ Mimosoideae; $\mathrm{P}=$ Papilionoideae.

Table 1 - Richness of tree and shrub species of the family Leguminosae in different vegetation formations in Northeastern Brazil. C = Caesalpinioideae; $\mathrm{M}=$ Mimosoideae; $\mathrm{P}=$ Papilionoideae.

\begin{tabular}{lllll}
\hline Referências & Vegetação & C & M & P \\
\hline Este estudo & & 23 & 33 & 13 \\
Andrade \& Rodal (2004) & floresta estacional semidecídua & 06 & 03 & 05 \\
Araújo \& Martins (1999) & vegetação arbustiva caducifólia não espinhosa & 09 & 02 & 07 \\
Cardoso \& Queiroz(2007) & savana estépica & 24 & 18 & 09 \\
Cestaro \& Soares (2004) & floresta estacional decídua & 06 & 07 & 01 \\
Dionísio (2005) & floresta estacional semidecídua & 07 & 13 & 03 \\
Ferraz \& Rodal(2006) & floresta ombrófila densa & 06 & 10 & 04 \\
Lima et al. (2009) & floresta estacional semidecídua & 07 & 03 & 09 \\
Rodal \& Nascimento (2002) & floresta estacional semidecídua & 07 & 16 & 10 \\
Rodal \& Sales (2007) & floresta ombrófila densa & 06 & 15 & 08 \\
Rodal et al. (2005) & floresta ombrófila densa & 05 & 08 & 09 \\
Souza (2008) & savana estépica & 16 & 19 & 08 \\
\hline & & &
\end{tabular}




\section{Chave para identificação das subfamílias de Leguminosae da Serra de Baturité}

1. Folhas bipinadas, raramente pinadas (Inga); flores actinomorfas, geralmente com corola gamopétala, préfloração valvar (imbricada em Parkia), sementes com pleurograma em forma de ' $U$ ' .......... Mimosoideae

1'. Folhas bipinadas, pinadas, digitadas, bifolioladas, trifolioladas, unifolioladas ou simples; flores zigomorfas, raro quase actinomorfas, corola dialipétala, ou apenas as duas abaxiais fundidas apenas no ápice (Papilionoideae), pré-floração imbricada, sementes sem pleurograma em forma de ' $U$ '.

2. Folhas bipinadas, pinadas, bifolioladas (Hymenaea) ou unifolioada (Bauhinia); corola com préfloração imbricada ascendente, nunca papilionácea, cinco pétalas ou ausentes (Copaifera), sépalas geralmente livres entre si Caesalpiniodeae

2'. Folhas pinadas, trifolioladas, unifolioladas ou simples, nunca bipinadas; corola com pré-floração imbricada descendente, geralmente papilionácea, cinco petalas, sendo as duas abaxiais fundidas em forma de quilha, ou apenas uma pétala (Amburana, Ateleia e Trischidium), sépalas fundidas entre si. Papilionoideae

\section{Chave para identificação dos gêneros da subfamília Caesalpinioideae da Serra de Baturité}

1. Folhas unifolioladas ou bifolioladas.

2. Folhas unifolioladas Bauhinia

2'. Folhas bifolioladas Hymenaea

1'. Folhas pinadas ou bipinadas.

3. Folhas bipinadas.
4. Ramos com espinhos nodais; folha sem pecíolo, folíolos reduzidos; fruto moniliforme
4'. Ramos inermes; folha com pecíolo, folíolos desenvolvidos; fruto não moniliforme
Parkinsonia

3'. Folhas pinadas.

Caesalpinia

5. Folíolos com pontuações glandulares translúcidas; pétalas ausentes

5'. Folíolos sem pontuações glandulares translúcidas; pétalas presentes.

Copaifera

6. Filetes dos três estames abaxias sigmoidais, encurvados e muitas vezes maiores que a antera; nectários extraflorais ausentes.

6'. Filetes de todos os estames retos ou encurvados (nunca sigmoidais); nectários extraflorais geralmente presentes.

7. Pedicelo sem bractéola; frutos indeiscentes, ou deiscentes, mas com valvas não espiraladas após a abertura; nectários extraflorais quando presentes, claviformes .................. Senna

7'. Pedicelo com duas bractéolas; frutos deiscentes, com as valvas espiraladas após a abertura; nectários extraflorais, quando presentes, discóides, raramente planos, achatados Chamaecrista

Bauhinia L., Sp. Pl. 1:374-375

Bauhinia s.l. possui representantes com hábito variando de arbóreos e arbustivos à lianescentes. Caracteriza-se por possuir folhas unifolioladas, flores pentâmeras, sépalas concrescidas totalmente ou parcialmente, pétalas brancas ou róseas e frutos deiscentes. Gênero pantropical, porém, mais abundante no Neotrópico, pertencente à tribo Cercideae e com cerca de 300 espécies (Lewis et al. 2005). No Brasil são registradas cerca de 200 espécies (Vaz \& Tozzi 2005) e dessas, 14 são encontradas no Ceará, seis na Serra de Baturité.
Os estudos mais recentes de filogenia molecular de Bauhinia s.l. (Hao et al. 2003; Sinou et al. 2009) mostram que o gênero não é monofilético. Os autores sugerem a divisão deste gênero em outros oito, sendo proposto que as espécies neotropicais lianescentes sejam transferidas para o gênero Phanera. No entanto, o presente estudo não seguirá essa proposta porque, além da baixa amostragem de espécies nas análises filogenéticas, o trabalho de Sinou et al. (2009) mostra que Phanera, da forma como é tratado, é polifilético, sendo formado por dois clados, um com as espécies presentes na Ásia e outro com as espécies americanas. 


\section{Chave de identificação das espécies de Bauhinia da Serra de Baturité}

1. Plantas lianescentes, com gavinhas.

2. Lobos foliares concrescidos em cerca de $1 / 3$ ou menos do comprimento total, ápice acuminado; duas gavinhas presentes B. outimouta

2'. Lobos foliares concrescidos em cerca de $2 / 3$ ou mais do comprimento total, ápice arredondado; uma gavinha presente. B. glabra

1'. Plantas arbustivas ou arbóreas, nunca com gavinhas.

3. Ramos aculeados, nectários extraflorais ausentes.

4. Lobos foliares oblongos e fortemente divergentes, concrescidos em cerca de $1 / 3$ do comprimento total ..................................................................................... B. pentandra

4'. Lobos foliares ovado-oblongos, não divergentes, concrescidos em cerca de $2 / 3$ ou mais do comprimento total B. acreana

3'. Ramos inermes, nectários extraflorais presentes.

5. Folhas com ápice agudo ou longamente acuminado; pétalas linear-lanceoladas ... B. ungulata

5'. Folhas com ápice arredondado; pétalas obovado-oblongas a estreito-obovadas

B. aromatica

1. Bauhiniaacreana Harms, Notizbl. Königl. Bot. Gart. Berlin6: 307. 1915. Fig. 1a-b Bauhinia acreana é facilmente reconhecida pela combinação de hábito arbóreo, ramos aculeados, nectários extraflorais ausentes e flores brancas. A espécie é encontrada no Peru e no Brasil (RO, AC, AM, PA, CE e MT). Ocorre na floresta ombrófila densa amazônica, em formações de mata alta de terra firme, campo e em capoeiras (Vaz \& Tozzi 2005) e em áreas de floresta ombrófila densa atlântica no Ceará (Planalto da Ibiapaba e Chapada do Araripe). Na Serra de Baturité foi encontrada apenas em áreas de floresta ombrófila, acima de $800 \mathrm{~m}$.

Material selecionado: Guaramiranga, 25.I.2009, fl., J.R. Lima 731 (EAC, RB).

2. Bauhinia aromatica Ducke, Anais Acad. Brasil. Ci. 31(2): 295. 1959.

Espécie arbórea, caracterizada por apresentar pseudoracemos terminais, flores com sépalas lineares e pétalas brancas. Diferencia-se das demais espécies da Serra de Baturité por apresentar as estípulas semilunares e pétalas obovado-oblongas a estreito-obovadas. É encontrada apenas no Ceará. $\mathrm{Na}$ Serra de Baturité foi encontrada apenas em áreas de florestas estacionais.

Material selecionado: Baturité, 2.IV.2000, fr., M. Andrade (EAC 29198, RB 353382). Capistrano, 27.IV.1994, J.B.L.P. Medeiros (EAC21576). Mulungu, 16.IV.2008, fl.,J.R. Lima 439 (EAC, RB).

3. Bauhinia glabra Jacq., Enum. Syst. Pl.: 20. 1760.

Fig. 1c-d

Espécie lianescente, facilmente reconhecida por apresentar apenas uma gavinha e folhas com ápice arredondado, o que a diferencia de B. outimouta (duas gavinhas e folhas com ápice arredondado) e flores brancas. A espécie é encontrada no Brasil nos estados de RR, RO, AP, AM, PA, MA, CE e MS. Na Serra de Baturité é encontrada tanto em áreas da vertente barlavento como sotavento, principalmente em bordas das florestas estacionais e ombrófilas.

Material examinado: Baturité, 08.X.1980, E. Nunes 8929 (RB); Guaramiranga, 1.I.1996, fl., A.S.F. Castro (EAC 23535). Palmácia, 8.X.1980, fl., P. Martins (EAC 8929).

4. Bauhinia outimouta Aubl., Hist. Pl. Guiane 1: 375-377, pl. 144.1775. Fig. 1e

Espécie lianescente, com flores brancas e frutos deiscentes com valvas recobertas por indumento ferrugíneo, além de indumento ferrugíneo na face abaxial. Embora Queiroz (2006a) tenha feito uma nova combinação para a espécie, transferindo-a para o gênero Phanera, optamos por continuar utilizando o nome B. outimouta. Espécie neotropical, ocorrendo desde a América Central até o leste da América do Sul. Segundo Vaz (1993) é encontrada no Brasil nos seguintes estados: TO, CE, PB, PE, SE, BA, GO, MT, MS, DFe ES. Ocorre em florestas ombrófilas e em áreas de savana estépica, florestas de galerias e serranas, principalmente nos estados do Ceará e Paraíba, em altitudes de ca. $600 \mathrm{~m}$ (Queiroz 2006a). Espécie bem distribuída na Serra de Baturité, sendo encontrada em áreas de florestas estacionais e ombrófilas.

Material examinado: Aratuba, 31.XII.2000, fr.,A.S.F. Castro 917 (EAC). Baturité, Sítio Caridade, 7.IX.1938, fl. e fr., J. Eugênio 611 (RB). Guaramiranga, 24.II.1989, M.A. Figueiredo (EAC 15951). Mulungu, 22.IX.2001, A.S.F. Castro 1075 (EAC). Pacoti, 28.XII.1999, M. Andrade 20 (EAC). 

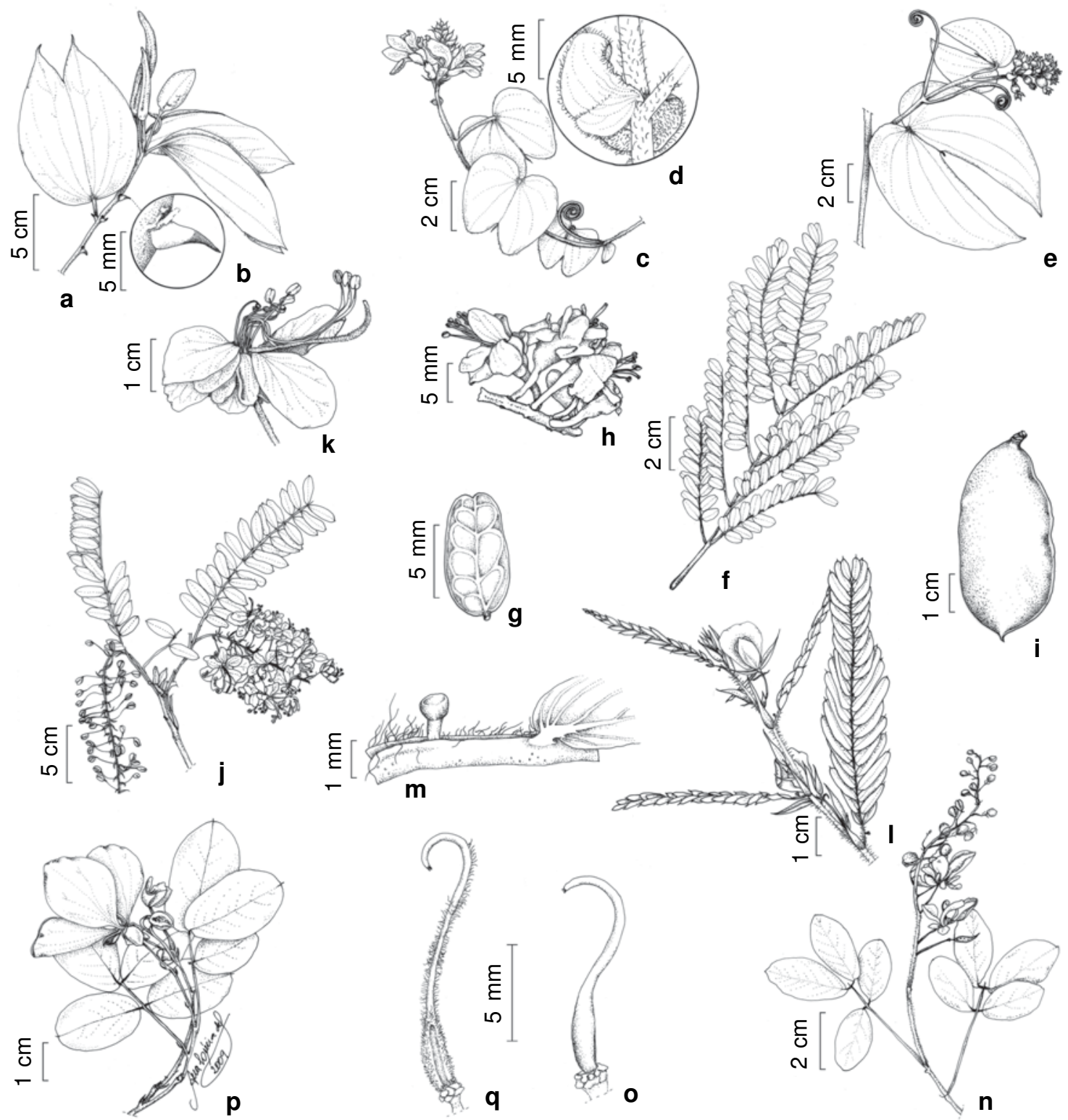

Figura 1 - a-b. Bauhinia acreana Harms - a. ramo com botão; b. detalhe do acúleo (M.A. Figueiredo - RB 392593). c-d. Bauhinia glabra Jacq. - c. ramo com inflorescência; d. detalhe da estípula (E. Nunes \& P. Martins - RB 392569). e. Bauhinia outimouta Aubl. - ramo com inflorescência (J.R. Lima 221). f-i. Caesalpinia ferrea var.parvifolia Benth. -f. folha; g. folíolo (J.R. Lima 177); h. inflorescência (J.R. Lima 722); i. fruto (J.R. Lima 177). j-k. Cassia ferruginea H.S. Irwin \& R.C. Barneby var. ferruginea - j. ramo com inflorescência; k. flor (J.R. Lima 723). 1-m. Chamaecrista duckeana (Bezerra \& Fernandes) H.S. Irwin \& Barneby - 1. ramo com flor; m. detalhe do nectário extrafloral (J.R. Lima 564). n-o. Chamaecrista zygophylloides var. colligans (H.S. Irwin \& Barneby) H.S. Irwin \& Barneby - n. ramo com inflorescência; o. gineceu (J.R. Lima 509). p-q. Chamaecrista zygophylloides (Taub.) H.S. Irwin \& Barneby var. zygophylloides - p. ramo com inflorescência; q. gineceu (J.R. Lima 432).

Figure 1 - a-b. Bauhinia acreana Harms - a. branch with bud; b. details of the aculeus. c-d. Bauhinia glabra Jacq. - c. branch with inflorescence; d. detail of the stipule. e. Bauhinia outimouta Aubl. - branch with inflorescence. f-i. Caesalpinia ferrea var. parvifolia Benth. - f. leaf; g. leaflets; h. inflorescence; i. fruit. j-k. Cassia ferruginea H.S. Irwin \& R. C. Barneby var. ferruginea - j. branch with inflorescence; k. flower. 1-m. Chamaecrista duckeana (Bezerra \& Fernandes) H.S. Irwin \& Barneby - 1. branch with flower; m. detail of the extrafloral nectary. n-o. Chamaecrista zygophylloides var. colligans (H.S. Irwin \& Barneby) H.S. Irwin \& Barneby $-\mathrm{n}$. branch with inflorescence; o. gynoecium. Chamaecrista zygophylloides (Taub.) H.S. Irwin \& Barneby var. zygophylloides - p. branch with inflorescence; q. gynoecium. 
5. Bauhinia pentandra (Bong.) Vogel ex Steud., Nomencl. Bot. (ed. 2) 1:992. 1840.

Espécie arbustiva, facilmente reconhecida por apresentar folhas concrescidas em até $1 / 3$ do comprimento, com lobos foliares oblongos e fortemente divergentes, ramos aculeados e nectários extraflorais ausentes, além das flores com estames dimórficos (cinco estames férteis e cinco estaminódios). No Nordeste do Brasil, a espécie é observada em áreas de transição entre a savana estépica e a savana e em florestas estacionais e no Centro-Oeste sua presença foi relatada em áreas de savana florestada, mata de galeria e floresta estacional (Vaz \& Tozzi 2005). Na Serra de Baturité foi encontrada em áreas de florestas estacionais e ombrófilas.

Material selecionado: Aratuba, 9.VI.2000, fl., A. Fernandes (EAC 29863). Capistrano, 27.VI.1994, fr., J.B.L.P. Medeiros (EAC 21578). Redenção, 15.III.1998, A.S.F. Castro 540 (EAC).

6. Bauhinia ungulata L., Sp. PL. 1:374. 1753. 6.1 Bauhinia ungulata $\mathrm{L}$. var. ungulata

Bauhinia ungulata possui hábito variando de arbóreo a arbustivo, folhas com ápice agudo ou longamente acuminado, pétalas linear-lanceoladas e as flores possuem sépalas fendidas, onduladas a retorcidas e pétalas linear-lanceoladas. Espécie neotropical. No Nordeste do Brasil habita áreas de vegetação arbustiva caducifólia não espinhosa (carrasco), savana estépica, floresta estacional, savana, savana florestada e vegetação secundária (Vaz\& Tozzi 2005). Na Serra de Baturité foi encontrada em áreas de florestas estacionais e ombrófilas.

Material selecionado: Baturité, 25.VI.1999, M. Andrade (EAC 28187). Capistrano, 8.VIII.1994, J.B.L.P. Medeiros et al. (EAC 21571). Pacoti, 30.VII.1941, P. Bezerra 298(EAC).

Caesalpinia L., Sp. Pl. 1: 380-381. 1753.

Gênero com espécies arbóreas e arbustivas, caracterizado pelas folhas bipinadas sem nectários extraflorais, flores pentâmeras, amarelas e fruto do tipo legume deiscente ou indeiscente. Caesalpinia é um gênero pantropical pertencente à tribo Caesalpinieae, com cerca de 130 espécies (Lewis 1998), das quais aproximadamente 40 ocorrem na América do Sul (Ulibarri 1996). Segundo Lewis (1998) existem quatro centros de diversidade do gênero, entre eles o semiárido nordestino, principalmente as áreas de savana estépica. Na Serra de Baturité foram registrados cinco táxons infraespecificos.

De acordo com Lewiset al. (2005), Caesalpinia não é monofilético e os autores sugerem a divisão deste em gêneros menores, que no caso da Serra de Baturité, corresponderiam à Libidibia (DC.) Schltdl. e Poincianella Britton \& Rose. No entanto, neste trabalho decidimos considerar todas as espécies como pertencentes ao gênero Caesalpinia s.l. até que uma proposta de classificação formal baseada tantos em estudos filogenéticos como morfológicos seja publicada.

\section{Chave de identificação das espécies de Caesalpinia da Serra de Baturité}

1. Foliólulos alternos com base assimétrica; frutos deiscentes C. gardneriana

1'. Foliólulos opostos com base simétrica; frutos indeiscentes C. ferrea

7. Caesalpinia gardneriana Tul., Arch. Mus. Hist. Nat. 4: 141.1844.

Espécie arbórea ou arbustiva, com folhas bipinadas, foliólulos alternos e frutos do tipo legume deiscente. A espécie é semelhante à $C$. bracteosa e $C$. pyramidalis, das quais, segundo vários autores (ver Bentham 1870; Ulibarri 1996; Lewis 1987; Lewis 1998), se diferenciam principalmente pela posição da articulação entre o pedicelo e a flor e forma das brácteas, no entanto, pode se observar várias sobreposições destes caracteres, o que demonstra a necessidade de uma revisão do grupo. No Nordeste do Brasil ocorre em áreas de savana estépica e floresta estacional, do Piauí até Pernambuco(Lewis 1998). Na Serra de Baturité foi encontrada somente em áreas de floresta estacional.
Material selecionado: Baturité, 26.IX.1908, fl. e fr., $A$. Ducke (MG 1178). Capistrano, 27.IV.1994, fl., J.B.L.P. Medeiros s.n. (RB 21575). Mulungu, 17.IV.2008, fl., J.R. Lima 466 (RB).

8. Caesalpinia ferrea Mart., Arch. Mus. Hist. Nat. Paris 4: 137. 1844.

Espécie arbórea, com folhas bipinadas, foliólulos opostos e frutos do tipo legume indeiscentes. Ocorre no Brasil em áreas de florestas estacionais (Prado \& Gibbs 1993) e em formações de savana estépica e savana (Ulibarri 1996). Na Serra de Baturité ocorrem três variedades de $C$. ferrea. Essas três variedades apresentam muitos caracteres intermediários, o que torna a distinção entre elas complexa. 


\section{Chave para as variedades deC. ferrea na Serra de Baturité}

1. Pinas 5, foliólulos 8 a 12 .

2. Foliólulos pubescentes

C. ferrea var.ferrea

2'. Foliólulos glabros

C. ferrea var. glabrescens

1'. Pinas 11, foliólulos 16 a 30 C. ferrea var. parvifolia

\subsection{Caesalpinia ferrea Mart. var.ferrea}

Caesalpinia ferrea var.ferrea é semelhante a C. ferrea var. glabrescens por apresentar foliólulos em número e tamanho aproximadamente iguais, no entanto diferencia-se por serem pubescentes (sendo glabro em C. ferrea var. glabrescens). No Nordeste do Brasil ocorre principalmente em áreas de floresta estacional, sendo encontrada também em áreas de savana estépica (Queiroz 2006b). Na Serra de Baturité foi encontrada em áreas de florestas estacionais e ombrófilas.

Material examinado: Pacoti, 14.XI.2007, J.R. Lima 399 (EAC, RB).

\subsection{Caesalpinia ferrea Mart. glabrescens Benth.,} Martius, Fl. bras. 15(2): 70. 1870.

É semelhante à $C$. ferrea var. ferrea pelo tamanho e número de foliólulos, no entanto diferencia-se pelo fato dos mesmos serem glabros. Ocorre em todo Nordeste brasileiro, principalmente em áreas de savana estépica (Queiroz 2009; Queiroz 2006b). Na Serra de Baturité foi encontrada em áreas de floresta estacional decídua.

Material examinado: Baturité, 1.IX.1937, fr., J.E. Leite $612(\mathrm{RB})$.
8.3 Caesalpinia ferrea Mart. var. parvifolia Benth., Martius, Fl. bras. 15(2): 70. $1870 . \quad$ Fig. 1f-i Diferencia-se das outras variedades por apresentar maior número de pinas e de foliólulos por pina e por serem relativamente menores. É frequente em áreas de florestas estacionais e savana estépica no Nordeste do Brasil e estende-se até o Sudeste (ES e RJ). Na Serra de Baturité foi encontrada em áreas de floresta estacional semidecídua e também em áreas de floresta ombrófila.

Material selecionado: Guaramiranga, 15.VII.2008, fr.,M.O.T. Menezes 61 (EAC). Mulungu, 19.IX.2007, fr., J.R. Lima 177 (RB). Pacoti, 13.XI.2007, J.R. Lima 370 (EAC, RB).

Cassia L., Sp. Pl. 1: 376-380.

Gênero arbóreo, facilmente reconhecido pelos estames abaxiais do tipo sigmoidal, pela presença de duas bractéolas no pedicelo e ausência de nectários extraflorais. Gênero pantropical, pertencente à tribo Cassieae Bronn, subtribo Cassinae Irwin \& Barneby, com cerca de 30 espécies, sendo 12-13 nativas das Américas (Lewis et al. 2005; Irwin \& Barneby 1982). Os principais centros de diversidade são a floresta ombrófila densa amazônica e a floresta ombrófila densa atlântica, sendo encontrada também em áreas de florestas estacionais, savana estépica e savana. $\mathrm{Na}$ Serra de Baturité foram encontradas duas espécies.

\section{Chave de identificação das espécies de Cassia da Serra de Baturité}

1. Brácteas ou bractéolas persistentes; flores amarelas

1'. Brácteas ou bractéolas caducas; flores róseas C. ferruginea C. grandis

9. Cassia ferruginea (Schrader) Schrader ex DC., Prodr. 2: 489. 1825.

9.1 Cassia ferruginea (Schrader) Schrader ex DC. var.ferruginea. Fig. 1j-k

Cassia ferruginea var. ferruginea é caracterizada pelas estípulas peltadas, folhas paripinadas e espiraladas. É facilmente reconhecida pelas inflorescências pendentes com flores amarelas. Ocorre do Ceará à Minas Gerais, chegando até Goiás. É encontrada em formações como savana florestada, florestas estacionais e áreas limites entre essa a savana estépica. Na Serra de Baturité foi encontrada em áreas de floresta ombrófila.

Material examinado: Baturité, 1861, fl., F.F. Allemão \& M. Cysneiros 452 (R). Guaramiranga, 24.II.1989, fl., A. Fernandes (EAC 15941).

10. Cassia grandis L.f., Suppl. Pl.: 230. 1781. Cassia grandis diferencia-se de C. ferruginea var.ferruginea por apresentar flores róseas. Ocorre 
na América Central a América do Sul, sendo encontrada em florestas de terras baixas, ripárias e semidecíduas (Irwin \& Barneby 1982). Na Serra de Baturité foi encontrada tanto em áreas a barlavento como sotavento.

Material examinado: Aratuba, 10.X.1982, fl., M.A. Figueiredo (EAC 11711). Guaramiranga, 14.XI.1990, A. Fernandes (EAC 17043).

Chamaecrista Moench., Methodus: 272. 1794.

As espécies desse gênero podem variar de ervas (eretas ou prostradas), subarbustos a arbustos. Possuem folhas paripinadas (um a muitos pares de folíolos) com bractéolas presentes, flores pentâmeras, sépalas livres, pétalas amarelas e frutos deiscentes do tipo legume. É um gênero pantropical com cerca de 265 espécies, das quais 239 são nativas do continente americano (Irwin \& Barneby 1982). O Brasil possui cerca de 230 espécies (Irwin \& Barneby 1982) e, segundo Lewis (1987), a Bahia é o centro de radiação do gênero. Na Serra de Baturité foram encontrados cinco táxons específicos e dois intraespecíficos principalmente em áreas de florestas estacionais.

\section{Chave de identificação das espécies de Chamaecrista da Serra de Baturité}

1. Inflorescência axilar.

2. Folhas com quatro ou mais folíolos.

3. Subarbusto; folhas com mais de 4 folíolos; nectários foliares presentes C. duckeana

3'. Erva prostrada; folhas com exatamente 4 folíolos; nectários foliares ausentes C. absus

2'. Folhas com exatamente 2 folíolos C. rotundifolia

1'. Inflorescência terminal.

4. Pecíolo de comprimento semelhante ao dos folíolos proximais. C. belemii

4'. Pecíolo cerca de 1,5 vezes mais longo do que os folíolos proximais C. zygophylloides

11. Chamaecrista absus (L.) H.S.Irwin \& Barneby, Mem. New York Bot. Gard. 35: 664. 1982.

Dentre as espécies de Chamaecrista da Serra de Baturité, C. absus é facilmente reconhecida pela combinação do hábito herbáceo (prostrado), dois pares de folíolos e fruto com tricomas glandulares. Espécie pantropical, amplamente distribuída nas Américas (Irwin \& Barneby 1982). Na Serra de Baturité foi encontrada em áreas de floresta estacional.

Material examinado: Mulungu, 17.VII.2008, fr., J.R. Lima 680 (RB).

12. Chamaecrista belemii (H.S. Irwin \& Barneby) H.S. Irwin \& Barneby, Mem. New York Bot. Gard. 35: 660. 1982.

Espécie arbustiva com dois pares de folíolos e sem nectários extraflorais. A espécie é semelhante a $C$. zygophylloides, no entanto se diferencia desta por apresentar pecíolo e folíolos menores. C. belemiié encontrada principalmente em áreas de savana estépica, sendo neste estudo encontrada em área de floresta estacional semidecídua.

Material examinado: Mulungu, 5.VI.2008, fr., J.R. Lima 524 (EAC, RB).
13. Chamaecrista duckeana (Bezerra \& Fernandes) H.S. Irwin \& Barneby, Mem. New York Bot. Gard. 35: 861. 1982.

Fig. 11-m

Espécie subarbustiva, caracterizada pelas folhas com nectário extrafloral estipitado localizado no pecíolo. Encontrada apenas em áreas úmidas do Ceará (Irwin \& Barneby 1982). Na Serra de Baturité foi encontrada em áreas de florestas estacionais e ombrófilas.

Material selecionado: Aratuba, 9.VI.2000, A. Fernandes (EAC 29864). Baturité, 29.IV.1909, fl. e fr.,A. Ducke (MG 2065, RB 11347).Capistrano, 30.V.1994, fl.,J.B.L.P. Medeiros et al. 59 (EAC). Guaramiranga, 12.IX.2003, fl., V. Gomes et al. 754 (EAC). Pacoti, 26.VI.2008, fl., J.R. Lima 564 (RB).

14. Chamaecrista rotundifolia (Pers.) Greene, Pittonia 4 (20D): 31.1899.

14. 1 Chamaecrista rotundifolia (Pers.) Greene var. rotundifolia

Espécie facilmente reconhecida na Serra de Baturité por apresentar o hábito herbáceo (prostrado), um par de folíolos e flores com pétalas obovadas. Espécie neotropical encontrada em áreas de savana, florestas estacionais e florestas alteradas (Irwin \& Barneby 1982). Na Serra de Baturité foi encontrada em áreas de floresta estacional.

Material selecionado: Baturité, 17.V.1959, fl.,A. Fernandes s.n. (EAC 1871). 
15. Chamaecrista zygophylloides (Taub.) H.S. Irwin \& Barneby, Mem. New York Bot. Gard. 35: 660. 1982.

Espécie arbustiva, folhas com dois pares de folíolos, sem nectários extraflorais e inflorescência terminal com flores amarelas. É semelhante à $C$. belemii, no entanto diferencia-se desta por apresentar o pecíolo maior (1,5 vezes mais longo do que os folíolos proximais, enquanto em C. belemii o pecíolo tem tamanho semelhante ao dos folíolos proximais). Distribui-se desde o México e América Central, Guianas e Venezuela e no leste do Brasil, do Ceará a Minas Gerais (Irwin \& Barneby 1982). Encontrada em áreas de savana estépica, associada às serras do Ceará até a Bahia (Irwin \& Barneby 1982). Na Serra de Baturité foram encontradas duas variedades localizadas em áreas de floresta estacional.

\section{Chave de identificação das variedades de $C$. zygophylloides da Serra de Baturité}

1. Ovário e fruto gabros C. zygophylloides var. coligans

1'. Ovário e fruto pilosos C. zygophylloides var. zygophylloides

15.1 Chamaecrista zygophylloides var. colligans (H.S. Irwin \& Barneby) H.S. Irwin \& Barneby, Mem. New York Bot. Gard. 35: 661. $1982 . \quad$ Fig. 1n-o

Diferencia-se de C. zygophylloides var. zygophylloides por apresentar ovário e frutos glabros. Ocorre em áreas de savana estépica, estando principalmente associada às serras do Ceará até a Bahia (Irwin \& Barneby 1982), entre 600 e $900 \mathrm{~m}$ de altitude.

Material examinado: Guaramiranga, 18.IV.2008, fl. e fr., J.R. Lima 509 (EAC, RB).

15.2 Chamaecrista zygophyloides (Taub.) H.S.Irwin \& Barneby var. zygophyloides, Mem. New York Bot. Gard. 35: 660. $1982 . \quad$ Fig. 1p-q

Diferencia-se de C. zygophylloides var. colligans por apresentar ovário e frutos pilosos. Ocorre em áreas de savana estépica, savana e floresta estacional (Irwin \& Barneby 1982). Na Serra de Baturité é encontra principalmente em áreas de floresta estacional.

Material selecionado: Mulungu, 16.IV.2008, fl., J.R. Lima 432 (EAC, RB).

Copaifera L., Sp. Pl. (ed. 2) 1: 557. 1792.

Gênero arbóreo caracterizado pela combinação de folhas com pontuações glandulares translúcidas e pétalas ausentes. Apresenta distribuição pantropical e pertence à tribo Detarieae. O gênero possui 38 espécies, das quais 33 ocorrem nas Américas, quatro na África e uma na Malásia (Costa 2007). O gênero é mais diverso na América do Sul, onde são encontradas 25 espécies (Lewis et al. 2005). Na Serra de Baturité foi encontrada apenas uma espécie.
16. Copaifera duckei Dwyer, Brittonia 7(3): 163164. 1951.

Fig. 2a-c

A espécie é facilmente reconhecida pelos folíolos com pontuações glandulares e flores apétalas e estames brancos. Encontrada em áreas de florestas ombrófilas no Nordeste do Brasil, Rio de Janeiro e Tocantins (Costa 2007). Embora ocorra na região semiárida do Brasil, é apenas encontrada em florestas ombrófilas localizadas sobre serras dentro deste domínio (Chapada do Araripe e Ibiapaba) e da Bahia até o Rio de Janeiro (Costa 2007).

Material selecionado: Baturité, IX.1955, fr., $F$. Linhares 8108 (IPA). Guaramiranga, 12.XI.2007, J.R. Lima 417 (EAC, RB). Pacoti, 12.XI.2007, fl., J.R. Lima 383 (EAC, RB).

Hymenaea L., Sp. Pl. 2: 1192. 1753.

Gênero caracterizado pelo hábito arbóreo, folhas bifolioladas, sem nectários extraflorais, inflorescências em panículas, com flores pentâmeras, quatro sépalas e cinco pétalas e frutos indeiscentes. Hymenaea pertence à tribo Detarieae com espécies predominantemente neotropicais, ocorrendo do México ao norte da Argentina, e uma espécie na costa oriental da África (Lee \& Langenheim 1975). Na Serra de Baturité foi encontrada apenas uma espécie.

17. Hymenaea courbaril var. courbaril L., Sp. Pl. 2:1192. $1753 . \quad$ Fig. 2d-e

A espécie é facilmente reconhecida pela combinação de folhas bifolioladas e flores com sépalas obovais, tricomas ferrugíneos na face externa e amarelos na face interna e pétalas brancas. Ocorre na América Tropical e Antilhas, desde florestas ombrófilas até áreas de savana estépica, 


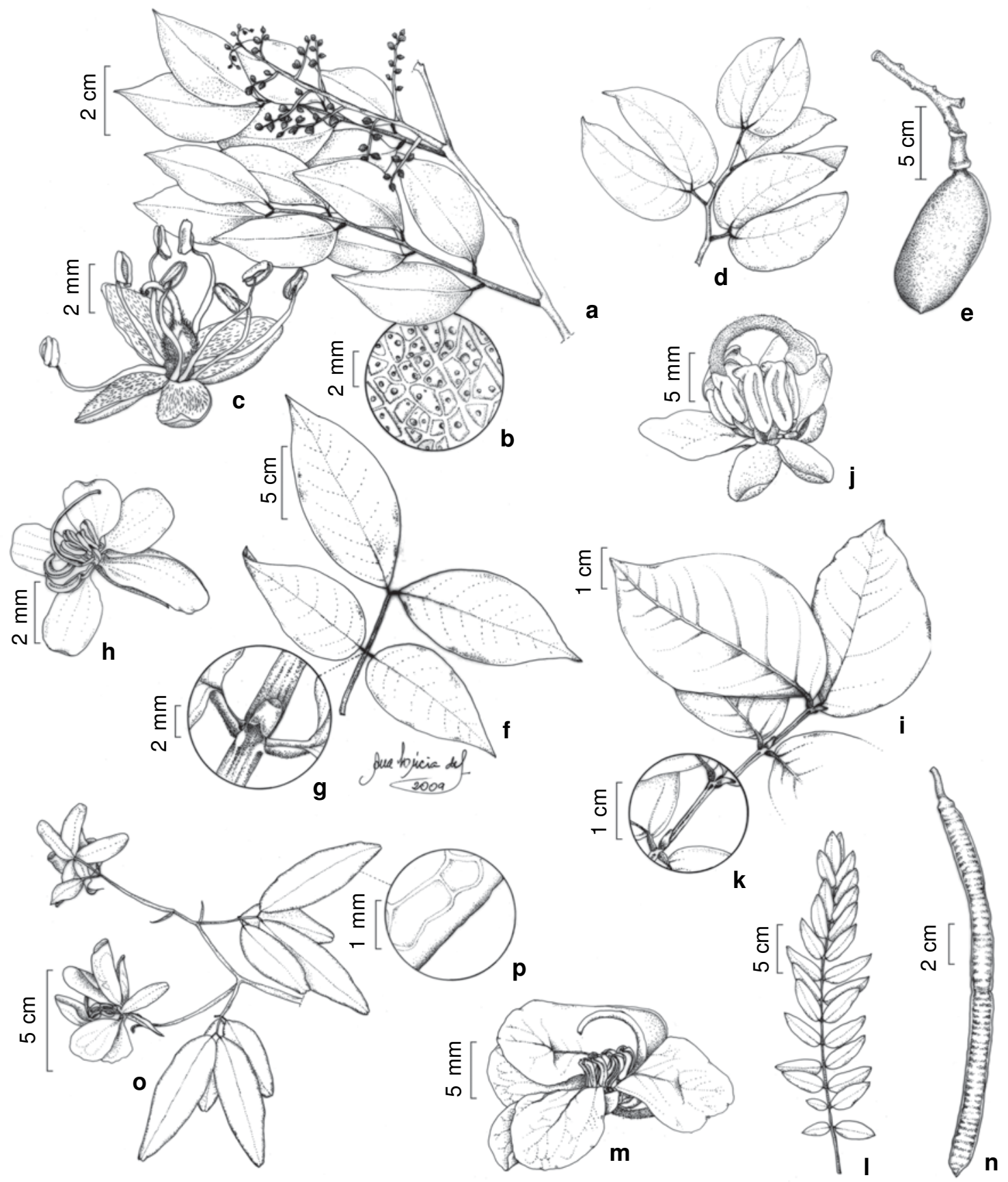

Figura 2 - a-c. Copaifera duckei Dwyer - a. ramo com inflorescência; b. detalhe da folha; c. flor (J.R. Lima 383). d-e. Hymenaea courbaril L-d. folha; e. fruto (J.R. Lima 646). f-h. Senna georgica H.S. Irwin \& R. C. Barneby var. georgica - f. folha; g. detalhe do nectário extrafloral; h. flor (J.R. Lima 252). i-k. Senna quinquagulata (Rich.) H.S. Irwin \& Barneby var. quinquangulata - i. folha; j. flor; k. detalhe do nectário extrafloral (J.R. Lima 167). 1-n. Senna spectabilis var. excelsa (Schrad.) H.S. Irwin \& Barneby - 1. folha; m. flor; n. fruto (J.R. Lima 511). o-p. Senna splendida var. gloriosa H.S. Irwin \& Barneby - o. ramo com flores; p. detalhe da folha (J.R. Lima 210).

Figure 2 - a-c. Copaifera duckei Dwyer - a. branch with inflorescence; b. detail of the leaf; c. flower. d-e. Hymenaea courbaril L - d. leaf; e. fruit f-h. Senna georgica H.S. Irwin \& R.C. Barneby var. georgica - f. leaf; g. detail of the extrafloral nectary; h. flower. i-k. Senna quinquagulata (Rich.) H.S. Irwin \& Barneby var. quinquangulata - i. leaf; j. flower; k. detail of the extrafloral nectary. 1-n. Senna spectabilis var. excelsa (Schrad.) H.S. Irwin \& Barneby - 1. leaf; m. flower; n. fruit. o-p. Senna splendida var. gloriosa H.S. Irwin \& Barneby - o. branch with flowers; p. detail of the leaf. 
sendo muito comum nas áreas mais secas da floresta ombrófila densa amazônica (Lee \& Langenheim 1975). Na Serra de Baturité foi encontrada em áreas de floresta ombrófila.

Material selecionado: Pacoti, 10.VII.2008, fr., J.R. Lima 646 (RB).

\section{Parkinsonia L., Sp. Pl. 1: 375}

Gênero com espécies arbustivas ou arvoretas caracterizado pelos ramos com espinhos nos nós e frutos moniliformes. Possui cerca de 12 espécies com distribuição afro-americana (Lewis et al. 2005). Na Serra de Baturité foi encontrada apenas uma espécie.

18. Parkinsonia aculeata L., Sp. Pl. 1: 375. 1753. Iconografia: Queiroz (2009)

Parkinsonia aculeata é reconhecida pelos ramos com espinhos nodais, inflorescência racemiforme, axilar, flores com sépalas verde-amareladas e pétalas amarelas, androceu com dez estames, ovário piloso e fruto moniliforme. P. aculeata é uma espécie encontrada na América e na África tropicais, geralmente em áreas secas (Queiroz 2009). Na Serra de Baturité foi encontrada apenas em áreas de florestas estacionais.

Material examinado: Baturité, IX.1897, fl. e fr., $H$. Huber (MG 69).

Senna Mill., Gard. Dict. Abr. (ed. 4) no. 3. 1754.

Gênero representado por espécies arbustivas, subarbustivas e herbáceas. É caracterizado pelas folhas paripinadas, folíolos opostos (dois a muitos pares), nectários extraflorais presentes ou ausentes, flores pentâmeras, sépalas livres e pétalas amarelas. Gênero pantropical com cerca de 300 espécies, mais diverso nas Américas, porém, bem representado na África e Austrália, pobremente na Ásia e Oceania. Na Serra de Baturité foram encontradas 12 espécies.

\section{Chave de identificação das espécies deSenna da Serra de Baturité}

1. Folhas sem nectários

S. spectabilis

1'. Folhas com nectários.

2. Nectário inserido na base do pecíolo, próximo do ou no pulvino.

3. Caule e folhas hirsutas S. hirsuta

3'. Caule e folhas glabros ou glabrescentes S. occidentalis

2'. Nectário inserido próximo ou acima da metade do pecíolo, frequentemente entre o primeiro par de folíolos.

4. Anteras dos 7 estames férteis de tamanho semelhante S. uniflora

4'. Anteras dos 7 estames férteis diferenciados em dois conjuntos: 4 medianos mais curtos e 3 abaxiais mais longos.

5. Folhas com mais de dois pares folíolos.

6. Ervas ou subarbustos; folhas com três pares de folíolos, nectário séssil; flores ca. $1,5 \mathrm{~cm}$ de diâmetro S. obtusifolia

6'. Arbustos ou arvoretas; folhas com mais de três pares de folíolos, nectário estipitado; flores ca. 3-4 cm de diâmetro.

7. Nectário entre os folíolos do primeiro par basal; fruto cilíndrico... S. pendula

7'. Nectários entre os folíolos de todos os pares; fruto plano-compresso

S. trachypus

5'. Folhas com dois pares de folíolos.

8. Um nectário por folha presente entre os folíolos do par basal.

9. Folíolos glabros, base aproximadamente simétrica.

10. Folíolos ovais, nectário estipitado S. georgica

10’. Folíolos elípticos, nectário séssil S. splendida

9'. Folíolos pubescentes, base assimétrica S. macranthera

8'. Dois nectários por folha, presentes entre os folíolos dos pares basais e distais.

11. Estames férteis distintos em comprimento S. pilifera

11'. Estames férteis semelhantes em comprimento S. quinquagulata 
19. Senna georgica Irwin \& Barneby, Mem. New York Bot. Gard. 35: 193. 1982.

19.1 Senna georgica Irwin \& Barneby var. georgica.

Fig. 2f-h

É semelhante a $S$. quinquagulata, porém, diferencia-se vegetativamente desta pela presença de um único nectário extrafloral entre os folíolos do primeiro par, além possuir os estames férteis de tamanho distintos em comprimento e forma. $S$. quinquagulata possui dois nectários entre os folíolos dos pares basais e distais e estames férteis de tamanho semelhante. Segundo Irwin \& Barneby (1982) ocorre nas Guianas, Bolívia, Paraguai e Brasil (PA, MT, CE e PE). Na Serra de Baturité foi encontrada tanto em áreas de florestas ombrófilas e estacionais, principalmente em trilhas e bordas de fragmentos.

Material selecionado: Aratuba, 30.VIII.1980, M.A. Figueiredo (EAC 8921). Baturité, Sítio Caridade, 21.IX.1939, fl. e fr., J.E. Leite 619 (RB). Capistrano, 16.X.1979, E. Nunes et al. s.n. (EAC 7101). Guaramiranga, 12.IX.1993, M.R.L.Oliveira (EAC 23017). Mulungu, 9.X.2007, fl., J.R. Lima 252 (EAC, RB). Pacoti, 9.X.1990, E. Nunes et al. (EAC 16948).

20. Senna hirsuta (L.) H.S. Irwin \& Barneby, Phytologia 44 (7): 499. 1979.

20.1 Senna hirsuta (L.) H.S. Irwin \& Barneby var. hirsuta

Das seis variedades da espécie (Irwin \& Barneby 1982), apenas a variedade hirsuta foi encontrada na Serra de Baturité, sendo reconhecida pela combinação de nectário extrafloral na base do pecíolo e ramos glabros ou glabrescentes. Segundo Irwin \& Barneby (1982), apresenta-se amplamente distribuída nas Américas, desde os Estados Unidos até a Argentina. O táxon foi encontrado apenas em áreas de floresta ombrófila da Serra de Baturité.

Material examinado: Baturité, 21.IV.1986, A. Fernandes et al. (EAC 14206).

21. Senna macranthera (Collad.) H.S. Irwin \& Barneby, Mem. New York Bot. Gard. 35: 181. 1982. 21.1 Senna macranthera var. striata (Vogel) H.S. Irwin \& Barneby, Mem. New York Bot. Gard. 35: 185. 1982.

Árvores ou arvoretas, folhas com dois pares de folíolos com um nectário extrafloral entre o primeiro par, flores com pétalas amarelas e fruto cilíndrico. Ocorre na Venezuela, Equador, Peru e no Brasil desde o Piauí até São Paulo (Irwin \& Barneby 1982), sendo cultivada de São Paulo até Rio Grande do Sul. É encontrada desde borda de florestas ombrófilas até áreas abertas. $\mathrm{Na}$ Serra de Baturité foi encontrada em áreas de floresta estacional.

Material examinado: Aratuba, 15.V.1980, E. Nunes et al. (EAC 8602).

22. Senna obtusifolia (L.) H.S. Irwin \& Barneby, Mem. New York Bot. Gard. 35: 252. 1982.

Espécie herbácea ou subarbustiva. $S$. obtusifolia apresenta certa semelhança com $S$. uniflora, podendo ser facilmente diferenciada desta pela ausência de tricomas ferrugíneos nos ramos e frutos com valvas planas. Segundo Irwin \& Barneby (1982) é provavelmente originária da América, com ampla distribuição desde o México até a Argentina, sendo encontrada em regiões tropicais da Ásia e África. Na Serra de Baturité foi encontrada em áreas de floresta estacional.

Material examinado: Baturité, 26.VI.1908, fl. e fr., $A$. Ducke (MG 1161). Capistrano, Fazenda Araçanga, 14.VII.1994, J.B.L.P. Medeiros 121 (EAC).

23. Senna occidentalis (L.) Link, Handbuch 2: 140. 1831.

Espécie arbustiva ou subarbustiva reconhecida pela combinação de folhas com quatro a seis pares de folíolos e nectário extrafloral na base ou próximo do ou no pulvino. É encontrada em toda a América tropical e subtropical, bem como na África, Ásia e Austrália (Irwin \& Barneby 1982). No Nordeste brasileiro ocorre principalmente em áreas degradadas. Na Serra de Baturité é encontrada em áreas de floresta ombrófila e estacional.

Material selecionado: Pacoti, 25.IX.1981, F.S. Cavalcanti et al. (EAC 10856).

24. Senna pendula (Willd.) H.S. Irwin \& Barneby, Mem. New York Bot. Gard. 35: 378. 1982.

Espécie arbustiva, caracterizada pela folhas com seis pares de folíolos e nectário extrafloral no primeiro par (basal) e frutos cilíndricos e pêndulos. Distribui-se desde o México até a Argentina, possuindo ampla distribuição no Brasil (Irwin \& Barneby 1982). Na Serra de Baturité foi encontrada em áreas de floresta ombrófila.

Material selecionado: Aratuba, 15.V.1980, E. Nunes (EAC 8642). Guaramiranga, 12.VI.1976, A. Fernandes (EAC 2789).

25. Senna pilifera (Vogel) H.S. Irwin \& Barneby, Mem. New York Bot. Gard. 35: 241. 1982.

Espécie subarbustiva (prostrada ou decumbente) caracterizada pelas folhas sempre 
com dois pares de folíolos e nectários extraflorais presentes entre cada par de folíolos, androceu com dez estames férteis distintos em comprimento e forma e frutos comprimidos. Distribui-se do México até o Brasil e Uruguai (Irwin \& Barneby 1982). Na Serra de Baturité foi encontrada em áreas de florestas ombrófilas.

Material selecionado: Guaramiranga, 13.VIII.1976, A. Fernandes (EAC 2849). Serra de Baturité, 20.VII.1991, E. Nunes (EAC 17853).

26. Senna quinquangulata (Rich.) H.S. Irwin \& Barneby, Mem. New York Bot. Gard. 35: 153. 1982. 26.1 Senna quinquangulata (Rich.) H.S. Irwin \& Barneby var. quinquangulata.

Fig. 2i-k

Arbusto caracterizado pelas folhas com apenas dois pares de folíolos e nectário extrafloral entre cada par de folíolos e androceu com sete estames férteis de tamanho semelhante. É encontrada na floresta ombrófila densa amazônica e em áreas de floresta ombrófila densa atlântica. Na Serra de Baturité foi encontrada em áreas a barlavento, principalmente nas bordas da floresta.

Material selecionado: Aratuba, 14.V.1980, E. Nunes et al. (EAC 8621). Baturité, 1860, fl.,F.F. Allemão \& M. Cisneiros 473 (R). Guaramiranga, 8.IX.2007, fl., J.R. Lima 167 (EAC, RB). Mulungu, 29.VIII.1995, F.S. Cavalcanti et al. (EAC 23078). Pacoti, 17.VII.1997, L.W. Lima-Verde 2411 (EAC).

27. Senna spectabilis (DC.) H.S. Irwin \& Barneby, Mem. New York Bot. Gard. 35: 600. 1982.

27. 1 Senna spectabilis var. excelsa (Schrad.) H.S. Irwin \& Barneby, Mem. New York Bot. Gard. 35: 604. 1982.

Fig. 2l-n

Espécie arbórea reconhecida pelas folhas com muitos folíolos (aproximadamente 20) sem nectários extraflorais, inflorescência do tipo racemo com flores amarelas e frutos cilíndricos e pêndulos. Ocorre do México até a Argentina, sendo amplamente cultivada como ornamental no Neotrópico (Irwin \& Barneby 1982). Na Serra de Baturité foi encontrada em áreas de floresta ombrófila.

Material selecionado: Baturité, 10.IV.1909, fl., A. Ducke (MG 1953). Guaramiranga, 18.IV.2008, fl., J.R. Lima 511 (RB). Mulungu, 14.XI.2007, J.R. Lima 390 (EAC, RB).
28. Senna splendida (Vogel) H.S. Irwin \& Barneby, Mem. New York Bot. Gard. 35: 190. 1982.

28.1 Senna splendida var. gloriosa H.S. Irwin \& Barneby, Mem. New York Bot. Gard. 35: 192. 1982.

Fig. 2o-p

Arbusto caracterizado pelas folhas com dois pares de folíolos e um nectário extrafloral localizado entre os folíolos do primeiro par, flores com sépalas verdes e pétalas amarelas e frutos cilíndricos e carnosos. Distribui-se do Ceará até São Paulo, ocorrendo a oeste até o Piauí, Minas Gerais e Paraguai. É encontrada em bordas de floresta ombrófila densa atlântica e savana estépica. $\mathrm{Na}$ Serra de Baturité foi encontrada principalmente em áreas de floresta estacional, sendo também encontrada na floresta ombrófila.

Material selecionado: Aratuba, 15.V.1980, E. Nunes et al. (EAC 8632). Baturité, 1860, fl. e fr., F.F. Allemão \& M. Cisneiros 455 (R). Guaramiranga, 20.IX.2007, fl., J.R. Lima 210 (EAC, RB). Mulungu, 18.IX.2007, fl., J.R. Lima 161 (EAC, RB). Pacoti, 13.VII.1941, P. Bezerra 313 (EAC).

29. Senna trachypus (Benth.) H.S. Irwin \& Barneby, Mem. New York Bot. Gard. 35: 190. 1982.

Espécie arbustiva ou arvoreta reconhecida pela combinação de folhas com aproximadamente dez pares de folíolos, discolores e por apresentar nectários extraflorais entre todos os pares de folíolos. É encontrada do Maranhão até a Bahia, em áreas de savana estépica, floresta estacional e algumas vezes em áreas de savana. Na Serra de Baturité foi encontrada em áreas de floresta estacional.

Material examinado: Baturité, 17.V. 1959, A. Fernandes (EAC 1870).

30. Senna uniflora (Mill.) H.S. Irwin \& Barneby, Mem. New York Bot. Gard. 35: 258. 1982.

Espécie herbácea ou subarbustiva com folhas com cerca de quatro pares de folíolos e nectário extrafloral localizado próximo ou acima da metade do pecíolo, frequentemente entre o primeiro par de folíolos; os ramos, folhas e eixo da inflorescência são revestidos por tricomas hirsutos (amarelos a ferrugíneos). Planta invasora de ambientes úmidos, distribuindo disjuntamente entre o México e a América Central e o Nordeste do Brasil até Minas Gerais e Goiás (Irwin \& Barneby 1982). Na Serra de Baturité foi encontrada em áreas de floresta estacional.

Material selecionado: Baturité, 11.IV.1909, A. Ducke 1972 (RB). 


\section{Chave de identificação dos gêneros de Mimosoideae da Serra de Baturité}

1. Folhas sem nectários extraflorais.

2. Cálice com prefloração valvar; androceu com até 10 estames; fruto craspédio Mimosa

2'. Cálice com prefloração imbricada; androceu com mais de 10 estames; fruto legume ... Calliandra

1'. Folhas com nectários extraflorais.

3. Folhas pinadas Inga

3'. Folhas bipinadas.

4. Flores em espiga.

5. Folíolos alternos. Stryphnodendron

5'. Folíolos opostos ou subopostos.

6. Plantas armadas Piptadenia

6'. Plantas inermes Pityrocarpa

4'. Flores em glomérulos ou umbelas.

7. Cálice com prefloração imbricada Parkia

7'. Cálice com prefloração valvar.

8. Androceu com até 10 estames.

9. Árvores; fruto folículo; sementes com margem alada Anadenanthera

9'. Subarbustos; fruto legume; sementes não aladas Desmanthus

8'. Androceu com mais de 10 estames.

10. Estames livres ou fundidos apenas na base.

11. Frutos indeiscentes Vachellia

11'. Frutos deiscentes Senegalia

10'. Estames unidos formando um tubo.

12. Frutos indeiscentes.

13. Plantas inermes.

14. Flores pediceladas com estames bicolores (branco e vermelho ou rosa), fruto reto, oblongo-linear Samanea

14'. Flores sésseis com estames unicolores (brancos), fruto auriculiforme Enterolobium

13'. Plantas armadas Chloroleucon

12'. Frutos deiscentes.

15. Deiscência elástica, valvas arqueadas quando abertas .. Zapoteca

15'. Deiscência passiva, valvas espiraladas ou retas quando abertas 16

16. Frutos lenhosos, vermelhos internamente e válvas que enrolam após deiscência

Abarema

16'. Frutos não lenhosos, não vermelhos internamente, valvas retas após deiscência Albizia

Abarema Pittier, Arb. Legum.: 56. 1927.

Gênero com plantas arbóreas ou arbustivas, inermes, caracterizado pelas folhas bipinadas, frutos com endocarpo vermelho e sementes bicolores. Possui distribuição neotropical com 49 espécies, 30 para o Brasil (Iganci \& Morin 2009; Lewis \& Rico Arce 2005) sendo a floresta ombrófila densa Amazônica e Atlântica consideradas centros de diversidade para o gênero (Barneby \& Grimes 1996). Na Serra de Baturité foi encontrado apenas um táxon: Abarema jupunba var. jupunba.
31. Abarema jupunba (Willd.) Britton \& Killip, Ann. New York Acad. Sci. 35(3): 126. 1936.

31.1 Abarema jupunba (Willd.) Britton \& Killip var. jupunba

Fig. 3a-e

Árvore reconhecida por apresentar frutos com valvas espiraladas, margem ondulada e endocarpo vermelho. É encontrada nas Antilhas, Bolívia, Colômbia, Equador, Guiana Francesa, Guiana, Peru, Suriname, Venezuela e Brasil (AP, AM, MA, MG, PA, RR e do CE ao ES). Ocorre em áreas de floresta ombrófila densa amazônica e atlântica e 
savana (Barneby \& Grimes 1996). Na Serra de Baturité foi encontrada em áreas de floresta ombrófila acima de $600 \mathrm{~m}$.

Material examinado: Aratuba, 14.V.1980, P. Martins \& E. Nunes (RB 462052). Guaramiranga, 16.X.1993, M.R. Oliveira (EAC 20917). Mulungu, 13.XI.2007, fl., J.R. Lima 385 (EAC, RB). Pacoti, 12.II.1981, A. Fernandes (EAC 9652).

Albizia Durazz., Mag. Tosc. 3(4): 13-14. 1772.

Gênero caracterizado pelas espécies arbóreas, inermes, folhas bipinadas com nectários extraflorais, inflorescência do tipo glomérulo, flores pentâmeras, androceu polistêmone e monadelfo e frutos do tipo legume. Gênero pantropical com cerca de 120-140 espécies (Lewis et al. 2005). Na América do Sul são encontradas 14 espécies, a maior parte ocorrendo em florestas ombrófilas. Na Serra de Baturité é encontrada apenas uma espécie.

32. Albizia polycephala (Benth.) Killip ex Record, Trop. Woods 63: 6. 1940. Fig. 3f-j

Espécie arbórea, inerme, folhas com até sete pinas cada uma com aproximadamente 20 foliólulos, nectário extrafloral discóide e séssil, inflorescência glomeruliforme com flores brancas e os frutos do tipo legume. No Nordeste do Brasil é encontrada principalmente em áreas de savana estépica e florestas estacionais, sendo observada também em restingas no sul da Bahia e do Rio de Janeiro (Barneby \& Grimes 1996). Na Serra de Baturité foi encontrada em áreas de floresta ombrófila e estacional.

Material examinado: Baturité, 26.XII.1997, A.S.F. Castro(EAC 26004). Guaramiranga, 14.XI.2007, J.R. Lima 405 (EAC, RB); Mulungu, Sitio Jardim, 19.I.2003, fl., A. P. Silveira 633 (EAC); Pacoti, 13.XI.2007, J.R. Lima 353 (EAC, RB).

Anadenanthera Speg, Physis (Buenos Aires) 6: 313. 1923.

Gênero arbóreo reconhecido pela combinação de folhas bipinadas, pinas e folíolos opostos, nectário extrafloral alongado, inflorescência glomeruliforme, flores pentâmeras, brancas, androceu com dez estames, anteras, em geral, com glândulas apicais e frutos do tipo folículo. Gênero neotropical com apenas duas espécies, que ocorrem predominantemente em florestas estacionais e matas ciliares, sendo também encontrado em áreas de savana (Lewis et al. 2005). Na Serra de Baturité foi encontrada apenas uma espécie.
33. Anadenanthera colubrina (Vell.) Brenan, Kew Bull. 10: 182. 1955.

33.1 Anadenathera colubrina (Vell.) Brenan var. colubrina.

Fig. 3k-o

O táxon é facilmente reconhecido pelo folículo plano, com margens irregularmente contraídas entre as sementes. É encontrado na América do Sul, no nordeste da Argentina, na Bolívia até o sul do Equador e no Brasil, de Minas Gerais ao Maranhão, ocorrendo principalmente em áreas de florestas estacionais (Queiroz 2009). Na Serra de Baturité foi registrada em áreas de floresta ombrófila e estacional.

Material selecionado: Baturité, 22.I.2009, fl. e fr., J.R. Lima 700 (RB). Capistrano, 3.VIII.1993, J.B.L.P. Medeiros et al. (EAC 21600).

Calliandra Benth., J. Bot. (Hooker) 2(11): 138-141. 1840.

Gênero arbustivo caracterizado pelas folhas bipinadas sem nectários extraflorais, inflorescência do tipo glomérulo ou umbela e frutos com deiscência elástica e margens espessadas. Diferencia-se de Zapoteca, no entanto diferencia-se deste por apresentar glomérulos não globosos ou umbelas e folíolos cartáceos. Calliandra possui 132 espécies com distribuição neotropical (Barneby 1998), sendo encontrado principalmente em áreas de floresta estacional, savana estépica e campo rupestre (Lewis et al. 2005). Na Serra de Baturité foi encontrada apenas uma espécie.

34. Calliandra parvifolia (Hook. \& Arn.) Speg., Revista Argent. Agron. 1: 193. $1926 . \quad$ Fig. 3p-q

Espécie arbustiva facilmente reconhecida entre as espécies da Serra de Baturité por apresentar folhas sem nectários extraflorais, androceu polistêmone, monadelfo, estames com filetes com base branca e ápice avermelhado (até 12 estames por flor) e frutos com deiscência longitudinal elástica a partir do ápice. Na Serra de Baturité foi registrada em áreas de floresta ombrófila e estacional.

Material examinado: Aratuba, 14.V.1980, P. Martins \& E. Nunes (EAC 8620). Pacoti, 21.IX.2007, J.R. Lima 228 (EAC, RB).

Material adicional: MARANHÃO: 16.V.1979, fr., $A$. Fernandes \& P. Bezerra (RB 462059). 


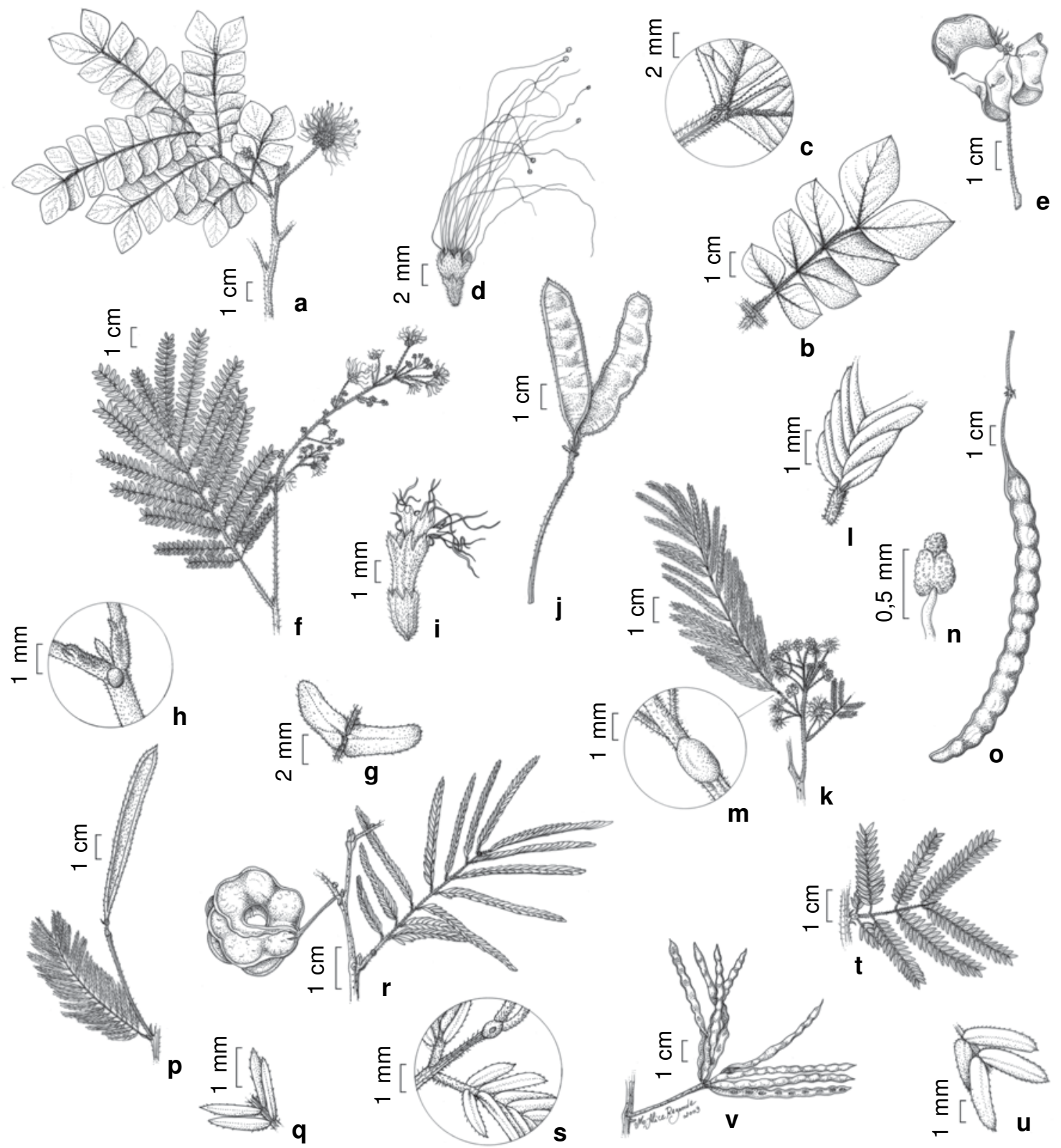

Figura 3 - a-e. Abarema jupunba (Willd.) Britton \& Killip var. jupunba - a. ramo com inflorescência; b. folha; c. detalhe do nectário extrafloral; d. flor (J.R. Lima 385); e. fruto (P. Martins \& E. Nunes - RB 462052). f-j. Albizia polycephala (Benth.) Barneby \& Grimes - f. ramo com inflorescência; g. detalhe dos folíolos; h. nectário extrafloral; i. flor; j. fruto (J.E. Leite 578). k-o. Anadenanthera colubrina (Vell.) Brenan var. colubrina-k. ramo com inflorescência; 1. detalhe da folha; m. nectário extrafloral; n. antera; o. fruto (J.R. Lima 700). p-q. Calliandra parvifolia(Hook. \& Arn.) Speg. - p. ramo com fruto; q. folíolos (P. Martins \& E. Nunes - EAC 8620). r-s. Chloroleucon acacioides (Ducke) Barneby \& J.W. Grimes - r. ramo com fruto; s. detalhe dos folíolos (J.R. Lima 218). t-v. Desmanthus virgatus Willd. - t. folha; u. folíolos; v. frutos (J.R. Lima 178).

Figure 3 - a-e. Abarema jupunba (Willd.) Britton \& Killip var. jupunba - a. branch with inflorescence; b. leaf; c. detail of the extrafloral nectary; d. flor; e. fruit. f-j. Albizia polycephala (Benth.) Barneby \& Grimes - f. branch with inflorescence; g. detail of the leaflets; h. extrafloral nectary; i. flower; j. fruit. k-o. Anadenanthera colubrina (Vell.) Brenan var. colubrina - k. branch with inflorescence; 1. detail of the leaf; m. extrafloral nectary; n. anther; o. fruit. p-q. Calliandra parvifolia (Hook. \& Arn.) Speg. - p. branch with fruit; q. leaflets. r-s. Chloroleucon acacioides (Ducke) Barneby \& J.W. Grimes - r. branch with fruit; s. detail of the leaflets. t-v. Desmanthus virgatus Willd. - t. leaf; u. leaflets; v. fruits. 
Chloroleucon (Benth.) Britton \& Rose, Trop. Woods 10: 24. 1927.

Gênero arbóreo ou arbustivo caracterizado por apresentar folhas bipinadas com nectários extraflorais próximo ao pecíolo, inflorescência glomeruliforme (homomórfica ou heteromórfica).
Gênero exclusivo das Américas, com dez espécies distribuídas do México e Antilhas até o sul do Brasil e norte da Argentina, ocorrendo em vegetações secas como a savana estépica e o chaco (Lewis et al. 2005). Na Serra de Baturité foram encontradas duas espécies.

\section{Chave de identificação das espécies deChloroleucon da Serra de Baturité}

1. Folhas com 3 a 5 pares de pinas; foliólulos de 2-3 $\mathrm{mm}$ de largura, glomérulo homomórfico.....

C. dumosum

1'. Folhas com 5 a 7 pares de pinas; foliólulos com até 1,5 $\mathrm{mm}$ de largura, glomérulo heteromórfico

C. acacioides

35. Chloroleucon acacioides (Ducke) Barneby \& J.W. Grimes, Mem. New York Bot. Gard. 74(1): 141. 1996.

Fig. 3r-s

Espécie arbustiva facilmente reconhecida pela presença de espinhos, em geral, pareados nos nós. Diferencia-se de C. dumosum por apresentar folíolos com até 1,5 mm e glomérulo heteromórfico. Espécie encontrada no Nordeste do Brasil e Guiana Francesa (Barneby \& Grimes 1996). A espécie ocorre principalmente em áreas de savana estépica e floresta estacional (Queiroz 2009). Na Serra de Baturité foi registrada em áreas de floresta estacional.

Material examinado: Baturité, 29.X.1939, fr., J.E. Leite 600 (RB). Pacoti, 20.IX.2007, fr., J.R. Lima 218 (EAC, RB).

36. Chloroleucon dumosum (Benth.) G.P. Lewis, Legumes Bahia: 165. 1987.

Espécie arbórea com três a cinco pinas por folha e nectários extraflorais sésseis próximos ao pecíolo, podendo ser encontrados também entre as pinas distais e glomérulo homomórfico. Espécie distribuída do Ceará ao Rio Grande do Norte e Bahia e Minas Gerais, em áreas de savana estépica e florestal estacional (Barneby \& Grimes 1996). Na Serra de Baturité foi registrada em áreas de floresta estacional.

Material examinado: Baturité, 11.IX.1908, A. Ducke (MG 1622). Guaramiranga, 20.VII.2004, A. P. Silveira (EAC 34297). Palmácia, 8.X.1980, fl., P. Martins etal. (EAC 8938).

Desmanthus Willd., Sp. Pl. 4(2): 1044. 1806.

Gênero herbáceo e arbustivo caracterizado pelos glomérulos heteromórficos, flores com estames brancos e frutos do tipo legume. Desmanthus tem distribuição dos Estados Unidos até o México e América Central, América do Sul (Lewis et al. 2005) com cerca de 24 espécies. Ocorre principalmente em florestas estacionais tropicais e subtropicais. $\mathrm{Na}$ Serra de Baturité foi encontrada apenas uma espécie.

37. Desmanthus virgatus (L.) Willd., Sp. Pl. 4(2): 1047. 1806.

Fig. 3t-v

Espécie reconhecida pela combinação de hábito arbustivo, glomérulo com flores brancas e legume séssil, linear e compresso. Espécie neotropical. Na Serra de Baturité foi registrada em áreas de floresta estacional.

Material examinado: Baturité, 17.V.1959, A. Fernandes (EAC 1878). Capistrano, 13.V.1980, fl., P. Martins et al. (EAC 8570). Mulungu, 19.IX.2007, J.R. Lima 178 (EAC, RB).

Enterolobium Mart., Flora 20(2): Beibl. 117. 1837.

Gênero arbóreo com folhas bipinadas, com nectários localizados próximos ao pecíolo, inflorescência glomeruliforme homomórfica, sendo facilmente reconhecido pelos frutos indeiscentes e auriculiformes. Enterolobium é um gênero neotropical com 11 espécies, distribuído do sul do México e Grandes Antilhas até o leste da Bolívia e Paraguai, norte da Argentina e Uruguai (Lewis et al. 2005). Na Serra de Baturité foi encontrada apenas uma espécie.

38. Enterolobium timbouva Mart., Flora 20 II. Beibl.: 128. 1837.

Fig. 4a-d

Espécie arbórea (até $20 \mathrm{~m}$ de altura) reconhecida pela combinação de folhas com até quatro pares de pinas (oito a doze foliólulos), glomérulos (axilares) com flores sésseis e frutos indeiscentes e auriculiformes. Ocorre do Maranhão até São Paulo, sendo encontrada também no Mato Grosso do Sul 


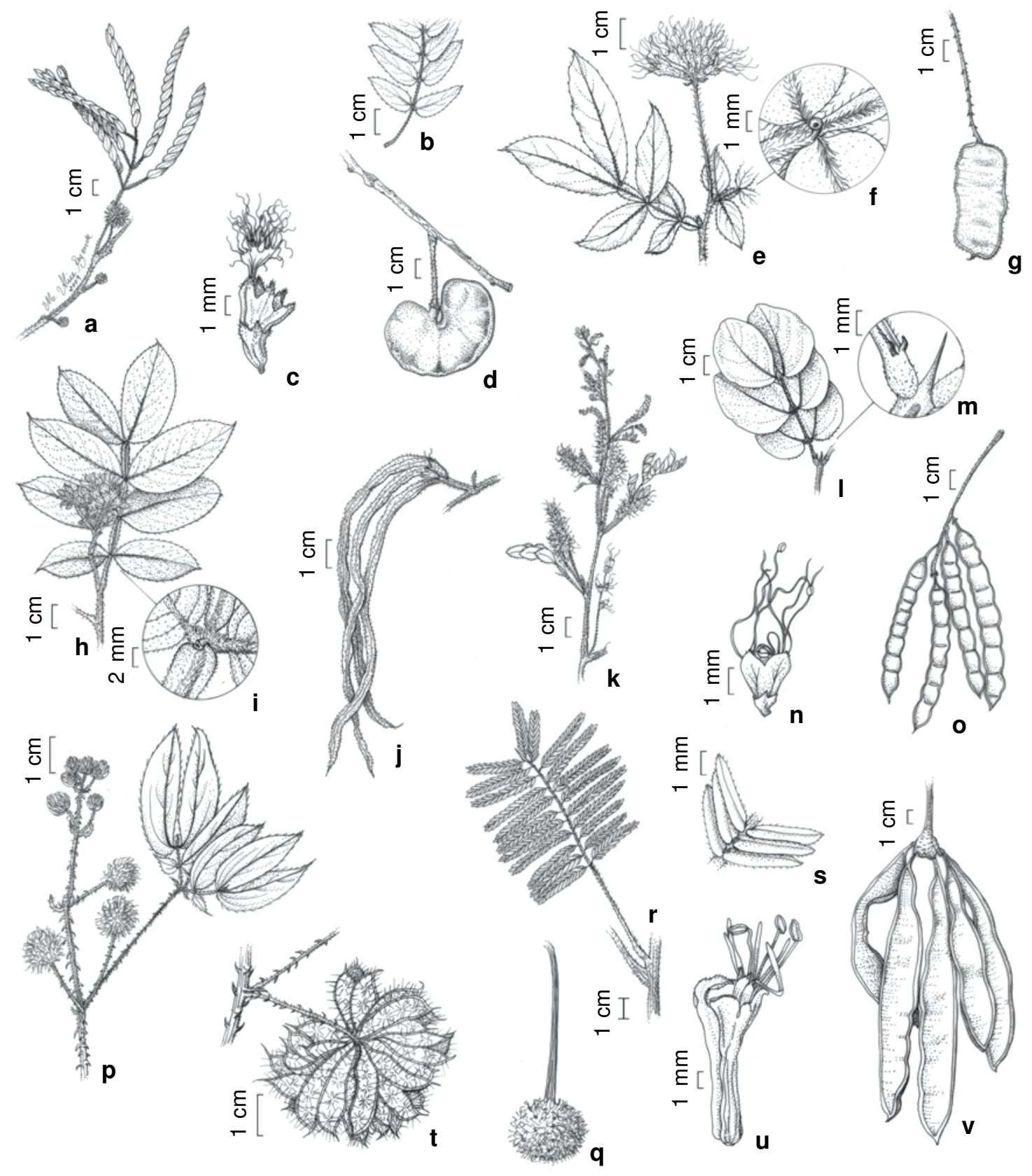

Figura 4 - a-d.Enterolobium timbouva Mart. - a. ramo com inflorescência; b. folíolos; c. flor (P.C. Gadelha-Neto 140); d. fruto ( P.C. Gadelha-Neto 189). e-g. Inga bollandii Sprague \& Sandwith - e. ramo com inflorescência; f. detalhe do nectário extrafloral (J.R. Lima 472); g. fruto (J.R. Lima 724). h-j.Inga ingoides (Rich.) Willd. - h. ramo com inflorescência; i. detalhe do nectário extrafloral (J.R. Lima 164); j. frutos (J.R. Lima 729). k-o. Mimosa caesalpiniifolia Benth. - k. ramo com inflorescência; 1. folha; m. detalhe da folha; n. flor (J.R. Lima 423); o. frutos (V. Gomes et al. - EAC 42352). p-q.Mimosa sensitiva L.var. sensitiva - p. ramo com inflorescência; q. frutos (J.R. Lima 649). r-v. Parkia pendula (Willd.) Benth. ex Walp. - r. folha; s. folíolos; t. inflorescência; u. flor; v. frutos (J.R. Lima 289).

Figure 4 - a-d. Enterolobium timbouva Mart. - a. branch with inflorescence; b. leaflets; c. flower; d. fruit. e-g. Inga bollandii Sprague \& Sandwith - e. branch with inflorescence; f. detail of the extrafloral nectary; g. fruit. h-j. Inga ingoides (Rich.) Willd. - h. branch with inflorescence; i. detail of the extrafloral nectary; j. frutits. k-o. Mimosa caesalpiniifolia Benth. - k. branch with inflorescence; 1. leaf; $\mathrm{m}$. detait of the leaf; $\mathrm{n}$. flower; o. fruits. p-q. Mimosa sensitiva L.var. sensitiva - p. branch with inflorescence; $\mathrm{q}$. fruits. r-v. Parkia pendula (Willd.) Benth. ex Walp. - r. leaf; s. leaflets; t. inflorescence; u. flower; v. fruits. 
e Paraguai, em áreas como savana estépica (Mesquista 1990). Na Serra de Baturité foi registrada em áreas de floresta estacional.

Material examinado: Baturité, 18.XI.1939, J.E. Leite 602 (RB).

Material adicional: PARAÍBA: Souza, 14.XI.1994, fl., P.C. Gadelha-Neto 140 (RB).

Inga Mill., Gard. Dict. Abr. (ed. 4): no. 2. 1754. Gênero arbóreo caracterizado pelas folhas pinadas com nectário extrafloral entre os folíolos de todos os pares, botões florais com prefloração valvar e androceu com muitos estames unidos em tubo. Inga é um gênero neotropical pertencente à tribo Ingeae, com cerca de 400 espécies das quais 140 são encontradas no Brasil, ocorrendo principalmente na floresta ombrófila densa amazônica, que é considerada o centro de diversidade do gênero, e na floresta ombrófila densa atlântica (Pennington 1997). Na Serra de Baturité foram encontradas sete espécies.

\section{Chave de identificação das espécies de Inga da Serra de Baturité}

1. Legume cilíndrico, ou quase, com faixas longitudinais expandidas.

2. Nectários foliares transversalmente comprimidos I. edulis

2'. Nectários foliares circulares a triangulares.

3. Botões florais alongados I. vera

3'. Botões florais arredondados I. ingoides

1'. Legume lateralmente comprimido sem faixas longitudinais expandidas.

4. Folhas exatamente com 2 pares de folíolos.

5. Raque foliar alada; estípula caduca I. marginata

5'. Raque foliar cilíndrica; estípula persistente I. laurina

4'. Folhas com mais de 3 pares de folíolos I. bollandii

39. Inga bollandii Sprague \& Sandwith, Bull. Misc. Inform. Kew 1926: 241-242. $1926 . \quad$ Fig. 4e-g Arvoreta caracterizada pelas folhas, em geral, com mais de três pares de folíolos, o par terminal elíptico e par basal ovado, inflorescência axilar, racemo congesto, cálice e corola verdes, androceu com até 60 estames brancos e frutos comprimidos lateralmente sem faixas longitudinais expandidas. Espécie encontrada apenas no Ceará e Sergipe, em áreas de floresta ombrófila densa atlântica acima de $800 \mathrm{~m}$ de altitude (Pennington 1997). $\mathrm{Na}$ Serra de Baturité foi registrada apenas em áreas de floresta ombrófila.

Material selecionado: Aratuba, 15.V.1980, fl.,E. Nunes et al. (EAC 8636). Guaramiranga, 20.VII.2003, fr., V. Gomes et al. 474 (EAC). Mulungu, 29.VIII.1995, F.S. Cavalcanti (EAC 23079). Pacoti, 10.VIII.1978, M.A. Figueiredo (EAC 4408). Serra de Baturité, 12.VIII.1908, fl. e fr., A. Ducke (RB16741).

40. Inga edulis Mart., Flora 20 (2): Beibl. 113-114. 1837.

Espécie arbórea reconhecida pelos frutos cilíndricos, nectários foliares sésseis comprimidos transversalmente e frutos com faixas longitudinais expandidas. Encontrada em toda região tropical da América do Sul, exceto em áreas áridas do Nordeste e Planalto Central do Brasil (Pennington 1997), ocorrendo no Brasil do Ceará a até Santa Catarina. $\mathrm{Na}$ Serra de Baturité foi registrada apenas em áreas de floresta ombrófila.

Material examinado: Aratuba, 9.IX.2007, J.R. Lima 250 (EAC, RB). Guaramiranga, 13.XI.2007, J.R. Lima 131 (EAC, RB).

41. Inga ingoides (Rich.) Willd., Sp. Pl. Editio quarta 4(2): 1012.1806.

Fig. $4 \mathrm{~h}-\mathrm{j}$

Espécie arbórea (até $20 \mathrm{~m}$ de altura) reconhecida pela combinação de legume cilíndrico com faixas longitudinais expandidas, nectários foliares circulares a triangulares e botões florais arredondados. Espécie ocorre nas Antilhas Menores e região tropical da América do Sul (Pennington 1997), no Brasil ocorre em todo Nordeste e Minas Gerais (Garcia 1998). Na Serra de Baturité foi registrada tanto em áreas de floresta ombrófila como de floresta estacional.

Material examinado: Baturité, 26.XII.1997, A.S.F. Castro 494 (EAC). Guaramiranga, 28.XII.2007, fl., J.R. Lima 164 (EAC, RB). Mulungu, 12.IX.2007, J.R. Lima 189 (EAC, RB). 
42. Inga laurina (Sw.) Willd., Sp. Pl. Editio quarta 4(2): 1018. 1806.

Espécie arbórea semelhante a I. marginata, mas se diferencia desta por apresentar raque foliar cilíndrica e estípula persistente. I. laurina é amplamente distribuída no Neotrópico (Pennington 1997), sendo encontrada em quase todos os estados do Brasil, tendo seu limite sul no Paraná e alcançando a Argentina e Paraguai (Garcia 1998). Na Serra de Baturité foi registrada apenas em áreas de floresta ombrófila.

Material selecionado: Baturité, 10.IX.1908, fl., A. Ducke (MG 1618). Guaramiranga, 13.XI.2007, V. Gomes 1001 (EAC).

43. Inga marginata Willd., Sp. Pl. 4(2): 1015. 1806. Espécie arbórea semelhante a I. laurina, mas diferencia-se desta por apresentar raque foliar alada e estípula caduca. I. marginata ocorre do Sul do México até extremo sul do Brasil e norte da Argentina (Pennington 1997). Na Serra de Baturité foi registrada em áreas de floresta ombrófila.

Material selecionado: Guaramiranga, Pico Alto, 8.X.2007, J.R. Lima 246 (EAC, RB).
44. Inga vera Willd., Sp. Pl. 4(2): 1010-1011. 1806. 44.1 Inga vera subsp. affinis (DC.) T.D. Penn., Gen. Inga: Bot.: 7161997

Árvore semelhante a I. ingoides, mas diferenciase pelos botões florais alongados e não arredondados como em I. ingoides. Distribuída na América do Sul tropical da Colômbia ao Uruguai (Pennington 1997). $\mathrm{Na}$ Serra de Baturité foi registrada tanto em áreas de floresta ombrófila como de floresta estacional.

Material examinado: Guaramiranga, 23.VII.2008, M.O.T. Menezes 98 (EAC). Baturité, X.1937, fl., J.E. Leite (RB 44715).

\section{Mimosa L., Sp. Pl. 1: 516-523. 1753.}

Mimosa possui espécies com hábito arbóreo, arbustivo, subarbustivo e herbáceo com inflorescência espiciforme ou glomeruliforme, androceu com até dez estames e fruto do tipo craspédio. Gênero pantropical, porém predominante no Neotrópico, com cerca de 490510 espécies, das quais 350 são endêmicas da América do Sul. São encontradas em áreas de florestas tropicais e subtropicais, savana estépica, savana e desertos (Barneby 1991; Lewis et al. 2005). Mimosaé o gênero de Leguminosae mais diverso da Serra de Baturité com 15 espécies (Lima et al. dados não publicados).

\section{Chave de identificação das espécies de Mimosa da Serra de Baturité}

1. Flores em espigas.

2. Flores róseas, pentâmeras M. invisa

2'. Flores brancas, tetrâmeras ou trímeras.

3. Folíolos lineares, flores tetrâmeras.

4. Ramos com glândulas resinosa e face abaxial dos folíolos com pontuações

4'. Ramos eglandulares e face abaxial dos folíolos sem pontuações. ... tenuiflora

5. Folíolos com nervuras secundárias conspícuas M. acustistipula

5'. Folíolos sem nervuras secundárias ou inconspícuas M. arenosa

3'. Folíolos obovais, flores trímeras M. caesalpiniifolia

1'. Flores em glomérulos.

6. Flores róseas.

7. Flores diplostêmones.

8. Tricomas glandulares presentes nos ramos e folhas. M. somnians

8'. Tricomas glandulares ausentes nos ramos e folhas.

9. Folhas com mais de 8 pares de folíolos.

10. Artículos do fruto com superfície glabra M. paraibana

10'. Artículos do fruto com superfície híspida M. pigra

9'. Folhas com até 3 pares de folíolos M. camporum

7'. Flores isostêmones.

11. Pinas com mais de 3 pares de pina; craspédio com replo contínuo M. quadrivalvis

11'. Pinas com 2 pares de pina; craspédio com replo não contínuo.

12. Acúleos formando séries longitudinais nas costas dos ramos M. sensitiva 12'. Acúleos sem esse padrão M. ursina 
6'. Flores brancas.

13. Folíolos lineares

M. bimucronata

13'. Folíolos oblongos.

14. Replo com acúleos; folíolos craspedódromas

M. ceratonia

14'. Replo sem acúleos; folíolos broquidódromas M. laticifera

45. Mimosa acustistipula (Mart.) Benth., J. Bot. (Hooker) 4(31): 391. 1841.

45.1 Mimosa acutistipula (Mart.) Benth. var. acutistipula

Arbusto (até $4 \mathrm{~m}$ de altura) semelhante a $M$. arenosa, porém diferencia se desta por apresentar folíolos com nervuras secundárias inconspícuas $(M$. arenosa possui nervuras secundárias conspícuas). Táxon encontrado do Ceará a Bahia, principalmente em áreas de savana estépica (Barneby 1991). Na Serra de Baturité foi encontrada em áreas de floresta estacional. Material selecionado: Baturité, 1937, fl. e fr., J.E. Leite 580 (RB).

46. Mimosa arenosa (Willd.), Encycl., Suppl. 1(1): 66. 1810.

46.1 Mimosa arenosa (Willd.) Poir. var. arenosa

Arbusto apresentando ramos normalmente com acúleos nos internós, folhas sem nectários extraflorais e inflorescência espiciforme com flores brancas. Espécie distribuída do Ceará a Minas Gerais e em áreas secas da costa da Venezuela (Barneby 1991). Na Serra de Baturité foi encontrada em áreas de floresta estacional. Material selecionado: Capistrano, 5.VIII.1993,J.B.L.P. Medeiros et al. (EAC 21597). Mulungu, 19.IX.2007, J.R. Lima 192 (EAC, RB).

47. Mimosa bimucronata (DC) Kuntze, Revis. Gen. Pl. 1: 198. 1891.

\subsection{Mimosa bimucronata (DC.) Kuntze var. bimucronata}

Arbusto ou arvoreta reconhecida pela combinação de inflorescência glomeruliforme com flores brancas e folíolos lineares. No Brasil ocorre no Ceará, de Alagoas ao Rio Grande do Sul, e da Bahia a Brasília e de maneira disjunta no Paraguai (Barneby 1991). Na Serra de Baturité foi encontrada em áreas de floresta ombrófila.

Material examinado: Guaramiranga, 4.X.1990, E. Nunes et al. (EAC 17140). Pacoti, 20.VII.1991, E. Nunes et al. (EAC 17854).

48. Mimosa caesalpiniifolia Benth., J. Bot. (Hooker) 4(31): 392. 1841. Fig. 4k-o

Espécie arbórea facilmente diferenciada das outras espécies de Mimosa da serra pela combinação de hábito arbóreo, folíolos largos, obovais e nervação craspedódroma. Distribuída do Maranhão a Pernambuco (Barneby 1991). Na Serra de Baturité foi encontrada em áreas de floresta estacional.

Material selecionado: Baturité, 19.III.2008, fl., J.R. Lima 423 (RB). Capistrano, Fazenda Araçanga, 8.VIII.1994, J.B.L.P. Medeiros (EAC 21590). Mulungu, 12.II.2004, fr., V. Gomes et al. (EAC 42352).

49. Mimosa camporum Benth., J. Bot. (Hooker) 2(11): 130.1840.

Mimosa camporum é uma espécie herbácea reconhecida pela combinação de inflorescência glomeruliforme com flores róseas e folhas com até 3 pares de folíolos. Espécie neotropical amplamente distribuída em várias formações vegetacionais. Na Serra de Baturité foi encontrada em áreas de floresta estacional.

Material examinado: Baturité, 5.V.1939, fl. e fr., J.E. Leite 597 (RB).

50. Mimosa ceratonia L., Sp. Pl. 1: 523. 1753.

50.1 Mimosa ceratonia var. pseudo-ovata (Taub.) Barneby

Subarbusto reconhecido pela combinação de inflorescência glomeruliforme com flores brancas e replo com acúleos. Segundo Barneby (1991), a espécie encontrada no Brasil do Ceará a Santa Catarina, em áreas de restingas e matas úmidas. Na Serra de Baturité foi encontrada em áreas de floresta ombrófila.

Material examinado: Baturité, 10.IX.1993, M.R.L. Oliveira (EAC 23523). Guaramiranga, 18.VII.1908, fl., A. Ducke (MG 1338).

51. Mimosa invisa Mart. ex Colla, Herb. Pedem. 2: 255. 1834.

51.1 Mimosa invisa Mart. ex Colla var.invisa

Mimosa invisa é facilmente reconhecida por apresentar inflorescências espiciformes com flores róseas, androceu com cinco estames, além dos ramos armados com séries longitudinais de acúleos, localizados sobre costelas discolores. Espécie invasora bem distribuída na América do Sul, da Venezuela até o Paraguai (Barneby 1991). Na Serra de Baturité foi encontrada em áreas de floresta ombrófila. Material examinado: Aratuba, 14.V.1980, P. Martins et al. (EAC 8611). 
52. Mimosa laticifera Rizzini \& A. Mattos, Arch. Jard. Bot. Rio de Janeiro 18: 73. 1965.

Espécie arbórea ou arbustiva reconhecida pela combinação de folhas broquidódromas, folíolos oblongos, inflorescência glomeruliforme com flores brancas e replo sem acúleos. Segundo Barneby (1991), M. laticifera era encontrada no Brasil apenas no Mato Grosso, Mato Grosso do Sul, Minas Gerais e São Paulo, em áreas de Savanas e Savanas florestadas (Barneby 1991), tendo sido registrada no Ceará pela primeira vez. Na Serra de Baturité foi encontrada em áreas de floresta estacional.

Material examinado: Baturité, 16.III.1928, fr.,J.E. Leite 582 (RB).

53. Mimosa paraibana Barneby, Mem. New York Bot. Gard. 65: 171. 1991.

Mimosa paraibana é uma espécie arbustiva com ramos com acúleos recurvados e flores tetrâmeras róseas. É semelhante à $M$. pigra, no entanto M. paraibana apresenta os artículos do fruto com superfície glabra e não híspida como em M. pigra. É endêmica do Nordeste, ocorrendo do Maranhão até Pernambuco, principalmente em áreas de florestas estacionais e savana estépica (Barneby 1991). Na Serra de Baturité foi encontrada em áreas de floresta estacional.

Material examinado: Guaramiranga, 4.X.1990, A.V. Custódio \& M.A. Oliveira (EAC 17139).

\section{Mimosa pigra L., Cent. Pl. I: 13-14. 1755.}

Espécie arbustiva facilmente reconhecida por apresentar inflorescência glomeruliforme com flores róseas e ramos, folhas e frutos cobertos por indumento híspido. $M$. pigra tem distribuição pantropical sendo encontrada em áreas de floresta ombrófila densa atlântica (Barneby 1991). Na Serra de Baturité foi encontrada em áreas de floresta estacional. Material examinado: Guaramiranga, 7.I.1995, M.A. Figueiredo (EAC 23002).

55. Mimosa quadrivalvis L., Sp. Pl. 1: 522.1753. 55.1 Mimosa quadrivalvis var. leptocarpa (DC.) Barneby, Mem. New York Bot. Gard. 65: 298. 1991.

Mimosa quadrivalvis possui hábito subarbustivo, inflorescência glomeruliforme com flores pentâmeras e róseas e diferencia-se de todas as outras espécies de Mimosa por apresentar as valvas do fruto inteiras, não se dividindo em artículos monospérmicos. Táxon bem distribuído na América tropical e subtropical (Barneby 1991). Na Serra de Baturité foi encontrada em áreas de floresta estacional. Material examinado: Baturité, IX.1937, J.E. Leite 594 (RB).
56. Mimosa sensitiva L., Sp. Pl. 1: 518. 1753. 56.1 Mimosa sensitiva L. var. sensitiva

Fig. 4. p-q

Subarbusto facilmente reconhecido por apresentar apenas dois pares de folíolos por pina, sendo os mais internos atrofiados, inflorescência glomeruliforme com flores tetrâmeras róseas e o craspédio hirsuto. Amplamente distribuído do Nordeste do Brasil até o Pará e Mato Grosso do Sul e no planalto das Guinas e Venezuela, sendo comum em várias formações vegetacionais (Barneby 1991). $\mathrm{Na}$ Serra de Baturité foi encontrada tanto em áreas de floresta estacional como de floresta ombrófila. Material examinado: Baturité, VII.1937, fr., J.E. Leite 595 (RB). Pacoti, 10.VII.2008, fl. e fr., J.R. Lima 649 (RB).

57. Mimosa somnians Humb. \& Bonpl. ex Willd., Sp. Pl. 4(2): 1036. 1806.

57.1 Mimosa somnians Humb. \& Bonpl. ex Willd. subsp. somnians

Subarbusto reconhecido pela combinação de ramos e folhas (três a cinco pinas) com tricomas glandulares e inflorescência glomeruliforme com flores tetrâmeras róseas. Amplamente distribuído na América tropical e subtropical, ocorrendo do sul do México até o norte da Argentina, encontrada com frequência em ambientes degradados e em beira de estradas (Barneby 1991). Na Serra de Baturité foi encontrada em áreas de Floresta Estacional.

Material examinado: Baturité, 9.IX.1939, fr., J.E. Leite 591 (RB).

58. Mimosa tenuiflora (Willd.) Poir., Encycl. (Lamarck), Suppl. 1: 82. 1811.

Espécie arbustiva apresentando inflorescência espiciforme com flores tetrâmeras brancas e androceu com oito estames. Entre as espécies de Mimosa com inflorescência branca, $M$. tenuiflora é facilmente reconhecida por apresentar ramos e folhas novas com resinosa e pontuações glandulares escuras na face abaxial dos folíolos. M. tenuiflora é encontrada no Nordeste do Brasil, norte da Venezuela e Colômbia e sul do México, Honduras e El Salvador (Barneby 1991). Na Serra de Baturité foi encontrada em áreas de floresta estacional.

Material examinado: Baturité, 19.X.1979, A.J. Castro et al. (EAC 7166). Capistrano, 27.X.1994, J.B.L.P. Medeiros et al. (EAC 28539). Guaramiranga, 14.XI.2007, J.R. Lima 396 (EAC, RB).

59. Mimosa ursina Mart., Flora 21: 56. 1838.

Espécie herbácea facilmente reconhecida por apresentar apenas um par de folíolos e craspédios 
com artículos dilatados com acúleos na parte central. Espécie encontrada em áreas antropizadas no Nordeste do Brasil e na América Central (Barneby 1991). Na Serra de Baturité foi encontrada em áreas de floresta estacional.

Material examinado: Mulungu, 18.IV.2008, fr., J.R. Lima 542 (RB).

Parkia R. Br., Narr. Travels Africa: 234. 1826.

Árvores inermes, com folhas bipinadas, opostas ou alternas e flores com prefloração do cálice imbricada. Gênero pantropical com 34 espécies, sendo a floresta ombrófila densa amazônica considerada um centro de diversidade para o gênero (Ducke \& Black 1953). É encontrado em florestas ombrófilas, estacionais, savanas e restingas (Lewis et al. 2005). Na Serra de Baturité foi encontrada apenas uma espécie.

60. Parkia pendula (Willd.) Benth. ex Walp., Repert. Bot. Syst. 5(4): 577. $1846 . \quad$ Fig. 4r-v

Árvore de grande porte (até $40 \mathrm{~m}$ de altura) com copa larga e aplainada. A inflorescência é um capítulo com pedúnculo longo e pêndulo. Os folículos produzem uma grande quantidade de resina que retém as sementes maduras, após a abertura das valvas (Hopkins \& Hopkins 1983). É encontrada na América Central e América do Sul (Hopkins 1986), ocorrendo em mata de terra firme na região floresta ombrófila densa amazônica e na floresta ombrófila densa atlântica, sendo considerada a espécie de mais ampla distribuição do gênero. Na Serra de Baturité foi encontrada apenas em áreas a barlavento acima de $600 \mathrm{~m}$.

Material examinado: Guaramiranga, 5.XI.2002, A.P. Silveira et al. 379 (EAC). Pacoti, 10.X.2007, J.R. Lima 289 (EAC, RB). Serra de Baturité, 1.VI.1972, D. AndradeLima 4432 (IPA).

Piptadenia Benth., J. Bot. (Hooker) 2(11): 135.1840. Gênero arbóreo, arbustivo ou lianescente, com folhas bipinadas, nectários foliares, em geral, peciolar, inflorescência espiciforme, flores pentâmeras, androceu com até 10 estames e fruto do tipo legume. Piptadenia tem cerca de 25 espécies com distribuição neotropical (Jobson \& Luckow 2007; Lewis et al. 2005). É encontrado em Floresta ombrófila densa atlântica, florestas estacionais tropicais e subtropicais e savana estépica. Na Serra de Baturité foram encontradas duas espécies.

\section{Chave de identificação das espécies de Piptadenia da Serra de Baturité}

1. Ramos com acúleos internodais, pecíolo com nectário oblongo ………............................ P. stipulacea

1'. Ramos com acúleos nodais, pecíolo com nectário discóide P. viridiflora

61. Piptadenia stipulacea (Benth.) Ducke, Arq. Jard. Bot. Rio de Janeiro 5: 126. $1930 . \quad$ Fig. 5a-d Espécie arbórea caracterizada pela presença de acúleos internodais, inflorescência axilar, flores pentâmeras comaproximadamente $5 \mathrm{~mm}$ de comprimento, estames amarelados e fruto do tipo legume. Espécie encontrada no Nordeste do Brasil (Ceará à Bahia), considerada endêmica da savana estépica (Queiroz 2009), no entanto, na Serra de Baturité foi encontrada em áreas de florestas estacionais e ombrófilas.

Material examinado: Baturité, 10.IV.1909, fl., A. Ducke (MG 1950). Capistrano, 8.VIII.1994, fl., J.B.L.P. Medeiros et al. 138 (EAC). Mulungu, 12.XI.2007,J.R. Lima 343 (EAC, RB). Pacoti, 9.X.1980, fl. e fr., E. Nunes et al. (EAC 8976).

62. Piptadenia viridiflora (Kunth) Benth., J. Bot. (Hooker) 4(31): 337. 1841.

Espécie arbórea, facilmente reconhecida pela presença de estípulas nodais pareadas modificadas em espinhos, ramos revestidos por lenticelas brancas e nectários extraflorais discóides e inflorescência com flores com ca. de $10 \mathrm{~mm}$. Espécie ocorrente no Nordeste Brasileiro e Argentina e Paraguai em áreas de savana estépica e florestas estacionais (Prado \& Gibbs 1993). Na Serra de Baturité foi encontrada em áreas de floresta estacional.

Material examinado: Aratuba, 9.X.2007, fl.,J.R. Lima 255 (EAC, RB). Capistrano, 27.X.1994, J.B.L.P. Medeiros (EAC 45061). Mulungu, 19.IX.2007, J.R. Lima 172 (EAC, RB).

Pityrocarpa (Benth.) Britton \& Rose, N. Amer. Fl. 23(3): 190. 1928.

Árvores inermes, em geral, com estípulas persistentes e flores com pétalas recurvadas. Pityrocarpa é um gênero neotropical, segregado de Piptadenia, com três espécies (Jobson \& Luckow 2007). Estes autores encontraram evidências de que Piptadenia é um gênero polifilético e sugeriram sua divisão em três gêneros diferentes. Propondo a transferência das espécies do clado Pityrocarpa para o gênero Pityrocarpa. 

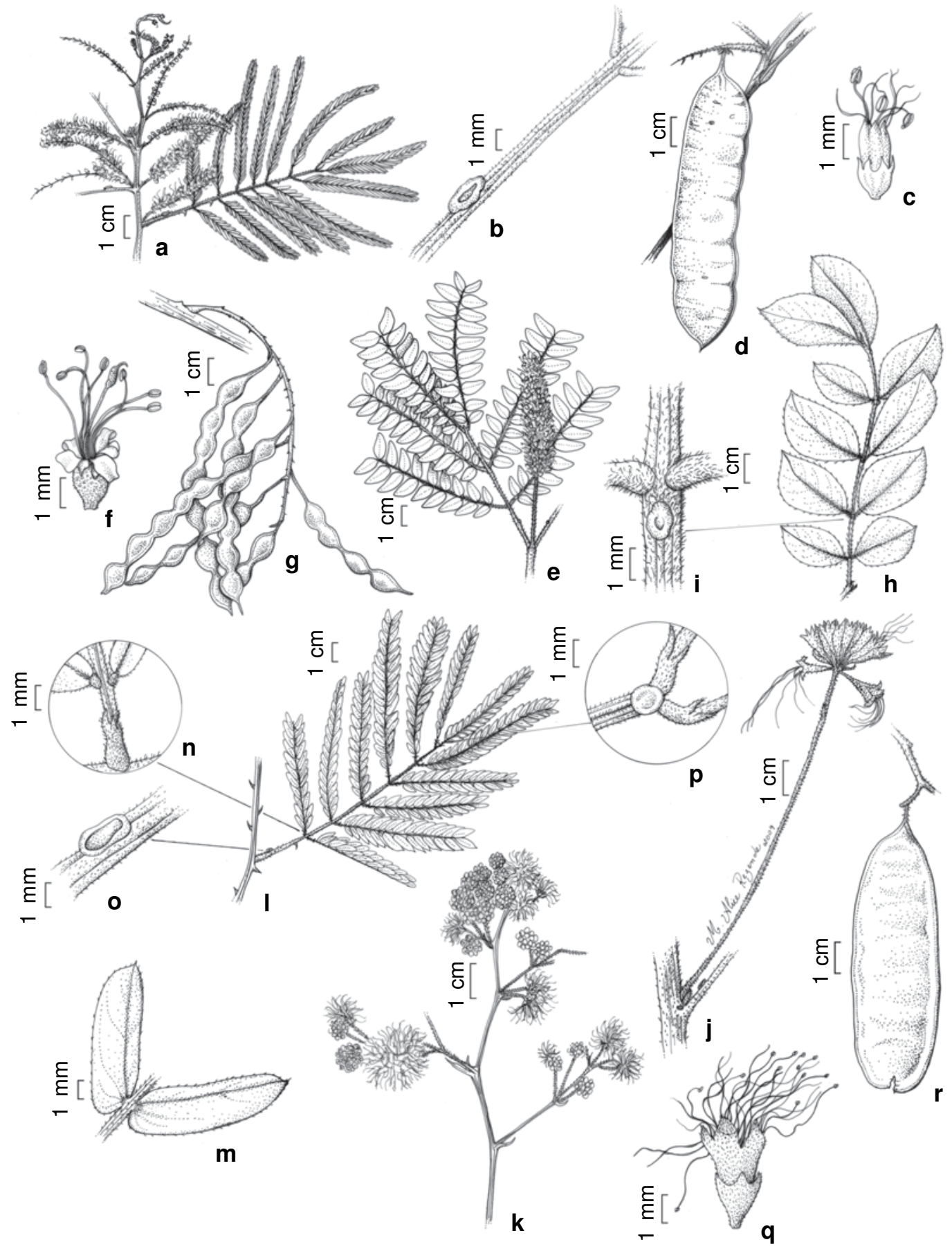

Figura 5-a-d. Piptadenia stipulacea (Benth.) Ducke-a. ramo com inflorescência; b. ramo com nectário extrafloral; c. flor; d. fruto (J.R. Lima 217). e-g. Pityrocarpa moniliformis (Benth.) Luckow \& R.W. Jobson-e. ramo com inflorescência; f. flor (J.R. Lima 424); g. frutos (H.C. Lima 3957). h-j. Samanea saman (Jacq.) Merr. - h. folha; i. detalhe da folha; j. inflorescência (CAC/2361 - RB 351138). k-r.Senegalia polyphylla (DC.) Britton \& Rose-k. inflorescências; l. folha; $m$. folíolos; $n$. detalhe da folha; o. nectário extrafloral; p. detalhe da folha; q. flor (J.R. Lima 712); r. fruto (B.A.S. Pereira \& E.C. Lopes- RB 351195). Figure 5 - a-d. Piptadenia stipulacea (Benth.) Ducke - a. branch with inflorescence; b. branch with extrafloral nectary; c. flower; d. fruit. e-g. Pityrocarpa moniliformis (Benth.) Luckow \& R.W. Jobson - e. branch with inflorescence; f. flower; g. fruits. h-j. Samanea saman (Jacq.) Merr. - h. leaf; i. detail of the leaf; j. inflorescence. k-r. Senegalia polyphylla (DC.) Britton \& Rose - k. inflorescences; 1. leaf; m. leaflets; $n$. detail of the leaf; o. extrafloral nectary; p. detail of the leaf; q. flor; r. fruit. 
63. Pityrocarpa moniliformis (Benth.) Luckow \& R.W. Jobson, Syst. Bot. 32(3): 573. 2007.

Fig. 5e-g

Espécie arbórea, inerme, nectário extrafloral presente no pecíolo, inflorescência axilar do tipo espiciforme (isoladas ou pareadas), flores pentâmeras e estames com coloração esverdeada. $P$. moniliformis é facilmente reconhecida pelo folículo moniliforme, regularmente constrito entre as sementes. É encontrada no Nordeste do Brasil, sendo comum em áreas sobre embasamento sedimentar, ocorrendo ocasionalmente em áreas cristalinas, sendo encontrada também na Venezuela (Queiroz 2006b). Na Serra de Baturité foi encontrada em áreas de florestas ombrófilas.

Material selecionado: Baturité, 19.III.2008, fl., J.R. Lima 424 (RB).

Material adicional: BAHIA: Chapada Diamantina, 11.IX.1990, fl. e fr., H.C. Lima et al. 3957 (RB).

Samanea (Benth.) Merr., J. Wash. Acad. Sci. 6(2): 46. 1916.

Gênero arbóreo, inerme, caracterizado pelas folhas bipinadas, nectários extraflorais próximos à base do pecíolo, inflorescência umbeliforme, heteromórfica, flores pediceladas, androceu com mais dez estames bicolores unidos entre si e fruto indeiscente com pericarpo espessado e lenhoso. Gênero neotropical com apenas três espécies ocorrendo em florestas tropicais estacionais e ombrófilas (Barneby \& Grimes 1996). Na Serra de Baturité foi encontrada apenas uma espécie.
64. Samanea saman (Jacq.) Merr., J. Wash. Acad. Sci. 6(2): 47. 1916.

Fig. 5h-j

Espécie reconhecida pela combinação dos caracteres ramos inermes, folhas bipinadas, inflorescência umbeliforme (heteromórfica), flores pediceladas e estames bicolores (branco e vermelho ou rosa). É uma espécie neotropical distribuída desde o México até a Bolívia, sendo comum em florestas estacionais (Barneby \& Grimes 1996). Na Serra de Baturité foi encontrada em áreas de florestas ombrófilas.

Material examinado: Pacoti, 12.XI.2007, J.R. Lima 368 (RB).

Material adicional: MATO GROSSO DO SUL: Miranda, 15.X.1988, fl., CAC/2361 (RB 351138).

Senegalia Raf., Sylva Tellur.: 119. 1838.

Gênero arbóreo, arbustivo ou lianescente caracterizado pelos ramos, em geral, com acúleos, folhas bipinadas com nectários extraflorais, inflorescência espiciforme ou glomeruliforme, flores pentâmeras, polistêmones, estames livres e fruto do tipo legume. Senegalia tem distribuição pantropical, com aproximadamente 203 espécies. Nas Américas é encontrado em florestas estacionais e ombrófilas. Senegalia é um gênero segregado de Acacia s.l. que, segundo sua circunscrição atual (Orchard \& Maslin 2003), este último não apresenta representantes nas Américas, porém Rico-Arce (2007) não concorda com tal posicionamento e adota o nome Acacia para as espécies neotropicais. Na Serra de Baturité foram encontradas quatro espécies.

\section{Chave de identificação das espécies deSenegalia da Serra de Baturité}

1. Arbusto escandente; acúleos em quatro séries longitudinais nos ramos S. martiusiana

1'. Arbusto ou arvoreta; acúleos dispersos ao longo dos ramos.

2. Folhas com 10 a 15 pares de pinas; nectário séssil, glomérulos $\leq 6 \mathrm{~mm}$ diâmetro.

3. Folhas com 12 a 15 pares de pinas; corola glabra S. tenuifolia

3'. Folhas com 9 a 10 pares de pinas; corola pubescente. S. polyphylla

2'. Folhas com 3 a 8 pares de pinas; nectário peltado, glomérulos $>6$ mm diâmetro S. riparia

65. Senegalia martiusiana (Steud.) Seigler \& Ebinger, Nomencl. Bot. 2 (9): 148. 1841.

Espécie arbustiva escandente, facilmente reconhecida por apresentar ramos angulosos com os acúleos distribuídos em quatro séries, enquanto que as demais espécies de Senegalia da Serra de Baturité possuem acúleos dispersos ao longo dos ramos. Segundo Bocage (2005), a espécie é encontrada de Pernambuco ao norte de Minas Gerais, sendo primeiro registro para o Ceará. $\mathrm{Na}$ Serra de Baturité foi encontrada em áreas de florestas ombrófilas.

Material examinado: Guaramiranga, 18.IX.2007, J.R. Lima 166 (RB). 
66. Senegalia polyphylla (DC.) Britton \& Rose, Ann. New York Acad. Sci. 35(3): 142. 1936.

Fig. 5k-r

Espécie representada por arbustos ou arvoretas. É semelhante a $S$. tenuifolia, porém diferencia-se por apresentar folhas menores ( 9 a 10 pares de pinas) e corola pubescente. S. polyphylla é distribuída na América Central e América do Sul, da Venezuela, Brasil, Paraguai até Argentina (Bocage 2005). Na Serra de Baturité foi encontrada em áreas de florestas estacionais e ombrófilas.

Material examinado: Baturité, 9.IV.1909, fl. e fr., A. Ducke (MG 1941). Guaramiranga, 23.I.2009, fl., J.R. Lima 712 (RB). Pacoti, 20.IX.2007, J.R. Lima 206 (EAC, RB).

Material adicional: MINAS GERAIS: Unaí,31.VIII.1990, fr., B.A.S. Pereira \& E.C. Lopes (RB 351195).

67. Senegalia riparia (Kunth) Britton \& Rose, Ann. New York Acad. Sci. 35(3): 144. 1936.

Espécie arbustiva que se diferencia das outras espécies de Senegalia da área por apresentar folhas com pequeno número de pinas ( 3 a 8 pares), nectário peltado, inflorescência glomeruliforme, flores com estames brancos e ovário pubescente e fruto do tipo legume. Ocorre na América do Sul e, no Brasil, é encontrada no Amazonas, Bahia, Piauí, Ceará e Minas Gerais (Bocage 2005). No semiárido brasileiro é encontrada em áreas de savana estépica, vegetação arbustiva caducifólia não espinhosa e floresta estacional (Bocage 2005). $\mathrm{Na}$ Serra de Baturité é encontrada em áreas de florestas estacionais.

Material examinado: Guaramiranga, 9.VIII.1993, M.R.L. Oliveira (EAC 23013).

68. Senegalia tenuifolia (L.) Britton \& Rose, N. Amer. Fl. 23(2): 118. 1928.

Espécie arbustiva semelhante a S. polyphylla, no entanto, se diferencia por apresentar folhas maiores (12 a 15 pares de pinas) e corola glabra. Espécie distribuída da América Central (México, Costa Rica e Panamá) até América do Sul (Peru e Brasil) e ainda no Caribe (Rico-Arce 2007). No semiárido brasileiro é encontrada principalmente em áreas de savana estépica, vegetação arbustiva caducifólia não espinhosa, floresta ombrófila densa atlântica e floresta estacional (Bocage 2005). Na Serra de Baturité foi encontrada em áreas de florestas estacionais e ombrófilas.

Material selecionado: Aratuba, 23.IX.2001, A.S.F. Castro 1077 (EAC); Baturité, 1.V.2001, fl., A.S.F. Castro 963 (EAC); Pacoti, 3.V.1998,A.S.F. Castro 573 (EAC).
Stryphnodendron Mart., Flora 20(2): Beibl. 117. 1837.

Gênero arbóreo ou arbustivo, inerme, caracterizado pelas folhas bipinadas com foliólulos alternos, inflorescência espiciforme, flores pentâmeras, diplostêmones, estames livres ou unidos próximo a base, anteras com glândulas caducas e frutos do tipo legume nucóide ou folículo. Stryphnodendron tem ampla distribuição no Neotrópico, sendo predominante na América do Sul, com cerca de 36 espécies, dos quais 18 são encontradas no Brasil, principalmente na floresta ombrófila densa amazônica, savana estépica, savana e floresta ombrófila densa atlântica (Scalon 2007). Na Serra de Baturité foi encontrada apenas uma espécie.

69. Stryphnodendron guianense (Aubl.) Benth., Trans. Linn. Soc. London 30(3): 374. 1875.

Fig. 6a-d

Espécie arbórea, facilmente reconhecida na Serra de Baturité pela combinação de folhas bipinadas com foliólulos alternos, nectários extraflorais nos pecíolos, flores em espigas e androceu com até 10 estames. Segundo Scalon (2007), S. guianense possui distribuição disjunta entre a Amazônia e o Nordeste (Ceará e Maranhão). $\mathrm{Na}$ Serra de Baturité foi encontrada apenas em áreas a barlavento acima de $600 \mathrm{~m}$.

Material examinado: Guaramiranga, 18.12.1988, A. Fernandes et al. (EAC 15701). Pacoti, 1.XI.1998, fl., L. W. Lima-Verde 2400 (EAC).

Vachellia Wight \& Arn., Prodr. Fl. Ind. Orient. 1: 272. 1834.

Gênero arbustivo facilmente reconhecido pela combinação de espinhos nodais, inflorescência glomeruliforme axilar e frutos indeiscentes. Vachellia tem distribuição pantropical com cerca de 160 espécies distribuídas nas Américas, África, Ásia, Austrália e ilhas do Pacífico associada à ambientes secos (Orchard \& Maslin 2003). Na Serra de Baturité foi encontrada apenas uma espécie.

70. Vachellia farnesiana (L.) Wight \& Arn., Prodr. Fl. Ind. Orient. 1: 272.1834. Fig. 6e-i

Espécie facilmente reconhecida pela combinação de espinhos nodais, inflorescência glomeruliforme axilar com flores amarelas e frutos indeiscentes. É uma espécie de ampla distribuição em áreas tropicais e subtropicais. No Brasil ocorre desde a Amazônia até a Região Sul, 


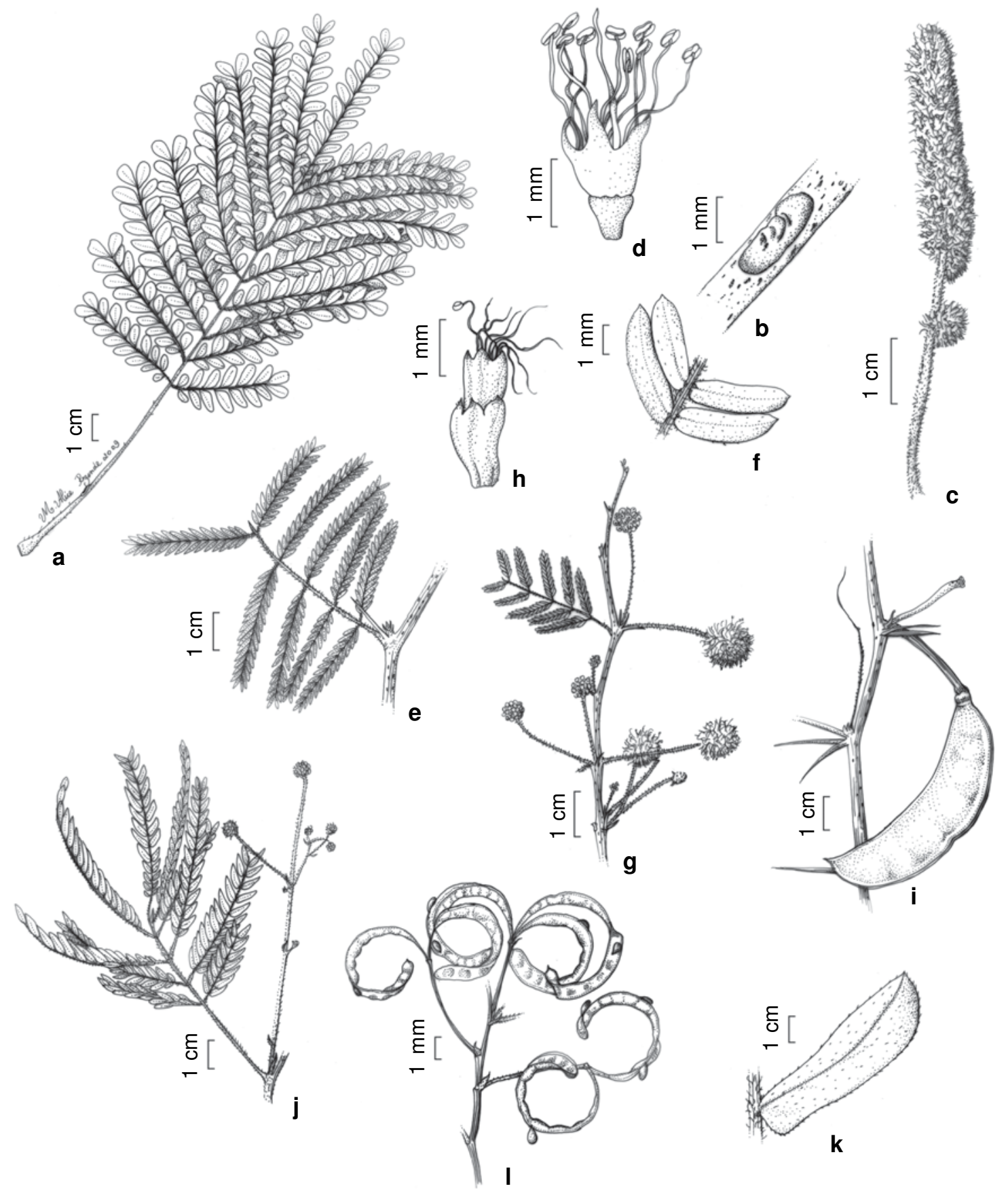

Figura 6 - a-d. Stryphnodendron guianense (Aubl.) Benth - a. folha; b. nectário extrafloral; c. inflorescência; d. flor (J.R. Lima 414). e-i. Vachellia farnesiana (L.) Wight \& Arn. - e. folha; f. folíolos; g. ramo com inflorescência; h. flor; i. fruto (J.I.A. Falcão et al. 1093). j-1.Zapoteca portoricensis Benth. - j. ramo com inflorescência; k. folíolo (E. Nunes \& P. Martins - RB 462057); 1. fruto (A. Fernandes \& Matos - RB 462060).

Figure 6 - a-d. Stryphnodendron guianense (Aubl.) Benth - a. leaf; b. extrafloral nectary; c. Inflorescence; d. flower. e-i. Vachellia farnesiana (L.) Wight \& Arn. - e. leaf; f. leaflets; g. branch with inflorescence; h. flower; i. fruit. j-1. Zapoteca portoricensis Benth. -j. branch with inflorescence; k. leaflet; 1. fruit. 
sendo encontrada em florestas estacionais e pastagens. No semiárido brasileiro é encontrada principalmente em áreas de savana estépica e floresta estacional (Bocage 2005). Na Serra de Baturité foi encontrada apenas em áreas a sotavento.

Material examinado: Pacoti, 20.IX.2007, J.R. Lima 200 (EAC, RB).

Material adicional: PARAIIBA: Santa Rita, 14.IX.1954, fr., J.I.A. Falcão et al. 1093 (RB).

Zapoteca H. M. Hern., Ann. Missouri Bot. Gard. 73(4): 757. 1986 [1987].

Arbustos inermes caracterizado pelos folíolos membranáceos, inflorescência glomeruliforme, homomórfica, flores pentâmeras, sésseis, políades com 16 grãos de pólen e fruto do tipo legume com valvas rompendo da base para o ápice. Gênero distribuído nas Américas com cerca de 17 espécies (Hernandéz 1989). Ocorre em florestas estacionais, em regiões áridas e semiáridas, e na floresta ombrófila densa amazônica.
71. Zapoteca portoricensis (Jacq.) H.M. Hern., Ann. Missouri Bot. Gard. 73(4): 758. 1986 [1987].

Fig. 6j-1

Zapoteca portoricensis pode ser confundida com as espécies de Calliandra por apresentarem frutos com deiscência elástica e as valvas arqueadas quando abertas. No entanto, $Z$. portoricensis tem folíolos membranáceos e inflorescência globosa enquanto as espécies de Calliandra possuem folíolos cartáceos e inflorescência não globosa. É uma espécie de ampla distribuição nas Américas. No Brasil é encontrada nos estados do Pará, Ceará, Pernambuco, Goiás e Mato Grosso (Hernandéz 1989). Na Serra de Baturité foi encontrada em áreas de floresta ombrófila.

Material examinado: Aratuba, 14.V.1980, fl., E. Nunes \& P. Martins (RB 462057). Guaramiranga, 2.VI.2004, fr., V. Gomes et al. 206 (EAC). Pacoti, 4.VI.1983, A. Fernandes et al. (EAC 12057).

Material adicional: PARAÍBA: Teixeira, 30.VI.1979, fr., A. Fernandes \& Matos (RB 462060).

\section{Chave de identificação dos gêneros de Papilionoideae da Serra de Baturité}

1. Árvores.

2. Folhas simples.

Zollernia

2. Folhas tri a multifolioladas.

3. Fruto legume ou folículo.

4. Folhas trifolioladas

Erythrina

4. Folhas com 5 ou mais folíolos.

5. Corola com 5 pétalas, papilonácea, estames concrescidos.

6. Hipanto ausente; ovário piloso Lonchocarpus

6'. Hipanto presente; ovário glabro Gliricidia

5'. Corola com uma pétala, não papilionácea; estames livres Trischidium

3'. Fruto sâmara.

7. Folhas opostas

7'. Folhas alternas.

Platymiscium

8. Estames livres.

9. Flores com 5 pétalas; folíolos com listras e pontos translúcidos .. Myroxylon

9'. Flores com 1 pétala; folíolos sem essas características.

10. Fruto com sementes distais

Amburana

10'. Fruto com sementes centrais Ateleia

8'. Estames concrescidos.

11. Sâmaras com sementes basais; estípulas espinescentes Machaerium

11'. Sâmaras com sementes centrais; estípulas não espinescente Dalbergia

1'. Outros hábitos.

12. Trepadeiras herbaceas e lenhosas.

13. Fruto lomento, folhas com 5 folíolos Chaetocalyx

13'. Fruto legume, folhas trifolioladas.

14. Flores ressupinadas. 
15. Fruto com uma ala estreita próximo à margem superior; flores em pseudoracemos nodosos; cálice 2-laciniado; pétalas róseas a lilases Canavalia

15'. Fruto não alado; flores isoladas, fasciculadas ou em inflorescências cimosas; cálice 5-laciniado; pétalas vermelhas Periandra

14'. Flores não ressupinadas.

16. Flores com pétalas amarelas.

17. Trepadeira lenhosa. Estandarte menor que as outras pétalas; anteras distintamente dimórficas; gineceu com mais de 5 óvulos

Mucuna

17'. Trepadeira herbacea. Estandarte maior que as outras pétalas; anteras uniformes; gineceu com 2 óvulos

Rhynchosia

16'. Flores com pétalas de outras cores.

18. Flores assimétricas.

19. Flores com alas quase do mesmo tamanho que o estandarte Vigna

19'. Flores com alas maiores que o estandarte Macroptilium

18'. Flores zigomorfas.

20. Trepadeiras herbáceas.

21. Cálice com lacínias lineares, pétalas azuladas Calopogonium

21'. Cálice com lacínias ovais a lanceoladas, pétalas lilases a roxas Galactia

20'. Trepadeiras lenhosas.

22. Estandarte glabro na face exterior

Dioclea

22'. Estandarte pubescente (pelo menos próximo ao ápice) na face exterior

Cratylia

12'. Ervas, arbustos e subarbustos.

23. Folhas com até 4 folíolos.

24. Folhas uni ou trifolioladas.

25. Fruto legume.

26. Folhas uni ou trifolioladas; flores amarelas, anteras dimórficas mais longas basifixas e mais curtas dorsifixas.

Crotalaria

26'. Folhas sempre trifolioladas; flores lilases a roxas, anteras uniformes . Centrosema

25'. Fruto lomento.

27. Flores amarelas Stylosanthes

27'. Flores róseas Desmodium

24'. Folhas com 2 ou 4 folíolos.

28. Folhas com 2 folíolos; flores em espigas; fruto lomento

Zornia

28'. Folhas com 4 folíolos; flores solitárias; fruto geocárpico, não se dividindo em segmentos monospérmicos Arachis

23'. Folhas com 5 ou mais folíolos.

29. Folhas imparipinadas; flores com corolas róseas a avermelhadas Indigofera

29'. Folhas paripinadas; flores com corolas amarelas.

30. Ervas ou subarbustos; fruto lomento

30'. Arbustos; fruto legume

Aeschynomene Sesbania

Aeschynomene L., Sp. Pl. 2: 713-714. 1753.

Gênero herbáceo, subarbustivo ou arbustivo caracterizado pelas folhas alternas (pinadas) e folíolos alternos ou opostos, sem pontuações translúcidas, inflorescência racemiforme com flores amarelas, androceu com dez estames (diadelfos) e fruto do tipo lomento.
Aeschynomene é um gênero pantropical com cerca de 180 espécies (Lewis et al. 2005). Destas, 84 são encontradas no Neotrópico, das quais cerca de 50 ocorrem no Brasil (Fernandes 1996). É um dos gêneros com maior número de espécies da subfamília na Serra de Baturité (seis espécies). 


\section{Chave de identificação das espécies de Aeschynomene da Serra de Baturité}

1. Estípulas peltadas.

2. Folíolos com duas ou mais nervuras basais divergentes; estípulas persistentes .... A. americana

2'. Folíolos com uma nervura principal; estípulas caducas.

3. Frutos e partes vegetativas enegrecidos ao secarem A. sensitiva

3'. Frutos e partes vegetativas castanhos, verdes ou amarelados ao secarem.

4. Estipe do fruto menor que $10 \mathrm{~mm}$ de comprimento.

5. Folhas com até $4 \mathrm{~cm}$ de comprimento, estípula até $10 \mathrm{~mm}$; estipe até $4 \mathrm{~mm}$

A. evenia

5'. Folhas maior que $4 \mathrm{~cm}$ de comprimento, estípula maior que $12 \mathrm{~mm}$; estipe maior que $4 \mathrm{~mm}$ A. rudis

4'. Estipe do fruto maior que $10 \mathrm{~mm}$ de comprimento A. scabra

1'. Estípulas não peltadas A. benthamii

72. Aeschynomene americana L., Sp. Pl. 2: 713714. 1753.

72.1 Aeschynomene americana $\mathrm{L}$. var. americana

Espécie subarbustiva, caracterizada pelos folíolos com duas ou mais nervuras basais divergentes e estípulas persistentes, o que a diferencia das outras espécies da Serra de Baturité. É encontrada na América Central e do Sul, tendo preferência por áreas úmidas, como por exemplo, alagados e baixios (Fernandes 1996). Na Serra de Baturité foi encontrada em áreas de floresta ombrófila. Material examinado : Baturité, 1939, fr., J.E. Leite 686 (RB).

\section{Aeschynomene benthamii (Rudd) A.} Fernandes Fig. 7a-b

Espécie subarbustiva caracterizada pelos ramos com tricomas glandulares, folíolos com uma nervura principal, estípulas não peltadas, caducas, lanceoladas; inflorescência racemiforme axilar e fruto com até três artículos. Espécie distribuída do Ceará à Bahia, sendo citada para o Rio de Janeiro (Fernandes 1996). É encontrada em borda de mata e áreas de savana estépica. Na Serra de Baturité é encontrada em áreas de florestas estacionais.

Material examinado: Baturité, 26.V.1996, A.S.F. Castro (EAC 24007).

Material adicional: BAHIA: Parque Nacional de Monte Pascoal, 12.I.1977, fl. e fr., R.M. Harley 17879 (RB).

74. Aeschynomene evenia $\mathrm{C}$. Wright ex Sauvalle, Anales Acad. Ci. Med. Habana 5: 334-335.

74.1 Aeschynomene evenia var. serrulata Rudd., Contr. U.S. Natl. Herb. 32(1): 61-62. 1955.

Subarbusto caracterizado pelos folíolos com uma nervura principal, frutos com margem reta e artículos aproximadamente quadrados. É semelhante à $A$. rudis, no entanto, se diferencia desta por apresentar folhas, estípulas e estipe menores. Espécie distribuída pelas Américas, sendo considerada invasora de áreas alteradas (Fernandes 1996). Na Serra de Baturité é encontrada em áreas de florestas estacionais.

Material examinado: Baturité, 10.VIII.1939, fr., J.E. Leite 641 (RB). Capistrano, 13.V.1980, fl., E. Nunes et al. (EAC 8565). Pacoti, 4.VI.1983, fl., A. Fernandes et al. (EAC 12056).

75. Aeschynomene rudis Benth., Pl. Hartw. 116. 1843.

Espécie subarbustiva semelhante à A. evenia por apresentarem frutos e partes vegetativas castanhos, verdes ou amareladas ao secarem e os artículos dos frutos aproximadamente quadrados, no entanto, diferencia desta por apresentar estipe menor e sem curvatura (Fernandes 1996). Distribuise desde a Argentina até os Estados Unidos e no Brasil é encontrada apenas nos estados do AM, PA e CE (Fernandes 1996). Na Serra de Baturité é encontrada em áreas de floresta estacionai.

Material examinado: Palmácia, 10.IV.1990, fl., A.S.F.Castro 546 (EAC).

76. Aeschynomene scabra G. Don, Gen. Hist. 2: 284. 1832.

Espécie subarbustiva diferenciada das outras espécies da série Indicae encontradas na Serra de Baturité por apresentar a estipe maior que $10 \mathrm{~mm}$. Espécie encontrada na América Central e do Sul, sendo registrada no Brasil no Ceará e em Pernambuco (Fernandes 1996).

Material examinado: Baturité, 30.V.1939, fr., J.E. Leite (RB 44738). 


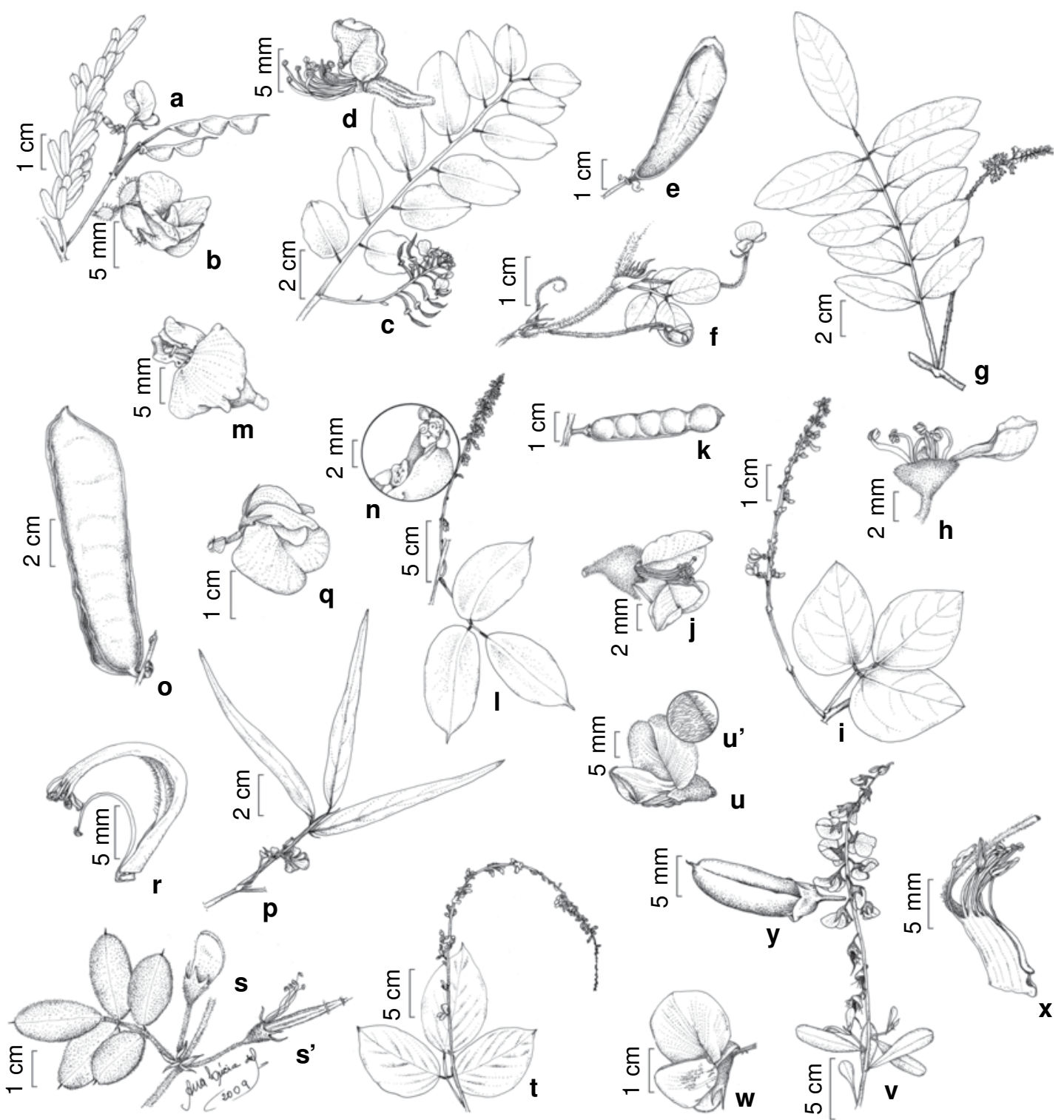

Figura 7 - a-b. Aeschynomene benthamii (Rudd) A. Fernandes-a. ramo com flor e frutos; b. flor (R.M. Harley 17879). c-e. Amburana cearensis (Allemão) A. C. Sm. - c. ramo com inflorescência; d. flor (N. L. Nunes 19 \& R.D. Ribeiro); e. fruto (B.A.S. Pereira \& D. Alvarenga 2870). f. Arachis pusilla Benth. - ramo com flor (A. Macêdo 598). g-h. Ateleia ovata Mohlembr. - g. ramo com inflorescência; h. flor (T. Guedes s.n. - RB 100407). i-k. Calopogonium caeruleum (Benth.) Britton - i. ramo com inflorescência (C.W. Fagg \& N. Oliveira); j. flor; k. fruto (J.R. Lima 201). 1-o.Canavalia parviflora Benth. - 1. ramo com inflorescência; $m$. flor; $n$. detalhe da nodosidade da inflorescência; o. fruto (L.C. Giordano et al. 1035). p-r. Centrosema pascuorum Mart. ex Benth. - p. ramo com flor; q. flor; r. detalhe do androceu e gineceu (J.R. Lima 513). s-s'. Chaetocalyx scandens (L.) Urb. - s. ramo com flor; s'. fruto (E. Córdula et al. 274). t-u'. Cratylia argentea (Desv.) Kuntze - t. ramo com inflorescência; u. Flor; u'. detalhe da flor (J.R. Lima 642). v-w. Crotalaria retusa L. - v. ramo com inflorescência; x. detalhe do androceu; y. fruto; w. flor (J.R. Lima 539).

Figure 7 - a-b. Aeschynomene benthamii (Rudd) A. Fernandes - a. branch with flower and fruits; b. flower. c-e. Amburana cearensis (Allemão) A.C. Sm. - c. branch with inflorescence d. flower; e. fruit. f. Arachis pusilla Benth. - flowering branch. g-h. Ateleia ovata Mohlembr. - g. branch with inflorescence; h. flower. i-k. Calopogonium caeruleum (Benth.) Britton - i. branch with inflorescence; j. flower; k. fruto. 1-o. Canavalia parviflora Benth. -1 . branch with inflorescence; $m$. flower; $n$. detail of the nodule of the inflorescence; o. fruit. p-r. Centrosema pascuorum Mart. ex Benth. - p. branch with flower; q. flower; r. details of the androecium and gynoecium. s-s'. Chaetocalyx scandens (L.) Urb. - s. flowering branch; s'. fruit t-u'. Cratylia argentea (Desv.) Kuntze - t. branch with inflorescence; u. flower; u'. detail of the flower. v-w. Crotalaria retusa L. - v. branch with inflorescence; x. details of the androecium; y. fruit; w. flower. 
77. Aeschynomene sensitiva Sw., Prodr. 107. 1788. 77.1 Aeschynomene sensitiva $\mathrm{Sw}$. var. sensitiva

A espécie varia de herbácea a subarbustiva facilmente reconhecida por apresentar folíolos com uma nervura principal, os frutos e as partes vegetativas enegrecidos ao secarem e ovário com margem glabra. É amplamente distribuída na América Central e do Sul (Fernandes 1996). Na Serra de Baturité foi encontrada em áreas de florestas estacionais e ombrófilas.

Material examinado: Aratuba, 14.VII.1980, fl., A. Fernandes et al. (EAC 8868). Baturité, VII.1937, fr., J.E. Leite 640 (RB). Mulungu, 12.XI.2007, J.R. Lima 342 (EAC, RB).

Amburana Schwacke \& Taub., Nat. Pflanzenfam. 3(3): 387. 1894.

Gênero arbóreo caracterizado pelas folhas imparipinadas e flores com apenas uma pétala. Amburana é um gênero da América do Sul representado por apenas três espécies (Lewis et al. 2005). É encontrado em florestas estacionais e savana estépica. Na Serra de Baturité foi encontrada apenas uma espécie.

78. Amburana cearensis (Allemao) A.C. Sm., Trop. Woods 62: 30. 1940.

Fig. 7c-e

Espécie arbórea reconhecida pela combinação de folhas imparipinadas, folíolos alternos, inflorescência paniculada, flores brancas com uma única pétala, estames livres e frutos do tipo sâmara com semente distal e ala proximal. A espécie é bem distribuída pelas florestas estacionais da América do Sul, sendo encontrada também em áreas de savana estépica (Prado \& Gibbs 1993). Na Serra de Baturité foi encontrada em áreas na vertente a sotavento.

Material examinado: Capistrano, 9.III.1994, J.B.L.P. Medeiros et al. (EAC 21564).

Material adicional: RIO DE JANEIRO: Rio de Janeiro, 4.V.2007, fl., N.L. Nunes 19 \& R.D. Ribeiro (RB 469962). TOCANTINS: Aurora do Tocantins, 16.VIII.1995, fr., B.A.S. Pereira \& D. Alvarenga 2870 (RB).

Arachis L., Sp. Pl. 2: 741.1753.

Gênero herbáceo com folhas pinadas, dois pares de folíolos, estípulas unidas ao pecíolo, flores solítárias amarelas, hipanto alongado e filiforme, androceu com dez estames (monadelfo) e fruto indeiscente e subterrâneo. Arachis é um gênero neotropical com 69 espécies (Lewis et al. 2005), comum em florestas estacionais tropicais e subtropicais e savana estépica. Na Serra de Baturité foi encontrada apenas uma espécie.
79. Arachis pusilla Benth., Trans. Linn. Soc. London 18(2): 159. 1841.

Fig. $7 f$

Erva anual facilmente reconhecida pela combinação de folhas tetrafolioladas, inflorescência em espiga curta, flores amarelas, estandarte com detalhes vermelhos, androceu com dez estames (monadelfo) e frutos geocárpicos com dois artículos. Distribui-se do Piauí até Minas Gerais, sendo considerada endêmica da Savana Estépica (Queiroz 2009). Na Serra de Baturité foi encontrada apenas na vertente a sotavento.

Material examinado: Baturité, 11.IV.1909, fl., A. Ducke (RB 12177).

Material adicional: MATO GROSSO: Fazendo do Poço, 30. XI.1944, fl., A. Macêdo 598 (RB).

Ateleia (DC.) Benth., Comm. Legum. Gen. 27, 37. 1837.

Gênero arbóreo ou arbustivo caracterizado pelas folhas compostas alternas, flores com apenas uma pétala e frutos do tipo sâmara. Ateleia é um gênero neotropical (México, América Central e do Sul), com cerca de 20 espécies, ocorrendo em florestas estacionais tropicais, subtropicais, arbustarias e savana estépica (Lewis et al. 2005). Na Serra de Baturité foi encontrada apenas uma espécie.

80. Ateleia ovata Mohlembr., Webbia 17(1): 176, f. 1,14. 1962.

Fig. 7g-h

Espécie arbórea reconhecida pela combinação de flores com uma única pétala, estames livres e sâmaras com sementes centrais. Ocorre principalmente em áreas de floresta ombrófila densa atlântica. Na Serra de Baturité foi encontrada em áreas de florestas estacionais e ombrófilas.

Material examinado: Pacoti, 14.VI.1957, fl., T. Guedes (IPA 8468, RB 100407).

Calopogonium Desv, Ann. Sci. Nat. (Paris) 9: 423. 1826.

Gênero com espécies trepadeiras, herbáceas ou arbustos escandentes facilmente reconhecido pela combinação de folhas trifolioladas, inflorescência pseudoracemosa e frutos do tipo legume septados internamente. Calopogonium é um gênero neotropical com cinco ou seis espécies (Lewis et al. 2005) encontradas em florestas estacionais tropicais e subtropicais, frequentemente próximos a rios ou pântanos, arbustarias e em áreas perturbadas. Na Serra de Baturité foi encontrada apenas uma espécie. 
81. Calopogonium caeruleum (Benth.) Sauvalle, Anales Acad. Ci. Med. Habana 5: 337. 1868 [1869].

Fig. 7i-k

Espécie trepadeira com folhas trifolioladas e flores com cálice piloso, pétalas azuladas e glabras. Esta espécie é aparentemente semelhante a G. striata, devido à cor das flores. Mas, distingue-se perfeitamente pelas características morfológicas da inflorescência e da flor. Espécie de distribuição neotropical. Na Serra de Baturité foi encontrada em áreas de florestas estacionais e ombrófilas.

Material examinado: Aratuba, 30.VIII.1979, fr., S.J. Filho 93 (IPA). Baturité, 1859, fl., F.F. Allemão (R 65155). Mulungu, 19.X.1979, A.S.J. Castro et al. (EAC 7158). Pacoti, 20.IX.2007, J.R. Lima 201 (EAC, RB).

Material adicional: GOIÁS: Monte Alegre, 16.IV.2003, fl., C.W. Fagg \& N. Oliveira (RB 477922).

Canavalia DC., Prodr. 2: 403-404. 1825.

Gênero com espécies de hábito trepador (herbáceo e lenhoso), folhas trifolioladas e flores ressupinadas com pétalas variando de róseas a lilases. Canavalia é um gênero pantropical com cerca de 60 espécies, das quais 33 ocorrem no Neotrópico. São encontradas em florestas inundáveis, florestas estacionais e savana estépica. Na Serra de Baturité foi encontrada apenas uma espécie.
82. Canavalia parviflora Benth., Fl. Bras. 15(1B): 177. 1862. Fig. 71-0

A espécie é facilmente reconhecida na Serra de Baturité pela combinação de hábito trepador, flores em pseudoracemos nodosos, flores com pétalas róseas a lilases, frutos com uma ala estreita próximo à margem superior e elasticamente deiscente. Ocorre no Peru e no Brasil, sendo encontrada em áreas de floresta ombrófila densa e florestas estacionais. Na Serra de Baturité foi encontrada em áreas de florestas ombrófilas.

Material examinado: Guaramiranga, 12.IX.1993, fl., M.R.L. Oliveira (EAC 22053).

Material adicional: RIO DE JANEIRO: Paraty, 11.IV.1991, fl., L.C. Giordano 1035 (RB).

Centrosema (DC.) Benth., Comm. Legum. Gen. 5354. 1837.

Trepadeiras lenhosas ou herbáceas caracterizadas pela inflorescência racemosa, axilar, flores ressupinadas, lilases a roxas, anteras uniformes e frutos do tipo legume com deiscência elástica. Centrosema é um gênero neotropical com cerca de 36 espécies (Lewis et al.2005) encontradas em formações arbustivas, florestas estacionais, floresta ombrófila densa atlântica, vegetação arbustiva caducifólia não espinhosa e savana florestada. Na Serra de Baturité foram encontradas cinco espécies.

\section{Chave de identificação das espécies de Centrosema da Serra de Baturité}

1. Folhas unifolioladas e sagitadas; pecíolo alado C. sargittatum

1'. Folhas trifolioladas e não sagitadas; pecíolo não alado.

2. Plantas enegrecidas ou marrom-escuras quando herborizadas; pecíolo maior que $5 \mathrm{~cm}$ de comprimento; folíolos terminais \pm rombóides . C. plumieri

2'. Plantas verdes quando herborizadas; pecíolo menor que $3,5 \mathrm{~cm}$ de comprimento; folíolos terminais nunca rombóides.

3. Folíolos linear-lanceolados

C. pascuorum

3'. Folíolos ovados a lanceolados.

4. Lacínias do cálice de comprimentos semelhantes

C. virginianum

4'. Lacínias do cálice de comprimentos desiguais

C. brasilianum

83. Centrosema brasilianum (L) Benth., Comm. Legum. Gen. 54. 1837

Espécie herbácea semelhante à $C$. pascuorum e $C$. virginianum por apresentarem coloração verde quando herborizadas. No entanto, diferencia-se de C. virginianum por apresentar lacínias do cálice de comprimentos desiguais e de C. pascuorum por apresentar os folíolos ovados-lanceolados. Espécie neotropical considerada invasora, sendo comum em locais antropizados (Williams \& Clements 1990). Na Serra de Baturité é encontrada em áreas de floresta estacional.

Material examinado: Baturité, 1937, fl., J.E. Leite 669 (RB). Capistrano, 14.VII.1994, J.B.L.P. Medeiros et al. 125 (EAC). 
84. Centrosema pascuorum Mart. ex Benth., Comm. Legum. Gen. 56. 1837. Fig. $7 \mathrm{p}-\mathrm{r}$

Espécie trepadeira herbácea reconhecida vegetativamente pelas folhas trifolioladas com folíolos estreitos, linear-lanceolados (aproximadamente 10 vezes mais longos do que largos). Segundo Williams \& Clements (1990), a espécie é neotropical, sendo encontrada na América Central (Costa Rica, México e Panamá) e América do Sul (Bolívia, Brasil e Equador). Na Serra de Baturité é encontrada tanto em áreas de florestas estacionais quanto ombrófilas.

Material examinado: Guaramiranga, 18.IV.2008, fl., J.R. Lima 513 (EAC, RB). Palmácia, 20.IV.1998, A.S F. Castro (EAC 26556).

85. Centrosema plumieri (Turpin ex Pers.) Benth., Comm. Legum. Gen. 54. 1837.

Espécie trepadeira facilmente reconhecida por apresentar coloração enegrecida ou marrom-escura quando herborizada, inflorescência axilar e flores com pétalas brancas com parte central roxa. Espécie neotropical, introduzida na África tropical (Fantz 2001). Na Serra de Baturité é encontrada em áreas de floresta ombrófila.

Material examinado: Baturité, 1860, fl., F.F. Allemão \& M. Cisneiros 377 (R). Pacoti, 30.VII.1941, P. Bezerra 305 (EAC).

86. Centrosema sagittatum (Willd.) L. Riley, Bull. Misc. Inform. Kew 1923(9): 344. 1923.

Espécie trepadeira facilmente vegetativamente por apresentar folhas unifolioladas, em forma de seta e pecíolo alado, além das pétalas obovais e bicolores. Distribui-se pelas vegetações secundárias da América do Sul (Fantz 2001). Na Serra de Baturité é encontrada em áreas de florestas estacionais.

Material examinado: Aratuba, 14.V.1980, P. Martins et al. (EAC 8604). Capistrano, Serra do Vicente, 13.V.1980, E. Nunes et al. (EAC 8567).

87. Centrosema virginianum (L.) Benth., Comm. Legum. Gen.: 56. 1837.

Espécie trepadeira semelhante à $C$. brasilianum, porém as lacínias do cálice em $C$. virginianum são de comprimentos semelhantes, enquanto que em $C$. brasilianum as lacínias são de comprimentos desiguais. Espécie amplamente distribuída no Neotrópico (Williams \& Clements 1990). Na Serra de Baturité é encontrada em áreas de floresta ombrófila.

Material examinado: Baturité, 16.VI,1989, fl., M.A. Figueiredo et al. (EAC 16716).
Chaetocalyx DC., Prodr. 2: 243. 1825.

Gênero com espécies trepadeiras, caracterizado pelas folhas imparipinadas, inflorescência racemosa, flores com pétalas amarelas, as alas e carena aproximadamente do mesmo tamanho e fruto do tipo lomento. Chaetocalyx é um gênero neotropical com 13 espécies (Rudd 1958; 1972). Ocorrem em florestas estacionais e florestas temperadas, arbustarias e savana estépica. Na Serra de Baturité foi encontrada apenas uma espécie.

88. Chaetocalyx scandens var. pubescens (DC.) Rudd, U.S. Nat. Herb. 32: 236. $1958 . \quad$ Fig. 7. s-s'

Espécie trepadeira reconhecida pelas folhas imparipinadas com cinco folíolos, pecíolo pubescente, inflorescência racemosa, cálice formando um tubo, cinco lacínias lanceoladas do mesmo tamanho, pétalas amarelas e fruto do tipo lomento. Distribuída na América do Sul, Bolívia, Venezuela e Brasil, principalmente em áreas de savana estépica (Queiroz 2006b). Na $\mathrm{Na}$ Serra de Baturité é encontrada em áreas de floresta ombrófila.

Material examinado: Guaramiranga, 17.V.1959, fl., A. Fernandes (EAC 1876).

Material adicional: PERNAMBUCO: Mirandiba, 14.VI.2007, fl. e fr., E. Córdula et al. 274 (HUEFS, RB).

Cratylia Mart. ex Benth., Comm. Legum. Gen. 67. 1837. Gênero arbustivo ou trepadeiras lenhosas caracterizado pelas folhas trifolioladas, inflorescência pseudoracemosa nodosa, flores com pétalas variando de lilases a roxas e fruto do tipo legume. Cratylia é um gênero neotropical presente no Brasil, Bolívia, Peru e Norte da Argentina com cerca de sete espécies (Queiroz 2006b). Encontrado em áreas de florestas estacionais e ombrófilas e na savana estépica. Na Serra de Baturité foi encontrada apenas uma espécie.

89. Cratylia argentea (Desv.) Kuntze, Revis. Gen. Pl. 3 (3): 58. $1898 . \quad$ Fig. 7t-u'

Espécie lianescente facilmente reconhecida pela presença de um indumento argênteo na face abaxial dos folíolos. C. argentea tem ampla distribuição na América do Sul em florestas estacionais, savanas e floresta ombrófila densa amazônica, sendo encontrada ainda na savana estépica (Queiroz \& Coradin 1996). Na Serra de Baturité é encontrada tanto em áreas de floresta ombrófila quanto estacional. 
Material examinado: Baturité, 14.X.1957, fl., A. Fernandes (EAC 2592). Capistrano, 14.V.1980, fl., E. Nunes et al. (EAC 8583). Guaramiranga, 20.IX.2007, fl., J.R. Lima 193 (EAC, RB). Pacoti, 30.VI.1941, P. Bezerra 303(EAC). Palmácia, 8.X.1980, fl., E. Nunes et al. (EAC 8932).

Crotalaria L., Sp. Pl. 2: 714-716. 1753.

Gênero arbustivo ou subarbustivo caracterizado pelas folhas com um ou três folíolos, inflorescência racemosa, flores com pétalas amarelas, androceu com dez estames monadelfos, anteras dimórficas e fruto do tipo legume (inflado). Crotalaria é um gênero pantropical com cerca de 690 espécies, dais quais 35 ocorrem na América do Sul (Lewis et al.2005). Ocorrem em florestas estacionais tropicais e subtropicais, savana estépica e em áreas perturbadas. Na Serra de Baturité foram encontradas três espécies.

\section{Chave de identificação das espécies de Crotalaria da Serra de Baturité}

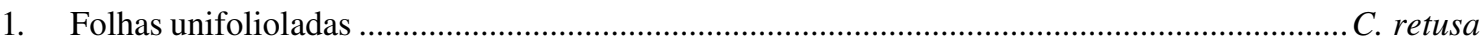

1'. Folhas trifolioladas.

2. Folíolos obovais a suborbiculares, mais curtos do que o pecíolo; racemos laxos ........... incana

2'. Folíolos elípticos, mais longos do que o pecíolo; racemos congestos ......................... C. pallida

90. Crotalaria incana L., Sp. Pl. 2: 716. 1753.

Espécie subarbustiva ou arbustiva diagnosticada pelas folhas trifolioladas, folíolos mais curtos que os pecíolos e inflorescência racemosa. Espécie pantropical, considerada invasora. Na Serra de Baturité é encontrada em áreas de floresta estacional.

Material examinado: Capistrano, 23.VII.1995, fl., A.S.F. Castro (EAC 23131).

91. Crotalaria pallida Blanco, Fl. Filip. 1:570. 1837. Espécie subarbustiva semelhante a $C$. incana por apresentar folhas trifolioladas, no entanto se diferencia desta pelos folíolos maiores e mais longos que o pecíolo. $C$. pallida é uma espécie pantropical, considerada invasora (Polhill 1982). Na Serra de Baturité é encontrada em áreas de floresta estacional.

Material examinado: Mulungu, 11.VII.2008, fr., J.R. Lima 665 (RB).

\section{Crotalaria retusa L., Sp. Pl. 2: 715. 1753.}

Fig. 7v-w

Espécie subarbustiva facilmente reconhecida pelas folhas unifolioladas. Provavelmente nativa da Ásia e introduzida no resto do mundo (Polhill 1982). Na Serra de Baturité é encontrada em áreas de floresta estacional.

Material examinado: Baturité, 14.XI.1990, fl., A. Fernandes et al. (EAC 17045). Mulungu, 31.X.2007, fl., J.R. Lima 308 (EAC, RB). Pacoti, 21.VI.2004, W.M. Bezerra (EAC 34302). Palmácia, 8.X.1980, fl.,P. Martins et al. (EAC 8933).
Dalbergia L. f., Suppl. Pl. 52, 316. 1781 [1782].

Gênero arbóreo, arbustivo ou escandente caracterizado pelas folhas alternas com cinco a sete folíolos, inflorescência do tipo cimeira, flores pequenas, pétalas de brancas a creme, androceu com nove estames (monadelfos) e frutos do tipo sâmara. Dalbergia é um gênero pantropical com cerca de 250 espécies, 38 ocorrendo no Brasil (Carvalho 1997). É encontrado em florestas ombrófilas, florestas estacionais tropicais e subtropicais e em áreas de savana estépica (Lewis et al. 2005). Na Serra de Baturité foi encontrada apenas uma espécie.

93. Dalbergia cearensis Ducke, Arch. Jard. Bot. Rio de Janeiro 4: 73. 1925.

Fig. 8a-d

Espécie arbórea reconhecida pela combinação de folhas e folíolos alternos, flores muito pequenas $(<5 \mathrm{~mm})$ reunidas em uma cimeira congesta, pétalas creme e sâmaras com sementes centrais. Dalbergia cearensis é considerada endêmica da savana estépica do Piauí até a Bahia (Carvalho 1997). Na Serra de Baturité é encontrada em áreas de floresta estacional.

Material examinado: Baturité, 10.IV.1909, fr., A. Ducke (RB 11587, MG 1952). Capistrano, 3.VIII.1993, J.B.L.P. Medeiros et al (EAC 21713). Pacoti, 15.XI.2007, J.R. Lima 412 (EAC, RB).

Material adicional: BAHIA: Tanque Novo, fr., 14.III.1981, S.B. Silva 208(RB). Pernambuco, 16.I.2001, fl., L.M. Nascimento 481 et al. (RB, PEUFR).

Desmodium Desv., J. Bot. Agric. 1: 122, pl.5,f. 15. 1813. Gênero subarbustivo, arbustivo ou herbáceo caracterizado pelas folhas imparipinadas (um ou três folíolos), inflorescência do tipo racemosa 


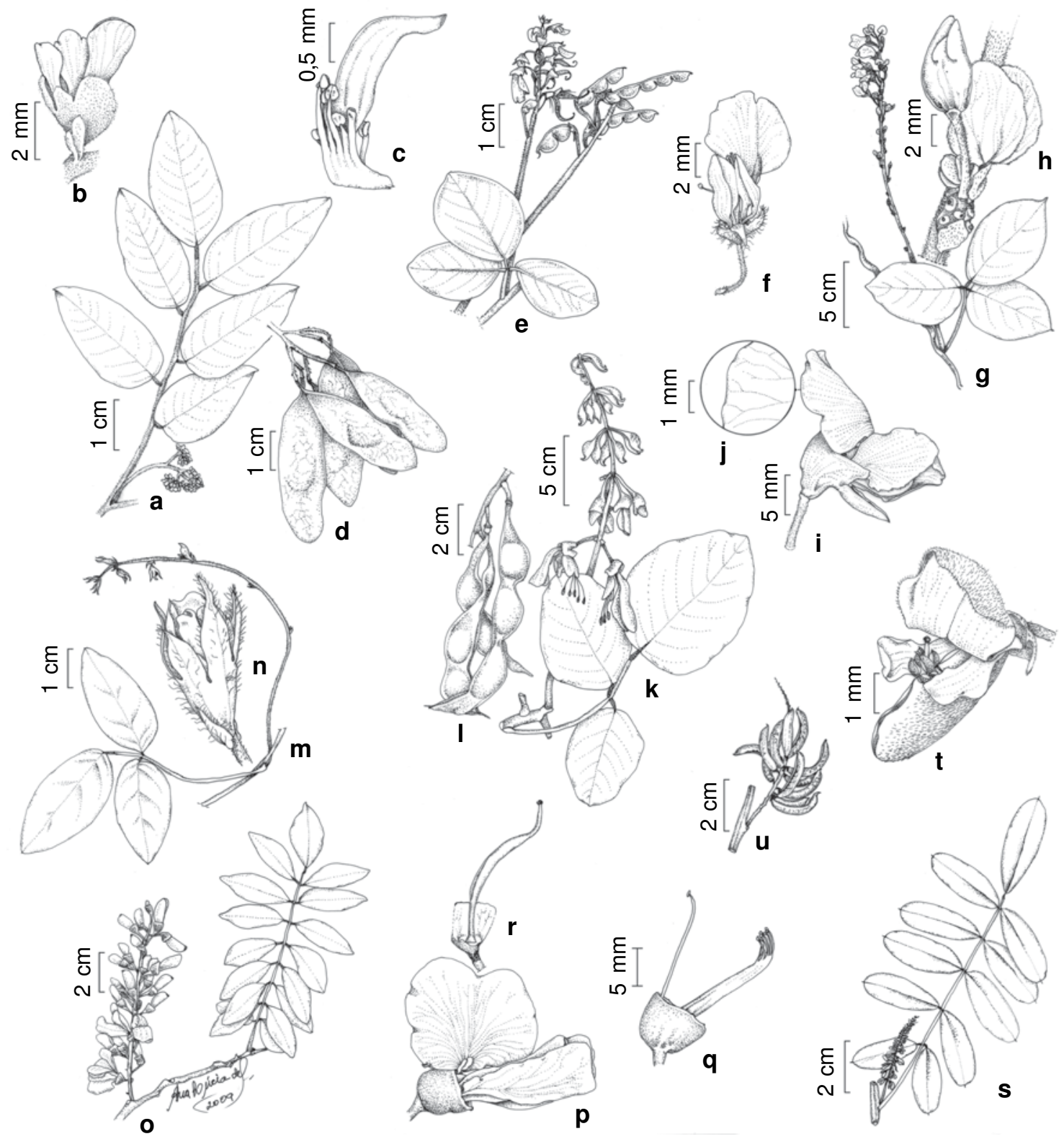

Figura 8 - a-d. Dalbergia cearensis Ducke - a. ramo com inflorescência; b. flor; c. detalhe da flor (L.M. Nascimento 481 et al. ); d. frutos (S.B. Silva 208). e-f. Desmodium incanum DC. - e. ramo com inflorescência e fruto; f. flor (J.R. Lima 541 ). g-j. Dioclea virgata (Rich.) Amshoff - g. ramo com inflorescência; $h$. nodosidade da inflorescência; i. flor; j. detalhe da flor (J.R. Lima 278). k-1. Erytrhina velutina Willd. - k. ramo com inflorescência (J.R. Lima 683); 1. frutos (L.A. Mattos Silva 2337 et al.). m-n Galactia striata (Jacq.) Urb. - m. ramo com inflorescência; n. flor (R.H.P. Andreata 366). o-r. Gliricidia sepium (Jacq.) Kunth ex Walp. - o. ramo com inflorescência;p. flor; q. detalhe da flor; r. gineceu (R.D. Ribeiro 324 et al.). s-u. Indigofera suffruticosa Mill. - s. ramo com inflorescência; t. flor; u. frutos (J.R. Lima 209). Figure 8 - a-d. Dalbergia cearensis Ducke - a. branch with inflorescence; b. flower; c. detail of the flower; d. fruits. e-f. Desmodium incanum DC. - e. branch with inflorescence and fruit; f. flower. g-j. Dioclea virgata (Rich.) Amshoff - g. branch with inflorescence; h. nodule of the inflorescence; i. flower; $\mathrm{j}$. detail of the flower. k-1. Erytrhina velutina Willd. - k. branch with inflorescence; 1 . fruits. m-n. Galactia striata (Jacq.) Urb. - m. branch with inflorescence; n. flower. o-r. Gliricidia sepium (Jacq.) Kunth ex Walp. - o. branch with inflorescence; p. flower; q. detail of flower; r. gynoecium. s-u. Indigofera suffruticosa Mill. - s. branch with inflorescence; t. flower; u. fruits. 
ou pseudoracemosa, flores com pétalas de róseas a roxas, androceu com dez estames (monadelfos) e fruto do tipo lomento. Desmodium é um gênero pantropical com cerca de 275 espécies (Lewis et al. 2005). Para o Brasil são citadas 40 espécies, sendo considerado um dos centros de diversidade da América do Sul (Azevedo 1981). É encontrado em florestas estacionais e ombrófilas, florestas temperadas, arbustarias, savana estépica e locais alterados. é o gênero com maior riqueza de espécies (sete) da subfamília Papilionoideae na Serra de Baturité.

\section{Chave de identificação das espécies de Desmodium da Serra de Baturité}

1. Lomento com sutura superior reta ou pouco sinuosa, ístmo marginal ou excêntrico.

2. Racemos curtos e densos, ca. $20-30 \mathrm{~mm}$ D. barbatum

2'. Racemos mais longos e laxos ou panícula pouco ramosa.

3. Inflorescência composta por um a dois racemos terminais.

4. Estípulas livres entre si; pétalas brancas D. affine

4'. Estípulas unidas entre si, ao menos quando jovem; pétalas róseas a roxas ... D. incanum 3'. Inflorescência paniculada terminal ou axilar.

5. Inflorescência com flores apenas a partir da metade superior; lomento com artículo reniforme D. axillare

5'. Inflorescência com flores desde a base; lomento com artículos não reniformes

D. uncinatum

1'. Lomento com ambas as suturas sinuosas, istmo central ou subcentral.

6. Artículos do lomento retos

D. distortum

6'. Artículos do lomento tortuosos D. glabrum

94. Desmodium affine Schlecht., Linnaea 12: 312313. 1838.

Espécie herbácea semelhante à $D$. incanum, porém diferencia desta por apresentar flores com pétalas brancas (róseas a roxas em D. incanum) e estípulas livres (unidas em $D$. incanum). D. affineé distribuída desde o México até a Argentina (Vanni 2001). No Brasil é encontrada no MA, CE, BA, MG, RJ, SP, PR, SC e RS, principalmente em áreas de floresta ombrófila, savana, campo, campo rupestre e pastagem (Azevedo 1981). Na Serra de Baturité é encontrada em áreas de florestas estacionais.

Material examinado: Baturité, fl. e fr.,J.E. Leite 645 (RB).

95. Desmodium axillare (Sw.) DC., Prodr. 2: 333. 1825.

Espécie herbácea (prostrada) caracterizada pelas folhas com pecíolo longo, estípulas soldadas, inflorescência racemosa axilar, sem flores na parte basal, flores com corola geralmente rósea e lomento geralmente com dois artículos. É semelhante à $D$. affine, mas diferencia-se por apresentar inflorescência axilar e não terminal. Distribuída no Peru, Colômbia, Guiana, Américas Central e do Sul (Bentham 1859-1862). No Brasil é encontrada nos estados de RR, AM, AP, PA, MT, MS, MA, CE, BA, ES, RJ e SP, ocorrendo em matas e bordas de matas, capoeira e pastagens (Azevedo 1981). Na Serra de Baturité é encontrada em áreas de floresta ombrófila. Material examinado: Guaramiranga, 12.II.1981, fl., A. Fernandes et al. (EAC 16335). Pacoti, 10.X.2007, fl., J.R. Lima 280 (EAC, RB).

96. Desmodium barbatum (L.) Benth., Pl. Jungh. 2: 224. 1852.

Espécie herbácea ou subarbustiva reconhecida por apresentar estípulas livres entre si, racemos terminais, curtos e densos, pétalas róseas, lilases ou azuladas e lomento com sutura superior reta ou pouco sinuosa, não estipitado, enegrecido quando seco. Espécie da América tropical e subtropical, sendo encontrada em áreas de Savana, campos, campinas, restinga, pantanal e floresta atlântica (Azevedo 1981). Possui características de plantas invasoras e pioneiras sendo frequentes em áreas cultivadas ou abandonadas (Azevedo 1981). Na Serra de Baturité é encontrada em áreas de floresta ombrófila.

Material examinado: Baturité, 9.XI.1937, fl. e fr., J.E. Leite 648 (RB). Guaramiranga, 20.VII.1991, E. Nunes (EAC 17857). 
97. Desmodium distortum (Aubl.) J.F. Macbr., Publ. Field Columbian Mus., Bot. Ser. 8(2): 101. 1930.

Espécie arbustiva ou subarbustiva caracterizada pelas folhas trifolioladas (inferiores menores e mais largas que as superiores), estípulas triangulares livres com base auriculada quase envolvendo o caule, inflorescência paniculada, laxa e lomento com ambas as suturas sinuosas e artículos retos. É encontrada no México, Guatemala e Peru. No Brasil é encontrada nos estados de AL, AM, BA, CE, DF, GO, MA, MT, MS, MG, PA, PB, PE, PI, RJ e SP, principalmente em áreas de savana, florestas, campos e beira de estrada (Azevedo 1981). Na Serra de Baturité é encontrada em áreas de floresta estacional.

Material examinado: Baturité, 23.V.1940, fl. e fr., D.R. Silva s.n. (RB 42375, UEC 8157).

98. Desmodium glabrum (Mill.) DC., Prodr. 2: 338. 1825.

Espécie herbácea ou subarbustiva com inflorescência racemosa, flores com pétalas vermelhas, facilmente reconhecida pelo fruto com $\mathrm{o}$ artículo distal muito maior do que os outros. Espécie neotropical. No Brasil ocorre na região Nordeste e nos estados do MT, MG e RJ (Azevedo 1981). Na Serra de Baturité é encontrada tanto em áreas de floresta ombrófila como de floresta estacional.

Material examinado: Baturité, 29.VII.1938, fl. e fr., J.E. Leite 2955 (RB). Palmácia, 20.IV.1998, A.S.F. Castro 555 (EAC).

99. Desmodium incanum DC., Prodr. 2: 332. 1825.

Fig. 8e-f

Espécie herbácea ou subarbustiva caracterizada pelas estípulas unidas na base, inflorescência pseudoracemosa, flores com pétalas de róseas a roxas e frutos com margem superior reta e inferior sinuosa. $D$. incanum é semelhante a $D$. affine, porém diferenciase dela por apresentar estípulas unidas e flores com pétalas de rosa a roxa. É distribuída por todo Brasil em áreas de savana, restinga, dunas, beira de estrada, pastageme áreas cultivadas (Azevedo 1981). Na Serra de Baturité é encontrada em áreas de florestas estacional e ombrófila.

Material examinado: Guaramiranga, 14.XI.1990, A. Fernandes et al. (EAC 17038). Mulungu, 31.X.2007, fl., J.R. Lima 307 (EAC, RB).

100. Desmodium uncinatum (Jacq.) DC., Prodr. 2: 331. 1825.

Espécie herbácea com folhas trifolioladas, estípulas livres, lanceoladas e lomento com cerca de seis artículos. É semelhante a D. axillare, mas diferencia se desta por apresentar inflorescência florífera a partir da base e lomento com artículo triangulares. Ocorre desde a América Central até a Argentina (Vanni 2001). No Brasil é encontrada no CE, BA, MG, RJ, SP, PR, SC e RS. D. uncinatum é considerada invasora e ruderal, ocorrendo em áreas de savana, campo rupestre, matas, pastagens (Azevedo 1981). Na Serra de Baturité é encontrada em áreas de florestas estacional e ombrófila.

Material examinado: Baturité, 12.VI.1976, A. Fernandes (EAC 2787). Capistrano, 13.V.1980, fl., $P$. Martins et al. (EAC 8566). Guaramiranga, 29.VII.1941, P. Bezerra et al. 277 (EAC). Pacoti, Serrinha, 4.VI.1983, A. Fernandes et al. (EAC 12028).

Dioclea Kunth, Nov. Gen. Sp. (quarto ed.) 6: 437. 1823 [1824].

Gênero lianescente caracterizado pelas folhas trifolioladas, inflorescências racemosas ou pseudoracemosas nodosas, axilares, eretas, pétalas lilases ou roxas com estandarte glabro na face exterior e fruto do tipo legume. Gênero pantropical com cerca de 40 espécies, 35 ocorrendo na América do Sul, principalmente no Brasil, com poucas espécies na África e no sudeste da Ásia (Lewis et al. 2005). Encontrado em florestas pluviais de terras baixas, florestas estacionais tropicais e subtropicais e savana estépica. Na Serra de Baturité foram encontradas quatro espécies.

\section{Chave de identificação das espécies de Dioclea da Serra de Baturité}

1. Estípulas caducas; carena curva para cima; semente circular com hilo envolvendo $2 / 3$ da circunferência.

2. Brácteas caducas.

3. Folíolos grabros; fruto glabro; semente escura, quase negra ....................... D. sclerocarpa

3'. Folíolo velutino na face abaxial; fruto piloso canescente; semente castanha a avermelhada

2'. Brácteas persistentes D. grandiflora D. megacarpa

1'. Estípulas persistentes; carena reta; semente oblonga com hilo envolvendo cerca de $1 / 2$ da circunferência D. virgata 
101. Dioclea grandiflora Mart. ex Benth., Comm. Legum. Gen. 68-69. 1837.

Espécie reconhecida pela combinação de inflorescência pseudoracemosa, flores com pétalas roxas, androceu com anteras dimórficas, frutos pilosos canescentes e sementes castanhas a avermelhadas. Endêmica da Savana Estépica sendo encontrada em todo semiárido brasileiro (Queiroz 2006b). Na Serra de Baturité é encontrada em áreas de floresta estacional.

Material examinado: Capistrano, 27.IV.1994, fl., J.B.L.P. Medeiros et al. (EAC 21565).

102. Dioclea megacarpa Rolfe, Bull. Misc. Inform. Kew 1901: 139. 1901.

Espécie com inflorescência racemosa, flores roxas com grandes brácteas persistentes. É distinta das outras espécies de Dioclea da Serra de Baturité por apresentar estípulas caducas e brácteas persistentes. Na Serra de Baturité é encontrada em áreas de floresta estacional.

Material examinado: Baturité, Sítio B. Inácio de Azevedo, 1937, J.E. Leite 627 (RB).

103. Dioclea sclerocarpa Ducke, Arch. Jard. Bot. Rio de Janeiro 3: 169-170. 1922.

Espécie com folíolos glabros, inflorescência racemosa, flores roxas e fruto glabro. É semelhante à $D$. grandiflora, mas se diferencia desta por apresentar fruto glabro e semente quase negra $(D$. grandiflora possui fruto piloso e semente castanha a avermelhada). Na Serra de Baturité é encontrada em áreas de florestas estacional e ombrófila.

Material examinado: Capistrano, 13.V.1980, fl., $P$. Martins et al. (EAC 8572). Pacoti, 4.VI.1983, A. Fernandes et al. (EAC 12030).

104. Dioclea virgata (Rich.) Amshoff, Meded. Bot. Mus. Herb. Rijks Univ. Utrecht 52: 69. 1939.

Fig. 8g-j

Espécie facilmente reconhecida pelos folíolos com ápice acuminado, pubescentes na face abaxial, estípulas persistentes, inflorescência racemosa, flores com pétalas vermelhas a arroxeadas e frutos com tricomas ferrugíneos. D. virgataé uma espécie neotropical. Na Serra de Baturité é encontrada em áreas de florestas estacionais e ombrófilas.

Material examinado: Aratuba, 18.X.1979, fl., A.J. Castro et al. (EAC 7130). Guaramiranga, 5.X.1990, fl., F.S. Cavalcanti et al. (EAC 16949). Mulungu, 22.IX.2001, fl., A.S.F. Castro 1070 (EAC). Pacoti, 10.X.2007, fl. e fr., J.R. Lima 278 (EAC, RB).
Erythrina L., Sp. Pl. 2: 706-707. 1753.

Gênero arbóreo ou arbustivo caracterizado pelas folhas trifolioladas, folhas vermelhas a vermelho-alaranjadas e sementes vermelhas. Erythrina é um gênero pantropical com cerca de 120 espécies, das quais 70 ocorrem no Neotrópico, sendo 20 na América do Sul. É encontrado em áreas de florestas estacionais tropicais, arbustarias e savana estépica (Lewis et al.2005). Na Serra de Baturité foram encontradas três espécies (E. crista-galli L., E. fusca Lour e $E$. velutina Willd), no entanto apenas a ultima é nativa e tratada no presente estudo.

105. Erythrina velutina Willd., Ges. Naturf. Freunde Berlin Neue Schriften 3: 426. 1801.

Fig. 8k-1

Espécie arbórea facilmente reconhecida por apresentar hábito arbóreo, tronco aculeado, folhas trifolioladas, inflorescência pseudoracemosa, flores com pétalas vermelho-alaranjadas, alas e carenas menores que o estandarte, androceu com dez estames (diadelfo) e fruto de tipo legume com sementes vermelhas. E. velutina é comum em áreas secas da América do Sul, sendo encontrada na Savana Estépica do Ceará até Minas Gerais e em brejos de altitudes (Queiroz 2006b). Na Serra de Baturité é encontrada em áreas de floresta ombrófila.

Material examinado: Guaramiranga, 21.IX.2007, J.R. Lima 236 (EAC, RB). Pacoti, 18.IV.2003, G.S.B. Viana (EAC 32431).

Material adicional: BAHIA: Poções, 5.IV.1988, fr., L.A. Mattos Silva et al. 2337 (RB).

Galactia P. Browne, Civ. Nat. Hist. Jamaica 298. 1756.

Gênero herbáceo, subarbustivo ou trepador caracterizado pelas folhas trifolioladas, inflorescência pseudoracemosa, flores com pétalas lilases, androceu diadelfo, anteras uniformes e fruto do tipo legume. Galactia é um gênero pantropical com cerca de 60 espécies, sendo que 30 delas são nativas da América doSul (Lewis et al.2005). ocorre em florestas estacionais tropicais, subtropicais e em áreas de savana estépica. NaSerra de Baturité foi encontrada apenas uma espécie.

106. Galactia striata (Jacq.) Urb., Symb. Antill. 2 (2): 320.1900.

Fig. $8 \mathrm{~m}-\mathrm{n}$

Espécie trepadeira caracterizada pelas estípulas triangulares, inflorescência pseudoracemosa, flores com cálice pubescente, corola glabra, pétalas lilases a roxas, androceu diadelfo e fruto do tipo legume. Espécie semelhante à Calopogonium caeruleum, no entanto esta espécie apresenta pétalas azuis. Amplamente distribuída na América do Sul desde 
o sudeste dos Estados Unidos até a Argentina (Burkart 1971). Na Serra de Baturité foi encontrada em áreas a sotavento.

Material examinado: Baturité, 07.V.1959, fl., A. Fernandes (EAC 1874). Capistrano, 25.VI.1994, J.B.L.P. Medeiros et al. (EAC 21563).

Material adicional: RIO DE JANEIRO: Itaipuaçú, 14.I.1982, fl. e fr., R.H.P. Andreata 366 (RB).

Gliricidia Kunth, Nov. Gen. Sp.(folio ed.) 6: 309. 1824.

Gênero arbóreo com folhas alternas, imparipinadas; inflorescências do tipo racemos; flores com pétalas lilases e estandarte com a porção central creme. $\mathrm{O}$ gênero possui cinco espécies que são encontradas na América Central e do Sul (Lewis et al. 2005). Na serra de Baturité foi encontrada apenas uma espécie.

107. Gliricidia sepium (Jacq.) Kunth ex Walp. Fig. 8o-r

Espécie arbórea ou arbustiva que compartilha com Lonchocarpus as folhas com 5 ou mais folíolos, flores papilionáceas (5 pétalas) e estames concrescidos, no entanto diferencia-se deste por apresentar hipanto e ovário glabro (enquanto em Lonchocarpus o hipanto é ausente e o ovário é piloso). É uma espécie amplamente introduzida em áreas tropicais, inclusive na Serra de Baturité. É encontrada em florestas estacionais e savana estépica (Lewis $e t$ al. 2005). Na Serra de Baturité é encontrada em áreas de florestas ombrófilas.

Material examinado: Mulungu, 9.IX.1990, fl., F.S. Cavalcanti \& S. Simões (EAC 16995).

Material adicional: RIO DE JANEIRO: Búzios, 29.VIII.2004, fl. e fr., R.D. Ribeiro 324 (RB).

Indigofera L., Sp. Pl. 2: 751. 1753.

Gênero arbustivo, subarbustivo ou herbáceo caracterizado pelas folhas imparipinadas, inflorescência racemosa, flores com pétalas variando de róseas a avermelhadas, androceu com dez estames (diadelfos) e fruto do tipo legume. Indigofera é um gênero pantropical com cerca de 700 espécies, sendo 15 nativas da América do Sul. É encontrado em florestas estacionais, florestas temperadas, savana estépica, áreas perturbadas e em bordas de florestas (Lewis et al. 2005). Na Serra de Baturité foram encontradas três espécies.

\section{Chave de identificação das espécies de Indigofera da Serra de Baturité}

1. Folíolos com até $5 \mathrm{~mm}$ de largura e com glândulas amarelas na face abaxial I. microcarpa

1'. Folíolos com mais de $10 \mathrm{~mm}$ de largura e sem glândulas.

2. Racemos aproximadamente 2 vezes maior que as folhas; frutos retos

I. blanchetiana

2'. Racemos quase sempre menores que as folhas; frutos arqueados

I. suffruticosa

108. Indigofera blanchetiana Benth., Fl. bras. 15(1A): 40. 1859.

Espécie subarbustiva ou arbustiva, folhas com aproximadamente 12 folíolos, inflorescência racemosa, flores com pétalas róseas, estandarte oboval e fruto do tipo legume. A espécie apresenta tricomas malpighiáceos com braços de tamanhos desiguais ao longo do eixo foliar e da inflorescência. É encontrada nos estados do Piauí, Ceará, Bahia e Minas Gerais. Na Serra de Baturité foi encontrada em áreas a sotavento. Material examinado: Baturité, 10.IV.1909, fl. e fr., $A$. Ducke (RB 12214).

109. Indigofera microcarpa Desv., J. Bot. Agric. 3:79. 1814.

Espécie herbácea prostrada caracterizada pelas folhas com sete a nove folíolos obovais, ápice arredondado e face abaxial com glândulas amarelas, inflorescência racemosa, flores com pétalas róseas e fruto do tipo legume (menor que $1 \mathrm{~cm}$ de comprimento).
Espécie pantropical. Na Serra de Baturité foi encontrada em áreas a sotavento.

Material examinado: Baturité, 20.X.1979, fl. e fr., $E$. Nunes et al. (EAC 7176).

110. Indigofera suffruticosa Mill., Gard. Dict. (ed. 8) no. 2. 1768 .

Fig. 8s-u

Espécie subarbustiva ou arbustiva caracterizada pelas folhas pinadas com mais de dez folíolos com face adaxial glabra, inflorescência racemosa, flores vermelhas e fruto do tipo legume. É encontrada em áreas antropizadas da América tropical e subtropical, sendo amplamente distribuída no Brasil (Moreira \& Tozzi 1997). Na Serra de Baturité é encontrada em áreas de florestas estacionais e ombrófilas.

Material examinado: Aratuba, 14.V.1980, P. Martins et al. (EAC 8576). Baturité, 14.X.1995, L.W. Lima-Verde (EAC 25278). Capistrano, 16.X.1979, fl., E. Nunes et al. (EAC 7084). Mulungu, 19.IX.2007, J.R. Lima 183 (EAC, RB). Pacoti, 9.II.2007, fr., J.R. Lima 126 (EAC, RB). 
Lonchocarpus Kunth, Nov. Gen. Sp. (folio ed.) 6: 300. 1824.

Gênero arbóreo caracterizado pelas folhas imparipinadas com número de folíolos variando de cinco a nove, inflorescência pseudoracemosa, pétalas brancas, lilases ou roxas e androceu com dez estames soldados em tubo, pseudomonadelfos, com duas aberturas na base e frutos indeiscentes. Lonchocarpus é um gênero neotropical com cerca de 120 espécies, sendo que $L$. sericeus é encontrada também na África. É observado em Florestas Estacionais e Ombrófilas e em áreas de Savana Estépica (Azevedo-Tozzi 1989). Na Serra de Baturité foram encontradas apenas duas espécies.

\section{Chave de identificação das espécies de Lonchocarpus da Serra de Baturité}

1. Folíolos com 10-11 pares de nervuras secundárias; fruto com margem superior estreitamente alada ... L. sericeus

1'. Folíolos com 4 a 7 pares de nervuras secundárias; fruto sem ala marginal L. araripensis

111. Lonchocarpus araripensis Benth., J. Linn. Soc., Bot. 4 (Suppl.): 96. 1860.

Espécie arbórea de até $15 \mathrm{~m}$ de altura caracteriza pelas folhas com folíolos glabros (sete a nove), inflorescência paniculada, flores com pétalas lilases e fruto do legume. L. araripensis éencontrada apenas no Nordeste, sendo considerada endêmica de savana estépica (Cardoso \& Queiroz 2007). Na Serra de Baturité foi encontrada em área de floresta estacional. Material examinado: Mulungu, 14.VII.2007, J.R. Lima 684 (EAC, RB).

112. Lonchocarpus sericeus (Poir.) DC., Prodr. 2: 260. 1825 . Fig. 9a-e

Espécie arbórea de até $15 \mathrm{~m}$ de altura, folhas com folíolos glabros na face adaxial e pubescente na abaxial, inflorescência pseudoracemosa, axilar, flores com pétalas lilases, estandarte seríceo na face externa e legume, densamente velutino, com margem superior estreitamente alada. L. sericeus é reconhecida pela combinação de hábito arbóreo e inflorescência axilar congesta e flores com pétalas lilases. Espécie pantropical bem distribuída no Neotrópico (AzevedoTozzi 1989). Na Serra de Baturité é encontrada em áreas de florestas estacional e ombrófila.

Material examinado: Baturité, 20.X.1979, fl., A.J. Castro et al. (EAC 7177). Guaramiranga, 9.X.2007, fl., E. Silveira et al. (EAC 41638). Mulungu, 24.I.2009, fl., J.R. Lima 717 (RB). Pacoti, 18.IX.2007, J.R. Lima 170(EAC, RB). Palmácia, 8.X.1980, E. Nunes et al. (EAC 8940).

Machaerium Pers., Syn. Pl. 2(2): 276. 1807.

Gênero arbóreo, arbustivo ou escandente caracterizado pelas folhas imparipinadas, folíolos alternos, estípulas espinescentes, flores com pétalas, em geral, lilases, externamente pubescentes, androceu monadelfos, dez estames e fruto do tipo sâmara com semente basal e ala distal. Machaerium é um gênero pantropical com cerca de 130 espécies (Lewis et al. 2005). Ocorre em florestas pluviais inundáveis e não inundáveis, florestas estacionais, vegetação sobre dunas, vegetação arbustivas e savana estépica. na Serra de Baturité foram encontradas duas espécies.

\section{Chave de identificação das espécies de Machaerium da Serra de Baturité}

1. Arbórea; estípulas espinescentes retilíneas; folha com mais de 30 folíolos M. hirtum

1'. Escandente; estípulas espinescentes recurvadas; folha com menos de 20 folíolos M. amplum

113. Machaerium amplum Benth., Comm. Legum. Gen. 33. 1837. Fig. 9f-j

Espécie reconhecida pelo hábito escandente, folíolos elípticos ou oblongos com base arredondada e ápice retuso, estípulas espinescentes recurvadas e flores com pétalas roxas. Distribui-se da Amazônia até o estado de São Paulo (Sartori \&
Tozzi 1998). Na Serra de Baturité é encontrada em áreas de florestas estacionais e ombrófilas.

Material examinado: Aratuba, 9.X.2007, fl.,J.R. Lima (EAC 42112). Baturité, 27.VII.1908, fl., A. Ducke 1456 (RB). Pacoti, 10.VII.2008, fl., J.R. Lima 641 (RB). Material adicional: GOIÁS: Goiânia, 13.VII.1964, fr., A.E. Mattos 415 (RB). 


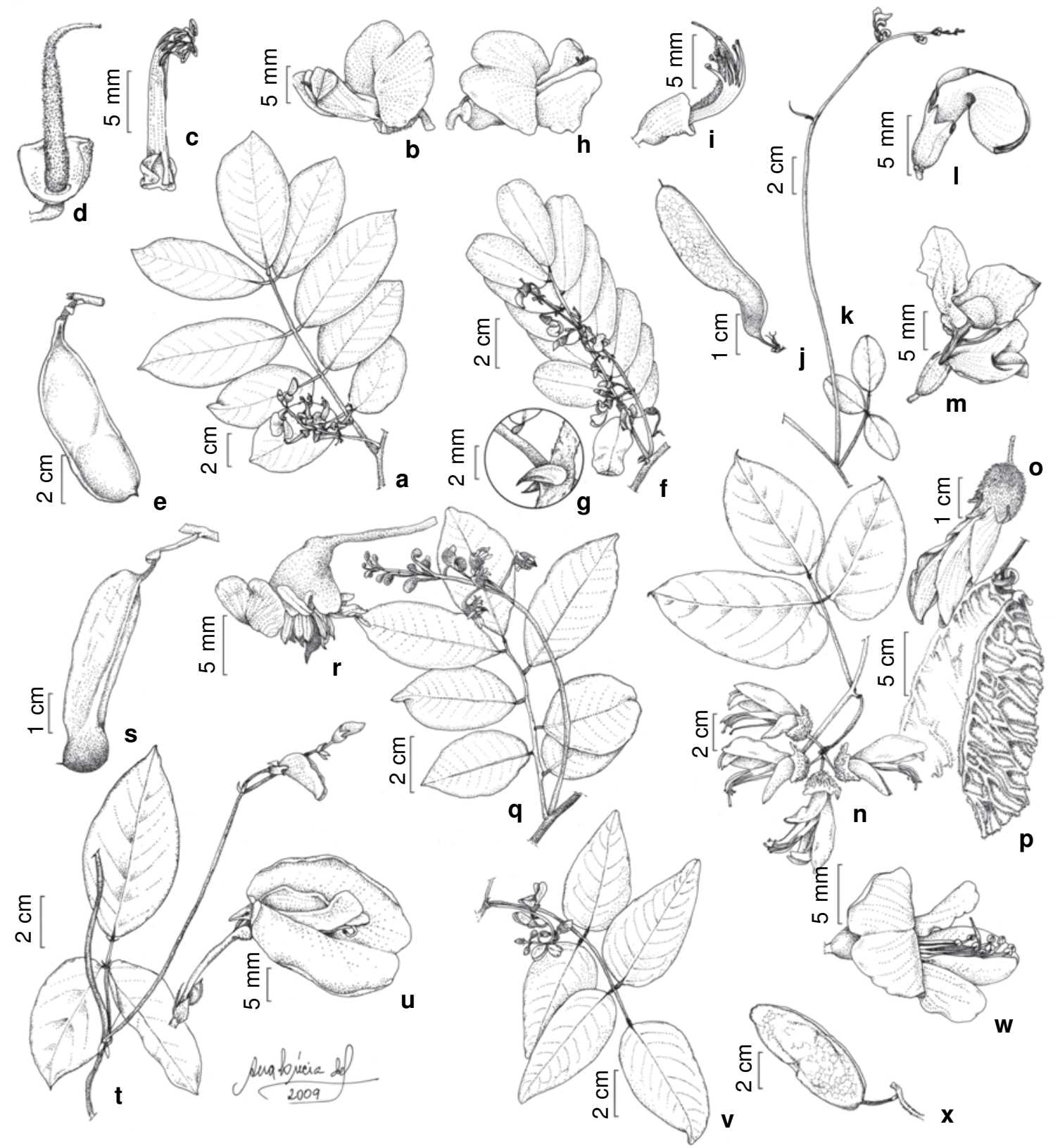

Figura 9 - a-e. Lonchocarpus sericeus (Poir.) Kunth ex DC. - a. ramo com inflorescência; b. flor; c. androceu; d. gineceu (J.R. Lima 717); e. fruto (J.R. Lima 191). f-j. Machaerium amplum Benth. - f. ramo com inflorescên cia; g. estípula espinescente; h. flor; i. androceu (J.R. Lima 641); j. fruto (A.E. Mattos 415).k-m. Macroptilium lathyroides (L.) Urban - k. ramo com inflorescência; 1-m. flor (L.C.O. Filho \& J.C.A. Lima 105). n-p. Mucuna sloanei Fawc. \& Rendlen. ramo com inflorescência;o. flor (J.R. Lima 666); p. fruto (J.R. Lima 346 ). q-s. Myroxylon peruiferum L. f. - q. ramo com inflorescência; r. flor (R.D. Ribeiro 661 et al.); s. fruto (J.G. Kulmamm - RB 16564).t-u. Periandra coccinea (Schrader) Benth. - t. ramo com inflorescência; u. flor (J.R. Lima 653). v-x. Platymiscium floribundum var. nitens (Vogel) Klitgaard - v.ramo com inflorescência; w. flor (J.R. Lima 173); x. fruto (J.R. Lima 679).

Figure 9 - a-e. Lonchocarpus sericeus (Poir.) Kunth ex DC. - a. branch with inflorescence; b. flower; c. androecium; d. gynoecium; e. fruit. f-j. Machaerium amplum Benth. - f. branch with inflorescence; g. thorny stipule; h. flower; i. androecium; j. fruit. k-m. Macroptilium lathyroides (L.) Urban - k. branch with inflorescence; 1-m. flower. n-p. Mucuna sloanei Fawc. \& Rendle - n. branch with inflorescence; o. flower; p. fruit. Myroxylon peruiferum L. f. - q. branch with inflorescence; r. flower; s. fruit. t-u. Periandra coccinea (Schrader) Benth. - t. branch with inflorescence; u. flor. v-x. Platymiscium floribundum var. nitens (Vogel) Klitgaard - v. branch with inflorescence; w. flor; x. fruit. 
114. Machaerium hirtum (Vell.) Stellfeld, Tribuna Farm. 14(12):246. 1946.

Espécie arbórea facilmente reconhecida vegetativamente pelas estípulas espinescentes retilíneas, folíolos estreito-oblongos e ápice obtuso. Espécie amplamente distribuída na América do Sul. $\mathrm{Na}$ Serra de Baturité é encontrada em áreas de florestas estacional e ombrófila.

Material examinado: Guaramiranga, 2.XI.1998, A.S.F. Castro (EAC 27206). Mulungu, 19.IX.2007, fl., J.R. Lima 187 (EAC, RB). Pacoti, 23.VI.1990, M.A. Figueiredo s.n. (EAC 17453).

Macroptilium (Benth.) Urb., Symb. Antill. 9(4): 457. 1928.

Gênero herbáceo ou subarbustivo caracterizado pelas folhas trifolioladas, inflorescência pseudoracemosa nodosa, flores com alas maiores que as outras pétalas e carena retorcida, androceu com dez estames (diadelfos) e fruto do tipo legume. Macroptilium é um gênero neotropical com cerca de 17 espécies, concentradas principalmente na América do Sul tropical, ocorrendo em florestas tropicais e subtropicais, savana estépica, áreas perturbadas e de pastagens (Lewis et al. 2005). Na Serra de Baturité foi encontrada apenas uma espécie.

115. Macroptilium lathyroides (L.) Urban, Symb. Antill. 9(4): 457. 1928.

Fig. 9k-m

Espécie herbácea ou subarbustiva reconhecida pela combinação de folhas trifolioladas, inflorescência pseudoracemosa com as brácteas ausentes na base, porém persistentes no ápice e flores com as alas maiores que as outras pétalas e carena retorcida. Espécie neotropical considerada invasora. Na Serra de Baturité foi encontrada em áreas a sotavento.

Material examinado: Baturité, 1937, fl., J.E. Leite 666 (RB). Material adicional: BAHIA: Livramento do Brumado, 19.III.1984, fl., L.C.O. Filho \& J.C.A. Lima 105 (RB).

\section{Mucuna Adans., Fam. Pl. 2: 325, 579. 1763.}

Gênero lianescente reconhecido pelas folhas trifolioladas, flores com estandarte mais curto que as carenas e frutos do tipo legume com tricomas urticantes. Mucuna é um gênero pantropical com cerca de 105 espécies, 12-13 espécies no Neotrópico (Lewis et al. 2005) e cinco no Brasil (Tozzi et al. 2005). frequentemente encontrado em áreas de floresta ombrófila densa atlântica e floresta estacional. na Serra de Baturité foi encontrada apenas uma espécie.
116. Mucuna sloanei Fawc. \& Rendle, J. Bot. 55(650):36. 1917.

Fig. 9n-p

M. sloanei é facilmente reconhecida pela combinação de folhas trifolioladas pubescente na face abaxial, flores amarelas com estandarte menor que as outras pétalas, fruto ornamentado e recoberto por tricomas urticantes. É encontrada na África, Caribe e nas Américas. $\mathrm{Na}$ América do Sul é observada na Argentina, Brasil, Colômbia, Guiana Francesa, Guiana, Peru e Suriname (Tozzi et al. 2005). Na Serra de Baturité foi encontrada em áreas antropizadas próximas a floresta ombrófila.

Material examinado: Mulungu, 11.VII.2008, fl., J.R. Lima 666 (EAC, RB).

Myroxylon L. f., Suppl. Pl. 34, 233. 1781 [1782].

Gênero arbóreo caracterizado pelas folhas pinadas alternas com folíolos com listras e pontos translúcidos, inflorescência racemosa, flores com cinco pétalas e androceu com estames livres. Gênero neotropical com três espécies (Sartori 2000), ocorrendo em floresta ombrófila de terras baixas e floresta estacional (Lewis et al. 2005). Na Serra de Baturité foi encontrada uma espécie.

117. Myroxylon peruiferum L. f., Suppl. Pl. 233. 1781 [1782]. $\quad$ Fig. 9q-s

Myroxylon peruiferum é facilmente reconhecida na Serra de Baturité pela combinação de pontos e listras translúcidas nos folíolos e fruto do tipo sâmara com semente distal e asa proximal. É encontrada no México, Honduras, Colômbia, Peru, Bolívia, Argentina, Brasil e Equador, em áreas de savana estépica, savana, floresta ombrófila densa amazônica e atlântica (Sartori 2000). Na Serra de Baturité é encontrada em áreas de floresta ombrófila.

Material examinado: Guaramiranga, 03.XI.2001,A.S.F. Castro (EAC 31135).

Material adicional: RIO DE JANEIRO: Quissamã, 7.V.2006, fl., R.D. Ribeiro 661 et al.(RB). Rio de Janeiro, 20.IX.1922, fr., J.G. Kulmamm s.n. (RB 16564).

Periandra Mart. ex Benth., Comm. Legum. Gen. 56. 1837.

Gênero com espécies arbustivas, subarbustivas, herbáceas e trepadeiras caracterizadas pela inflorescência racemosa ou cimosa, flores com cálice campanulado, com pétalas azuis ou vermelhas e fruto do tipo legume. Gênero sul-americano com seis espécies (Funch \& Barroso 1999). Na Serra de Baturité foi encontrada uma espécie. 
118. Periandra coccinea (Schrad.) Benth., Comm. Legum. Gen. 58. 1837. Fig. 9t-u

Periandra coccinea é reconhecida pela combinação de hábito escandente, folhas trifolioladas, inflorescência cimosa, axilar, flores ressupinadas com pétalas vermelhas, estandarte suborbiculado e alas estreitas. Ocorre na BA, CE, GO, MA, MT, MG, PA, PE, PI, RR, TO e DF (Funch \& Barroso 1999). É encontrada em campo rupestre e Savana, frequentemente em ambientes perturbados (Funch \& Barroso 1999). $\mathrm{Na}$ Serra de Baturité é encontrada em áreas de floresta ombrófila.

Material examinado: Guaramiranga, 17.V.1959, fl., A. Fernandes (EAC 1877). Pacoti, 10.VII.2008, fl., J.R. Lima 653 (EAC, RB).

Platymiscium Vogel, Linnaea 11: 198-199. 1837.

Gênero arbóreo com folhas imparipinadas, opostas, inflorescência racemosa, flores com pétalas amarelas e fruto do tipo sâmara com semente em posição central. Platymiscium é um gênero neotropical com 19 espécies distribuídas desde o México até o Sul do Brasil, ocorrendo nas florestas ombrófila, estacional, savana e savana estépica (Lewis et al. 2005). Na Serra de Baturité foi encontrada uma espécie.
119. Platymiscium floribundum Vogel, Linnaea 11: 199.1837

119.1 Platymiscium floribundum var. nitens (Vogel) Klitgaard, Kew Bull. 54(4): 971. 1999.

Fig. 9v-x

Árvore reconhecida pela presença de folhas opostas, folíolos glabros, inflorescência racemosa com flores amarelas e sâmara com semente central. É encontrada no Nordeste, principalmente nas floresta ombrófila e estacional (Klitgaard 1995). Na Serra de Baturité é encontrada em áreas de floresta estacional.

Material examinado: Baturité, fr., F.F. Allemão s.n. (R 64412). Guaramiranga, 21.IX.2007, fl., J.R. Lima 234(EAC, RB). Mulungu, 19.IX.2007, J.R. Lima 171 (EAC, RB). Pacoti, 5.X.1990, fl., F.S. Cavalcanti et al. (EAC 16929).

Rhynchosia Lour., Fl. Cochinch 425, 460. 1790.

Gênero com espécies herbáceas, subarbustivas e trepadeiras caracterizadas pelas folhas trifolioladas, folíolos com pontuações glandulares amarelas na face abaxial, inflorescência racemosa axilar, flores com pétalas amarelas e fruto do tipo legume. Rhynchosiaé um gênero pantropical com cerca de 230 espécies, cerca de 55 endêmicas da América (Lewis et al. 2005). Na Serra de Baturité foram encontradas duas espécies.

\section{Chave de identificação das espécies de Rhynchosia da Serra de Baturité}

1. Folíolos $<4 \mathrm{~cm}$ de comprimento; frutos compressos; sementes marrom-esverdeadas R. minima

1'. Folíolos $>4 \mathrm{~cm}$ de comprimento; frutos não compressos; sementes vermelhas e pretas R. phaseoloides

120. Rhynchosia minima (L.) DC., Prodr. 2: 385.1825. Espécie trepadeira caracterizada pelos folíolos pequenos $(<4 \mathrm{~cm})$, fruto pubescente não constrito entre as sementes e sementes de coloração uniforme marrom-esverdeadas. $R$. minima é uma espécie pantropical considerada invasora em lugares antropizados (Grear 1978). Na Serra de Baturité é encontrada em áreas de floresta estacional.

Material examinado: Baturité, 14.X.1975, A. Fernandes (EAC 2600).

121. Rhynchosia phaseoloides (Sw) DC., Prodr. 2: 385.1825. Fig. 10a-c

Espécie trepadeira facilmente reconhecida por apresentar frutos não compressos, constrito entre as sementes vermelhas e pretas. É encontrada na América Central e América do Sul. Na Serra de Baturité é encontrada em áreas de floresta estacional e ombrófila.

Material examinado: Aratuba, 15.V.1980, P. Martins et al. (EAC 8627). Pacoti, 13.XI.2007, fl., J.R. Lima 372 (EAC, RB).

Sesbania Scop., Intr. Hist. Nat. 308-309. 1777.

Gênero arbóreo, arbustivo e herbáceo com folhas paripinadas (mais de 20 pares) e legume estreitamente linear, aproximadamente cilíndrico. Sesbania é um gênero pantropical com cerca de 60 espécies, oito ocorrendo no Brasil (Monteiro 1994). Na Serra de Baturité foi encontrada uma espécie. 
122. Sesbania exasperata Kunth, Nov. Gen. Sp. (quarto ed.) 6: 534-535. 1823 [1824]. Fig. 10d-f

Sesbania exasperata é reconhecida pela combinação do hábito arbustivo, folhas paripinadas, flores amarelas e legume estreitamente linear, aproximadamente cilíndrico. É encontrada na América Central (Nicarágua e Panamá) e América do Sul. Na Serra de Baturité é encontrada em áreas de floresta ombrófila.

Material examinado: Baturité, 10.V.2001, fl., A. Fernandes (EAC 25252).

Material adicional: PERNAMBUCO: Mirandiba, 20.VI.2007, fl. e fr., E. Córdula 291 (RB, HUEFS, UFP).
Stylosanthes Sw., Prodr. 7, 108. 1788.

Gênero herbáceo e subarbustivo reconhecido pela combinação de folhas trifolioladas, estípulas adnatas ao pecíolo, flores sésseis com pétalas amarelas, glabras, alas e carena aproximadamente do mesmo comprimento, hipanto alongado, androceu com dez estames (monadelfo), cinco estames férteis alternando com cinco estaminódios e fruto do tipo lomento. Stylosanthes é um gênero pantropical com cerca de 25 espécies (Ferreira \& Costa 1979; Mohlenbrock 1957). Na Serra de Baturité foram encontradas três espécies.

\section{Chave de identificação das espécies de Stylosanthes da Serra de Baturité}

1. Folíolos elípticos. Inflorescência séssil ................................................................................ S. scabra

1'. Folíolos oblongos a estreitamente elípticos. Inflorescência pedunculada.

2. Artículo superior do lomento maior que $3 \mathrm{~mm}$ S. humilis

2'. Artículo superior do lomento menor que $3 \mathrm{~mm}$ S. guianensis

123. Stylosanthes guianensis (Aubl.) Sw., Kongl. Vetensk. Acad. Nya Handl. 10: 301-302. 1789.

Espécie arbustiva e subarbustiva com caracteres que a aproxima de S. humilis, no entanto, se diferencia desta por apresentar o artículo superior do lomento menor que $3 \mathrm{~mm}$. $S$. guianensis é a que possui distribuição mais ampla e também a maior variabilidade no gênero (Costa 2006). No Brasil é encontrada no CE, PB, PE, BA, DF, GO, MG, RJ, SP e PR (Ferreira \& Costa 1979). $\mathrm{Na}$ Serra de Baturité é encontrada em áreas de floresta estacional.

Material examinado: Baturité, 4.IX.1939, fl., J.E. Leite 689 (RB 44732).

124. Stylosanthes humilis Kunth, Nov. Gen. Sp. (quarto ed.) 6: 506, pl. 594. 1823 [1824]. Fig. 10g-i

Espécie herbácea ou subarbustiva, folhas trifolioladas, folíolos oblongos, inflorescência espiciforme curta, pedunculada, flores amarelas, fruto do tipo lomento com o rostro (resquício do estilete) recurvado e mais longo que o artículo terminal. S. humilis é uma espécie neotropical encontrada em áreas de floresta estacional, savana estépica e savana (Costa 2006). Na Serra de Baturité é encontrada em áreas de florestas estacionais. Material examinado: Baturité, 17.V.1959, A. Fernandes (EAC 1872). Mulungu, 18.IV.2008, fl., J.R. Lima 535 (RB).
125. Stylosanthes scabra Vogel, Linnaea 12: 6970. 1838.

Espécie subarbustiva reconhecida pelas folhas trifolioladas, folíolos elípticos, inflorescência espiciforme séssil, flores amarelas e fruto do tipo lomento com rostro recurvado mais curto que o artículo distal. S. scabra é encontrada na América do Sul, amplamente distribuída no Brasil (Ferreira \& Costa 1979). Na Serra de Baturité é encontrada em áreas de floresta estacional.

Material examinado: Baturité, fl., J.E. Leite s.n. (RB 112864). Mulungu, 19.IX.2007, J.R. Lima 180 (EAC, RB).

Trischidium Tul., Ann. Sci. Nat. Bot., sér. 2, 20: 141. 1843.

Gênero arbóreo ou arbustivo caracterizado pelas folhas imparipinadas, folíolos (mais de cinco) alternos, flores com uma pétala, androceu com mais de dez estames livres e fruto do tipo legume, elíptico e inflado. Trischidium é um gênero sul-americano com cinco espécies (Lewis et al. 2005). Na Serra de Baturité foi encontrada apenas uma espécie.

126. Trischidium molle (Benth.) $\mathrm{H}$. Ireland, Kew Bull. 62 (2):336. $2007 . \quad$ Fig. 10j-k

Espécie arbórea reconhecida pela combinação de folhas imparipinadas com o número de folíolos variando de 5 a 9 , inflorescência racemosa, flores com uma pétala branca, androceu polistêmone, 


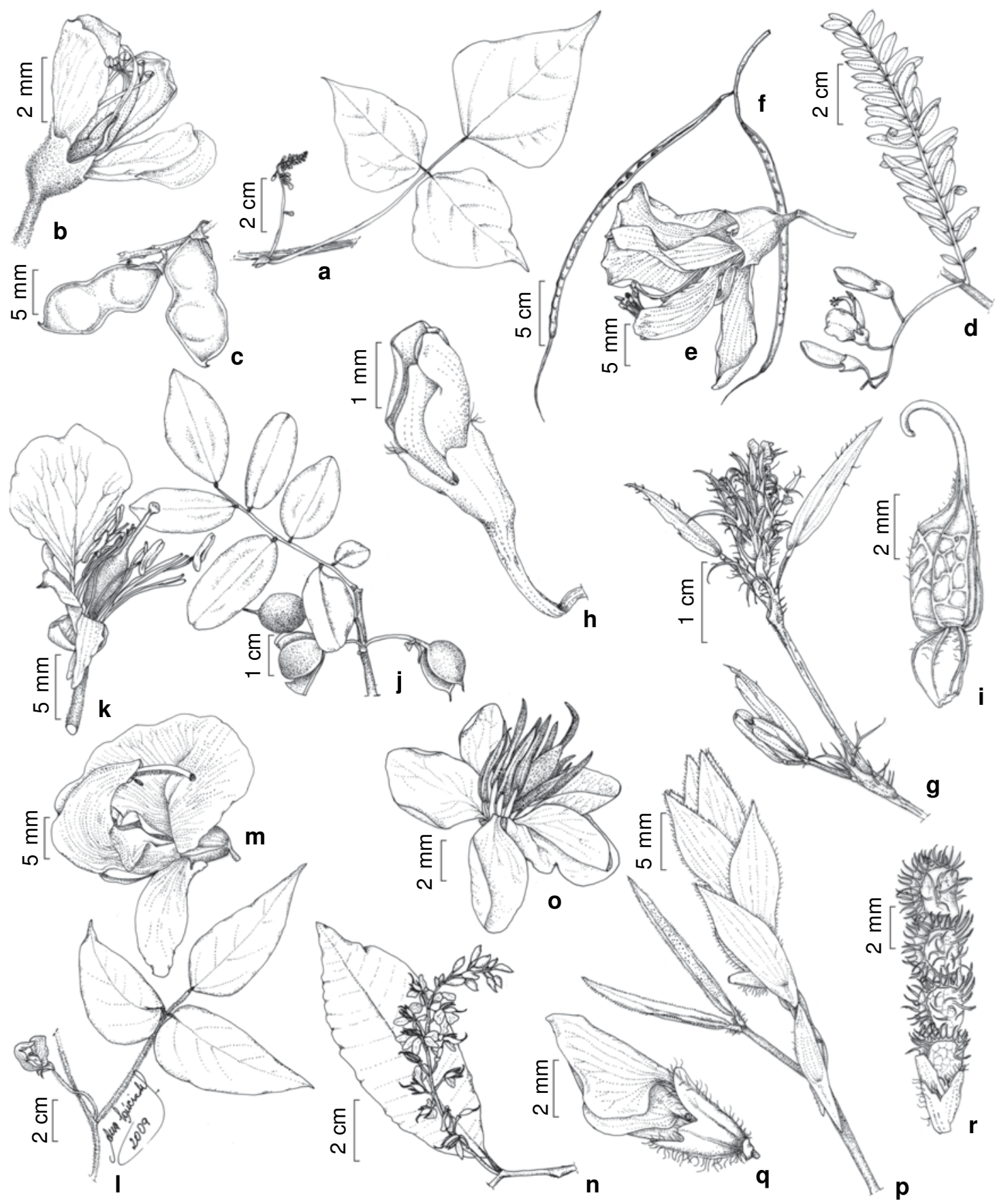

Figura 10 - a-c. Rhynchosia phaseoloides (Sw) DC. - a. ramo com inflorescência; b. flor (J.R. Lima 372); c. frutos (J.R. Lima 367). d-f. Sesbania exasperata Kunth-d. ramo com inflorescência; e. flor (E. Córdula 291); f. frutos (J.E. Leite 644). g-i. Stylosanthes humilis Kunth - g. ramo com inflorescência; h. flor; i. fruto (J.R. Lima 535).j-k. Trischidium molle (Benth.) H. Ireland-j. ramo com frutos; k. flor (L. P. Gonzaga 50). 1-m. Vigna vexillata (L.) A. Rich. - 1. ramo com flor (G.C. pinto 332/83); m. flor (J.R. Lima 204). n-o. Zollernia paraensis Huber - n. ramo com inflorescência; o. flor (W.A. Egler \& H.S. Irwin - RB 128740). p-r. Zornia latifolia Sm. - p. ramo com inflorescência; q. flor; r. fruto (J.R. Lima 546).

Figure 10 - a-c. Rhynchosia phaseoloides (Sw) DC. - a. branch with inflorescence; b. flower; c. fruits. d-f. Sesbania exasperata Kunth d. branch with inflorescence; e. flower; f. fruits. g-i. Stylosanthes humilis Kunth - g. branch with inflorescence; h. flower; i. fruit. j-k. Trischidium molle (Benth.) H. Ireland - j. branch with fruits; k. flower. 1-m. Vigna vexillata (L.) A. Rich. - 1. flowering branch; m. flower. n-o. Zollernia paraensis Huber $-\mathrm{n}$. branch with inflorescence; o. flower. p-r. Zornia latifolia $\mathrm{Sm}$. - p. branch with inflorescence; q. flower; r. fruit. 
anteras uniformes e frutos elipsóides. Espécie considerada endêmica da Savana Estépica (Cardoso \& Queiroz 2007), encontrada no Ceará, Pernambuco, Bahia e norte de Minas Gerais (Ireland 2007). Na Serra de Baturité é encontrada em áreas de floresta estacional.

Material examinado: Baturité, 12.IV.1909, fr., A. Ducke (MG 1980). Capistrano, 9.III.1994, J.B.L.P. Medeiros et al. (EAC 21573).

Material adicional: BAHIA: Canudos, 12.VIII.1985, fr., L.P. Gonzaga 50 (RB).

Vigna Savi, Nuovo Giorn. Lett. 8: 113. 1824.

Gênero com espécies trepadeiras, folhas trifolioladas, folíolos laterais assimétricos, inflorescência pseudoracemosa nodosa, flores, em geral, com pétalas lilases, estandarte oboval, carena ligeiramente falcada a espiraladamente torcida, androceu com dez estames (diadelfo), anteras uniformes e fruto do tipo legume. Vigna é um gênero pantropical com cerca de 104 espécies, encontrado em áreas de floresta estacional e savana estépica (Lewis et al. 2005). Na Serra de Baturité foi encontrada uma espécie.

127. Vigna vexillata (L.) A.Rich., Hist. Fis. Cuba, Bot. 10: 191. 1845. Fig. 101-m

Espécie trepadeira reconhecida pela inflorescência pseudoracemosa nodosa, flores com alas não retorcidas aproximadamente do mesmo tamanho que o estandarte e carena retorcida. É encontrada na Bahia, Minas Gerais, Rio de Janeiro e São Paulo, sendo registrada pela primeira vez para o Ceará no presente estudo. $\mathrm{Na}$ Serra de Baturité é encontrada nas áreas de florestas estacional e ombrófila.

Material examinado: Baturité, 1937, J.E. Leite 667 (RB). Pacoti, 13.XI.2007, fl., J.R. Lima 384 (EAC, RB). Material adicional: BAHIA: Salvador, 27.10.1983, fl. e fr., G.C. Pinto 332/83 (RB).

Zollernia Wied-Neuw. \& Nees, Nova Acta Phys.Med. Acad. Caes. Leop.-Carol. Nat. Cur. 13(2): Praef 13-14. 1826.

Gênero arbóreo e arbustivo caracterizado pelas folhas simples, flores, em geral, com cálice inteiro no botão floral, corola com cinco pétalas subiguais e estames com filetes menores que as anteras. Zollernia é um gênero sul-americano com 10 espécies (Mansano et al. 2004). É encontrado em áreas de floresta ombrófila densa amazônica e atlântica, floresta estacional, savana, savana estépica e restinga. Na Serra de Baturité foi encontrada uma espécie.
128. Zollernia paraensis Huber, Bol. Mus. Paraense Hist. Nat. 6: 81. $1910 . \quad$ Fig. 10n-o

Espécie arbórea facilmente reconhecida pelas folhas simples, estípulas caducas, flores róseas, não papilionácea s e legume nucóide. É frequentemente encontrada na floresta ombrófila densa amazônica (mata de terra firme), sendo também encontrada no Maranhão e no Ceará (Mansano et al. 2004). $\mathrm{Na}$ Serra de Baturité é encontrada em áreas de floresta estacional.

Material examinado: Baturité, Sítio Caridade, 7.IX.1938, fl., J.E. Leite 1179 (RB).

Material adicional: AMAPÁ: Rio Jarí, fl., 25.VI.1961, W.A. Egler \& H.S. Irwin (RB 128740).

Zornia J.F. Gmel., Syst. Nat. 2 (2): 1076, 1096. 1791 [1792].

Gênero herbáceo ou subarbustivo caracterizado pela folhas com um ou dois pares de folíolos opostos, inflorescências espiciformes ou flores isoladas, flores sésseis com pétalas amarelas, androceu com dez estames e frutos do tipo lomento. Gênero pantropical com cerca de 75 espécies, sendo 41 delas nativas das Américas das quais 27 ocorrem no Brasil (Mohlenbrock 1961). Na Serra de Baturité foi encontrada uma espécie.

129. Zornia latifolia Sm Cycl. 39: no. 4. 1819.

Fig. 10p-r

Espécie subarbustiva reconhecida pela combinação de folhas bifolioladas, inflorescências espiciformes, congestas, flores amarelas e fruto do tipo lomento com artículos pubescentes. Espécie de ampla distribuição na América do Sul, desde a Venezuela até o Uruguai e Argentina e oeste da África (Mohlenbrock 1961). Na Serra de Baturité é encontrada em áreas de florestas estacional e ombrófila.

Material examinado: Guaramiranga, 12.II.1981, A. Fernandes et al. (EAC 9660). Mulungu, 18.IV.2008, fl. e fr., J.R. Lima 546 (EAC, RB).

\section{Agradecimentos}

Os autores agradecem aos curadores dos herbários consultados, à Funcap (Fundação Cearense de Apoio ao Desenvolvimento Científico e Tecnológico) e ao CNPq (Conselho Nacional de Desenvolvimento Científico e Tecnológico), o apoio financeiro através da bolsa de Doutorado e a todos os participantes do Laboratório de Fitogeografia da Universidade Federal do Ceará, em especial a Francisca Soares de Araújo, o apoio logístico e ao 
botânico Luiz Wilson Lima-Verde, o valioso apoio nas viagens de campo. A Ana Lucia Souza e Maria Alice, as ilustrações botânicas.

\section{Referências}

Andrade, K.V.S.A. \& Rodal, M.J.N. 2004. Fisionomia e estrutura de um remanescente de floresta estacional semidecidual de terras baixas no nordeste do Brasil. Revista Brasileira de Botânica 27: 463-474.

Andrade-Lima, D. 1982. Present-day forest refuges in northeastern Brazil. In: Prance, G.T. (ed.). Biological diversification in the tropics. Columbia University Press, New York. Pp. 245-251.

Araújo, F.S. \& Martins, F.R. 1999. Fisionomia e organização da vegetação do carrasco no planalto da Ibiapaba, estado do Ceará. Acta Botanica Brasilica 13: 1-14.

Araújo, F.S.; Santos, V.G.; Silveira, A.P.; Figuieredo, M.A.; Oliveira, R.F.; Bruno, M.M.A.; Lima-Verde, L.W. \& Silva, E.F. 2006. Efeito da variação topoclimática na fisionomia e estrutura da vegetação da Serra de Baturité, Ceará. In: Oliveira, T.S. \& Araújo, F.S (orgs.). Biodiversidade do Maciço de Baturité. UFC/COELCE, Fortaleza. Pp. 137-162.

Azevedo, A.M.G. 1981. O gênero Desmodium Desv. no Brasil: considerações taxonômicas. Dissertação de Mestrado. Universidade Estadual de Campinas, Campinas. 315p.

Azevedo-Tozzi, A.M.G. 1989. Estudos taxonômicos nos gêneros Lonchocarpus Kunth e Deguelia Aubl. no Brasil. Tese de Doutorado. Universidade Estadual de Campinas, Campinas. 348p.

Barneby, R.C. 1991. Sensitivae Censitae, a description of the genus Mimosa L. (Mimosaceae) in the New World. Memoirs of the New York Botanical Garden 65: 1-835.

Barneby, R.C. 1998. Silky tree, guanacaste, monkey's earring: a generic system for the synandrous Mimosaceae of the Americas. Memoirs of the New York Botanical Garden 74: 1-223.

Barneby, R.C. \& Grimes, J.W. 1996. Silky tree, guanacaste, monkey's earring - a generic system for the synandrous Mimosaceae of the Americas. Part I. Abarema, Albizia, and allies. Memoirs of the New York Botanical Garden 74: 1-292.

Bentham, G. 1859-1862. Papilionaceae. In:Martius, C.F.P.; Eichler, A.W. \& Urban, T. (eds.). Flora brasiliensis. Monachii, Lipsiae, Fridr. Fleischer. 15: 1-350.

Bentham, G. 1870. Swartzieae et Caesapinieae. In: Martius, C.F.P.; Eichler, A.W. \& Urban, T. (eds.). Flora brasiliensis. Monachii, Lipsiae, Fridr. Fleischer. 15: 1-254.

Bocage, A.L. 2005. O gênero Acacia Mill. (Leguminosae - Mimosoideae) no semiárido brasileiro. Tese Doutorado. Universidade Federal do Rio Grande do Sul, Porto Alegre. 131p.
Burkart, A. 1971. El género Galactia (Legume-Phaseoleae) en Sudamérica con especial referencia a la Argentina y paises vecinos. Darwiniana 16: 663-801.

Cardoso, D.B.O.S. \& Queiroz, L.P. 2007. Diversidade de Leguminosae nas caatingas de Tucano, Bahia: implicações para a fitogeografia do semi-árido do Nordeste do Brasil. Rodriguésia 58: 379-391.

Carvalho, A.M. 1997. A synopsis of the genus Dalbergia (Fabaceae: Dalbergieae) in Brazil. Brittonia 49: 87-109.

Cavalcante, A.M.B.; Soares, J.J. \& Figuieredo, M.A. 2000. Comparative phytosociology of tree sinusiae between contiguous forests in diferent stages of succession. Revista Brasileira de Biologia 60: 551-562.

Cestaro, L.A. \& Soares, J.J. 2004. Variações florística e estrutural e relações fitogeográficas de um fragmento de floresta decídua no Rio Grande do Norte, Brasil. Acta Botanica Brasilica 18: 203-218.

Costa, J.A.S.C. 2007. Filogenia do gênero Copaifera (Leguminosae, Caesalpinioideae) e taxonomia das espécies extra-amazônicas. Tese de Doutorado. Universidade Estadual de Feira de Santana, Feira de Santana. 249p.

Costa, N.M.S. 2006. Revisão do género Stylosanthes Sw (Leguminosae-Papilionoideae). Tese de Doutorado. Instituto Superior de Agronomia, Lisboa. 494p.

Dionísio, G.O. 2005. Leguminosas (Leguminosae Juss.) arbóreas na mata atlântica da Paraíba e do Rio Grande do Norte. Dissertação de Mestrado. Universidade Federal de Pernambuco, Recife. 61p.

Doyle, J.J. \& Luckow, M.A. 2003. The rest of the iceberg. Legume diversity and evolution in a phylogenetic context. Plant Physiology 131: 900-910.

Ducke, A. \& Black, G.A. 1953. Phytogeographical notes on the Brazilian Amazon. Anais da Academia Brasileira de Ciências 25: 1-46.

Fantz, P.R. 2001. Centrosema. In: Stevens, W.D.; Ulloa, C.; Pool, A. \& Montiel, O.M. (eds.). Flora de Nicaragua. Tomo 2: Angiospermas (Fabaceae-Oxalidaceae). Monographs in Systematic Botany from the Missouri Botanical Garden. Pp. 966-971.

Fernandes, A.G. 1996. O taxon Aeschynomene no Brasil. EUFC, Fortaleza. 128p.

Ferraz, E.M.N. \& Rodal, M.J.N. 2006. Caracterização fisionômica estrutural de um remanescente de floresta ombrófila montana de Pernambuco, Brasil. Acta Botanica Brasilica 9: 11-926.

Ferreira, M.B. \& Costa, N.M.S. 1979. O gênero Stylosanthes no Brasil. EPAMIG, Belo Horizonte. 107p.

Figueiredo, M.A. \& Barbosa, M.A. 1990. A vegetação e a flora na Serra de Baturité - Ceará. Coleção Mossoroense B: 110.

Funch, L.S. \& Barroso, G.M. 1999. Revisão taxonômica do gênero Periandra Mart. ex Benth. (Leguminosae, Papilionoideae, Phaseoleae). Revista Brasileira de Botânica 22: 339-356. 
Grear, J.W. 1978. A revision of the New World species of Rhynchosia (Leguminosae-Faboideae). Memoirs of the New York Botanical Garden 31: 1-168.

Hao, G.; Zhang, D.; Zhang, M.; Guo, L. \& Li, S. 2003. Phylogenetics of Bauhinia subgenus Phanera (Leguminosae: Caesalpinioideae) based on ITS sequences of nuclear ribosomal DNA. Botanical Bulletin of Academia Sinica. 44: 223-228.

Hernández, H. 1989. Systematics of Zapoteca (Leguminosae). Annals of the Missouri Botanical Garden 76: 781-862.

Holmgren, P.K. \& Holmgren, N.H. 1998. Onwards [continuously updated]. Index Herbariorum. New York Botanical Garden. Disponível em: <http:// sciweb.nybg.org/science2/IndexHerbariorum.asp >. Acesso em 20 Mar 2010.

Hopkins, M.J.G. \& Hopkins, H.C.F. 1983. The fruit and seed biology of the neotropical species of Parkia (Leguminosae: Mimosoideae). In: Sutton, S.L.; Whitmore, T.C. \& Chadwick, A.C. (eds.). Tropical rainforest: ecology and management. Oxford. Pp. 197-209.

Iganci, J.R.V. \& Morim, M.P. 2009. Abarema Pittier (Leguminosae, Mimosoideae) no estado do Rio de Janeiro, Brasil. Rodriguésia 60: 1-14.

Ireland, H.E. 2007. Taxonomic changes in the South American genus Bocoa(Leguminosae-Swartzieae): Reinstatement of the name Trischidium, and a synopsis of both genera. Kew Bulletin 62: 333-350.

Irwin, H.S. \& Barneby, R. 1982. The American Cassiinae. Memoirs of the New York Botanical Garden 35:1-918.

Jobson, R.W. \& Luckow, M. 2007. Phylogenetic study of the genus Piptadenia (Fabaceae: Mimosoideae) using Plastid trnL-F and trnK/matK sequence data. Systematic Botany 32: 560-575.

Klitgaard, B.B. 1995. Systematics of Platymiscium (Leguminosae: Papilionoideae: Dalbergieae): taxonomy, morphology, ontogeny, and phylogeny. Tese de Doutorado. University of Aarhus, Aarhus. 168p.

Lee, Y.T. \& Langenhein, J.H. 1975. Systemetics of the genus Hymenaea L. (Leg. Caesalpinioideae, Detarieae). University of California Publication in Botany 69: 1-109.

Lewis, G.P. 1987. Legumes of Bahia. Royal Botanic Gardens, Kew. 369p.

Lewis, G.P. 1998. Caesalpinia. A revision of the Poincianella-Erythrostemon Group. Royal Botanic Gardens, Kew. 233p.

Lewis, G.P. \& Rico Arce, M.L. 2005. Tribe Ingeae. In: Lewis, G.P.; Schrire, B.; Mackinder, B. \& Lock, M. (eds.). Legumes of the world. The Royal Botanic Gardens, Kew. Pp. 193-213.

Lewis, G.P.; Schrire, B.D.; Mackinder, B.A. \& Lock, J.M. 2005. Legumes of the world. Royal Botanic Gardens, Kew. 577p.

Lima, J.R.; Sampaio, E.V.S.B.; Rodal, M.J.N. \& Araújo, F.S. 2009. Composição florística e espectro biológico da floresta estacional decídua montana de Serra das Almas, Ceará, Brasil. Acta Botanica Brasílica 23: 756-763.

Mansano, V.F.; Azevedo-Tozzi, A.M.G. \& Lewis, G.P. 2004. A revision of the South American genus Zollernia Wied-Neuw. \& Nees (Leguminosae, Papilionoideae, Swartzieae). Kew Bulletin 59: 497-520.

Mesquita, A.L. 1990. Revisão taxonômica do gênero Enterolobium Mart. (Mimosoideae) para a região Neotropical. Dissertação de Mestrado. Universidade Federal Rural de Pernambuco, Recife. 222p.

MMA - Ministério do Meio Ambiente. 2000. Avaliação e ações prioritárias para a conservação da biodiversidade da floresta atlântica e campos sulinos. MMA/SBF, Brasília. 40p.

Mohlenbrock, R.H. 1957. A revision of the genus Stylosanthes. Annals of the Missouri Botanical Garden 44: 299-354.

Mohlenbrock, R.H. 1961. A monograph of the leguminous genus Zornia. Webbia 16: 1-141.

Monteiro, R. 1994. The species of Sesbania Scop. (Leguminosae) in Brazil. Brazilian Archives of Biology and Technology 37: 309-331.

Moreira, J.L.A. \& Tozzi, A.M.G.A. 1997. Indigofera L. (Leguminosae, Papilionoideae) no estado de São Paulo, Brasil. Revista Brasileira de Botânica 20: 97-117.

Oliveira-Filho, A.T. \& Fontes, M.A. 2000. Patterns of floristic differentiation among Atlantic forests in Southeastern Brazil and the influence of climate. Biotropica 32: 793-810.

Orchard, A.E. \& Maslin, B.R. 2003. Proposal to conserve the name Acacia (Leguminosae: Mimosoideae) with a conserved type. Taxon 52: 362-363.

Pennington, T.D. 1997. The genus Inga. Botany. Royal Botanic Gardens, Kew. 844p.

Polhill, R.M. 1982. Crotalaria in Africa and Madagascar. A.A. Balkema Publ., Rotterdam. 396p.

Polhill, R.M. \& Vidal, J.E. 1981. Caesalpinieae. In: Polhill, R.M. \& Raven, P.H. (eds.). 1981. Advances in legume systematics 1. Royal Botanic Gardens, Kew. Pp. 81-95.

Prado, D.E. \& Gibbs, P.E. 1993. Patterns of species distributions in the dry seasonal forest of South America. Annals of the Missouri Botanical Garden 80: 902-927.

Queiroz, L.P. 1999. Leguminosas de caatinga, espécies com potencial forrageiro. In: Araújo, F.D.; Prendesgast, H.D.V. \& Mayo, S.J. (eds.). Plantas do Nordeste: Anais do I Workshop Geral. Royal Botanic Gardens, Kew. Pp. 53-62.

Queiroz, L.P. 2006a. New species and new combinations in Phanera Lour. (Caesalpinioideae: Cercideae) from the Caatinga Biome. Neodiversity 1: 6-10.

Queiroz, L.P. 2006b. The Brazilian caatinga: phytogeographical patterns inferred from distribution data of 
the Leguminosae. In: Pennington, R.T. Lewis, G.P. \& Ratter, J.A. (eds.). Neotropical savannas and dry forests: plant diversity, biogeography, and conservation. Taylor \& Francis CRC-Press, Boca Raton. Pp 113-149.

Queiroz, L.P. 2009. Leguminosas da caatinga. Universidade Estadual de Feira de Santana, Feira de Santana. 467p.

Queiroz, L.P. \& Coradin, L. 1996. Biogeografia de Cratylia e áreas prioritárias para coleta. In: Pizarro, E.A. \& Coradin, L. (eds.). Potencial del género Cratylia como leguminosa forrajera. Centro Internacional de Agricultura Tropical (CIAT), Cali. Pp. 1-28.

Rico-Arce, M.L. 2007. A checklist and synopsis of American species of Acacia (Leguminosae: Mimosoideae). Comisión Nacional para el Conocimiento y Uso de la Biodiversidad (CONABIO), México. 207p.

Rodal, M.J.N. \& Nascimento, L.M. 2002. Levantamento florístico da floresta serrana da Reserva Biológica de Serra Negra, microrregião de Itaparica, Pernambuco. Brasil. Acta Botanica Brasilica 16: 481-500.

Rodal, M.J.N. \& Sales, M.F. 2007. Composição da flora vascular em um remanescente de floresta montana no semi-árido do nordeste do Brasil. Hoehnea 34: 433-446.

Rodal, M.J.N.; Sales, M.F.; Silva, M.J.S. \& Silva, A.G. 2005. Flora de um brejo de altitude na escarpa oriental do planalto da Borborema, PE, Brasil. Acta Botanica Brasílica 19: 843-858.

Rudd, V.E. 1958. A revision of the genus Chaetocalyx. Contributions from the National Herbarium 32: 207-245.

Rudd, V.E. 1972. Supplementary studies in Chaetocalyx (Leguminosae) including a new species from Brazil. Phytologia 24: 295-297.

Sartori, A.L.B. \& Tozzi, A.M.G.A. 1998. As espécies de Machaerium Pers. (Leguminosae - Papilionoideae - Dalbergieae) ocorrentes no estado de São Paulo. Revista Brasileira de Botânica 21: 211-246.

Sartori, A.L.B. 2000. Revisão taxonômica e estudos morfológicos de Myrocarpus Allemão, Myroxylon L. e Myrospermum Jacq. (Leguminosae Papilionoideae Sophoreae). Tese de Doutorado. Universidade Estadual de Campinas, Campinas. 268p

Scalon, V.R. 2007. Revisão Taxonômica do gênero Stryphnodendron Mart. (Leguminosae-Mimosoideae).
Tese de Doutorado. Universidade de São Paulo, São Paulo. 264p.

Silva, J.M. \& Casteleti, C.H.M. 2005. Estado da biodiversidade da Mata Atlântica brasileira. In: Galindo-Leal, C. \& Câmara, I.G. Mata Atlântica: biodiversidade, ameaças e perspectivas. Fundação SOS Mata Atlântica, Conservação Internacional, Belo Horizonte. Pp. 43-59.

Sinou, C.; Forest, F.; Lewis, G.P. \& Bruneau, A. 2009. The genus Bauhinia s.l. (Leguminosae): a phylogeny based on the plastid trnL-trnF region. Botany 87: 947-960.

Sousa, E.C.V. 2008. Distribuição e diversidade de Leguminosae em áreas de caatinga no município de Mirandiba-PE. Dissertação de Mestrado. Universidade Federal de Pernambuco, Recife. 163p.

Tozzi, A.M.G.A; Agostini, K. \& Sazima, M. 2005. A new species of Mucuna adans. (Leguminosae, Papilionoideae, Phaseoleae) from southeastern Brazil, with a key to Brazilian species. Taxon 54: 451-455.

Ulibarri, E.A. 1996. Sinopsis de Caesalpinia y Hoffmanseggia (Leguminosae-Caesalpinioideae) de Sudamérica. Darwiniana 34: 299-348.

Vanni, R. 2001. El género Desmodium (Leuminosae, Desmodieae) en Argentina. Darwiniana 39: 255- 285.

Vaz, A.M.S.F. 1993. Diversidade e conservação de lianas do gênero Bauhinia na amazônia brasileira. Acta Amazônica 23: 383-395.

Vaz, A.M.S.F. \& Tozzi, A.M.G.A. 2005. Sinopse de Bauhinia sect. Pauletia(Cav.) DC. (Leguminosae: Caesalpinioideae: Cercideae) no Brasil. Revista Brasileira de Botânica 28: 477-491.

Veloso, P.H.; Rangel Filho, A.L.R. \& Lima, J.C.A. 1991. Classificação da vegetação brasileira, adaptada a um sistema universal. IBGE, Rio de Janeiro. 124p.

Whittaker, R.H. 1975. Communities and ecosystems. Macmillan, New York. 385p.

Williams, R.J. \& Clements, R.J. 1990. Taxonomy of Centrosema. In: Schultze-Kraft, R. \& Clements, R.J. (eds.). Centrosema: biology, agronomy, and utilization. Centro Internacional de Agricultura Tropical (CIAT), Cali. Pp. 151-174.

Wunderlin, R.; Larsen, K. \& Larsen, S.S. 1981. Cercideae. In: Polhill, R.M. \& Raven, P.H. (eds.). Advances in legume systematics. Part 1. Royal Botanical Gardens, Kew. Pp. 107-116. 